\title{
The Psychology of Study Success in Universities
}

\section{Määttä, Kaarina}

Routledge

2018

Määttä , K \& Uusiautti , S 2018 , The Psychology of Study Success in Universities .

Routledge , London . https://doi.org/10.4324/9781315212104

http://hdl.handle.net/10138/312047

https://doi.org/10.4324/9781315212104

cc_by_nc_nd

publishedVersion

Downloaded from Helda, University of Helsinki institutional repository.

This is an electronic reprint of the original article.

This reprint may differ from the original in pagination and typographic detail.

Please cite the original version. 


\section{The Psychology of Study Success in Universities}

Kaarina Määttä and Satu Uusiautti 


\section{The Psychology of Study Success in Universities}

Universities around the world are under increasing pressure to maintain high levels of graduation and to make study processes as efficient as possible, with teachers and students struggling to meet the expectations placed upon them as a result. The Psychology of Study Success in Universities asks whether it is possible to meet these demands at the same time as protecting the well-being of students. Drawing on an extensive and detailed analysis of study success in universities in Finland, the authors of this thought-provoking work argue that universities should be more concerned with students' satisfaction and place greater weight on students' perceptions of the elements that enhance or hinder their success.

The book provides a multidimensional picture of the student- and teachingrelated factors that promote study success. Giving voice to graduate students, including those enrolled a $\mathrm{PhD}$ program, the authors look at the resources that students have at their disposal to establish what inspires and motivates the students, what slows them down, and what kinds of experiences students have of successful studies. Määttä and Uusiautti present a wealth of high-quality research showing that good teaching and successful study processes can be secured by immediate and caring interaction, flexible and student-centred teaching and supervision, and interdisciplinary collaboration between teachers.

The Psychology of Study Success in Universities is essential reading for academics, researchers, and postgraduate students in the fields of education and psychology, as well as for those interested in positive psychology, student well-being, and pedagogical studies.

Kaarina Määttä is a professor of educational psychology in the Faculty of Education at the University of Lapland, Finland. She is also vice rector of the University of Lapland.

Satu Uusiautti is a professor of education at the University of Lapland, Finland, and adjunct professor of educational psychology at the University of Helsinki, Finland. 

Taylor \& Francis http://taylorandfrancis.com 


\section{The Psychology of Study Success in Universities}

Kaarina Määttä and Satu Uusiautti 
First published 2018

by Routledge

2 Park Square, Milton Park, Abingdon, Oxon OXI4 4RN

and by Routledge

711 Third Avenue, New York, NY 10017

Routledge is an imprint of the Taylor \& Francis Group, an informa business

(C) 2018 Kaarina Määttä and Satu Uusiautti

The right of Kaarina Määttä and Satu Uusiautti to be identified as authors of this work has been asserted by them in accordance with sections 77 and 78 of the Copyright, Designs and Patents Act 1988.

The Open Access version of this book, available at www.taylorfrancis. com, has been made available under a Creative Commons AttributionNon Commercial-No Derivatives 4.0 license.

Trademark notice: Product or corporate names may be trademarks or registered trademarks, and are used only for identification and explanation without intent to infringe.

British Library Cataloguing-in-Publication Data

A catalogue record for this book is available from the British Library

Library of Congress Cataloging-in-Publication Data

A catalog record for this book has been requested

ISBN: 978-0-415-79196-0 (hbk)

ISBN: 978-1-315-21210-4 (ebk)

Typeset in Galliard

by Apex CoVantage, LLC 


\section{Contents}

List of Figures vi

Foreword vii

Contributors

Acknowledgements $\quad \mathrm{x}$

\section{PART 1}

Introduction

1.1 What is this book about? I

1.2 The expectation of success and prompt graduation 4

1.3 Introduction to the research behind this book 6

\section{PART 2}

Successful university students

2.1 The ideal study process and factors hindering it 19

2.2 PhD studies as described by doctoral students themselves 29

2.3 Students' resources in university studies 44

\section{PART 3}

Successful university teachers and teaching

3.1 Caring teacherhood in university education 71

3.2 Well-structured, positive teaching 76

3.3 Resources for the successful supervision of theses 90

3.4 Teacher collaboration and well-being as the success factor 98

\section{PART 4}

The importance and essence of study success

4.1 Success requires engagement and optimism 115

4.2 Love for learning as the way toward well-being and success 120

4.3 Study success as a process and outcome 122 


\section{List of Figures}

2.1 The ideal study process and factors hindering it 20

$\begin{array}{ll}2.2 \text { A master's garland } & 49\end{array}$

3.1 Emphases of teacher tutoring $\quad 80$

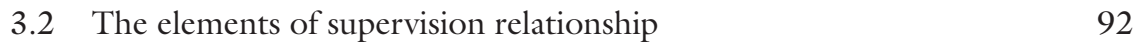

3.3 The supportive and protective factors of supervision 97

$\begin{array}{lll}4.1 & \text { Study success as a process and outcomes } & 125\end{array}$ 


\section{Foreword}

The Psychology of Study Success in Universities is a book inspired by our research about human flourishing in educational settings. We share the understanding of success as the manifestation of positive development that happens in positive contexts and institutions, supported by caring, warm educators who surround students. Positive development should be the number one goal in all educational levels, including universities. However, we also acknowledge the concern of everincreasing efficiency and productivity pressures, especially in the higher education level. Our genuine wish is to contribute a viewpoint that shows how by focusing on student well-being and flourishing, it is possible to enhance their study success and the success of the university, too. These two objectives do not exclude each other but can coexist.

Our viewpoint in this book is based in Finland, where we both work at the University of Lapland. It is the northernmost university in the European Union, located on the Arctic Circle. We are happy about the opportunities this small but vivid university offers to people living in the area and across the Finland. But to stay as vivid as it is, it needs successful students. Research that is introduced in this book is based on studies among university students of the University of Lapland. Although the sets of data are not large in quantitative sense, they provide a multidimensional and thorough description of how students themselves - across disciplines and study programs - perceive the prerequisites of their study success. We are thankful to all students who have participated in our research and helped us understand the student perspective and develop teaching and supervision at the university. We believe that these lessons give insights to other higher education institutions, too, nationally and internationally.

Since we both work at the Department of Education, we wanted to include in this book perspectives on caring teacherhood and good teaching and supervision practices in universities. We have studied caring teacherhood from various perspectives with our colleagues in early childhood education, basic education, special education, upper secondary education, and higher education. In addition, we have extensive experience on supervision of doctoral theses, based on which we wanted to include findings about best supervision practices as well as $\mathrm{PhD}$ students' experiences of the doctoral research process.

Our purpose has been to compile a compact, research-based package to contribute to discussion about study success in universities for researchers, teachers, 


\section{viii Foreword}

educators, professors, and other academics worldwide. This kind of book will be interesting for postgraduate students, too, who are performing their doctoral studies; they are future researchers in the field. First and foremost, we hope that this kind of book can support university teachers and professors in their work.

In Rovaniemi, on the Arctic Circle and on Valentine's Day, February 14, 2017. 


\section{Contributors}

Kaarina Määttä, PhD, is a professor of educational psychology and vice rector, University of Lapland

Professor Määttä has a long career at the University of Lapland (since 1977). Her doctoral dissertation addressed teachers' professional development, and she has actively developed university teaching and education as well as supervision. In addition, she has studied human relationships and love and its various forms based on thousands of Finnish people's experiences. She has written numerous books and international articles about the theme. Her latest personal research interests have focused on love, attachment, and social relationships during human beings' lifespans, on supervising the doctoral thesis and process of that as well as on positive psychology and human strengths. Her latest publications include Many Faces of Love (authored by. K. Määttä and S. Uusiautti, Sense Publishers, 2013), Obsessed with Doctoral Theses (edited by K. Määttä, Sense Publishers, 2012), Early Child Care and Education in Finland (edited by K. Määttä and S. Uusiautti, Routledge, 2013), and Time for Health Education (edited by K. Määttä \& S. Uusiautti, Peter Lang, 2014).

Satu Uusiautti, PhD, is a professor of education, University of Lapland, adjunct professor, University of Helsinki, Finland

In her doctoral thesis (2008, at the University of Lapland), she studied success at work as a manifestation of well-being. Since that, she has continued with the theme and expanded it toward love, leadership, and overall human well-being. Her personal research interests are in positive psychology, human strengths, and success and positive development. Her latest publications include The Psychology of Becoming a Successful Worker. Research on the changing nature of achievement at work (authored by S. Uusiautti and K. Määttä, 2015, Routledge), Critical Eye on Education (edited by S. Uusiautti \& K. Määttä, 2015, United Press Global), and Sámi Education (authored by P. Keskitalo, K. Määttä, and S. Uusiautti, Peter Lang, 2013). 


\section{Acknowledgements}

This book was inspired by and is partly based on the following articles:

Määttä, K. (2011). The dissertation process described by doctoral students in Finland. E-International Journal of Educational Research, 2(1), 66-80.

Määtä, K., \& Uusiautti, S. (2012). How to enhance the smoothness of university students' study paths? International Journal of Research Studies in Education, I(1), $47-60$.

Määttä, K., \& Uusiautti, S. (2016). Students' perceptions of factors slowing down their study progress: the case of University of Lapland. Problems of Education in the 21 st Century, 72, 65-75.

Määttä, K., \& Uusiautti, S. (2016). The resources of good supervision. European Scientific Journal, April/2016/Special Edition, 180-191.

Määttä, K., \& Uusiautti, S. (2016). What are successful fast-graduating masters made of? International Journal of Arts and Sciences, 9(3), 1-12.

Määttä, K., Uusiautti, S., \& Määttä, M. (2014). A story of an ideal study process at the University of Lapland, Finland. Global Journal of Human Social Sciences, 14(1), 83-89.

Määttä, K., Uusiautti, S., \& Määttä, M. (2014). Doctoral dissertation as action at one's limits - what are the individual and context-bound strengths of top performances. International Journal of Arts and Sciences, 7(6), 587-605.

Uusiautti, S., \& Määttä, K. (2013). Enhancing university students' study success through caring leadership. European Scientific Journal, SE2/2013, 398-407. Retrieved from www.eujournal.org/index.php/esj/article/view/1352

Uusiautti, S., \& Määttä, K. (2014). I am no longer alone - how do university students perceive their possibilities of social media. International Journal of Adolescence and Youth, 19(3), 293-305. doi:10.1080/02673843.2014.919600

Uusiautti, S., \& Määttä, K. (2014). If it is ok that your mom can see it, you can publish it - on the suitable behavior in the social media according to Finnish university students' opinions. British Journal of Education, Society e Behavioral Science, 4(9), 1184-1202.

Uusiautti, S., \& Määttä, K. (2015). Engagement and hope as factors behind success at work. Journal of Studies in Education, 5(2), 106-118.

Uusiautti, S., \& Määttä, K. (2016). The multidimensional phenomenon of study success in higher education - a head start to success at work? Journal of Studies in Education, 6(3), 1-20. doi:10.5296/jse.v6i3.9540 


\section{Part 1}

\section{Introduction}

\subsection{What is this book about?}

Finland and the Finnish school system have aroused worldwide interest since Finnish students' success in international student comparisons (e.g., Programme for International Student Assessment, PISA) (Lavonen \& Laaksonen, 2009; Välijärvi, 2014; Välijärvi et al., 2007). One reason behind the success is the Finnish research-based teacher training (e.g., Jakku-Sihvonen \& Niemi, 2006) and continuous interest in students' success and well-being (e.g., Howell, 2009; Salmela \& Uusiautti, 2015). Recently, Finnish university education was also noticed in the news when comparing graduates from different countries (OECD, 2016). It turned out that when, for example, comparing graduates' literacy skills, none of the countries (e.g., Japan and Finland) in the top places made much of an appearance in conventional university rankings (see BBC News, October 20, 2016).

Finland's education system is based on the idea of equal access to every level of education (e.g., Rinne, Kivirauma, \& Simola, 2002). Finnish university education is free for every Finnish student who passes the application tests. Basically, the same success expectations concern university students, too, but at the university level, the changing world has also changed the elements of success because prompt study processes and high levels of graduation have become a lifeline for universities not only in Finland but also across the world. Teachers and students have to struggle between these demands and expectations amongst which highquality learning and profound studying can even take a backseat (cf., FitzSimmons, 2014). Educators have asked how to have students pass courses quicker and more efficiently while still taking care of their well-being. This book provides research-based answers to these questions.

According to positive psychological understanding, satisfaction and well-being are important factors of efficient graduation and quality outcomes in studies regardless of education level (Langford et al., 2014; Pajares, 2001; Seligman et al., 2009). Therefore, universities should be worried about students' satisfaction and pay attention to their perceptions of the elements in education that enhance or hinder their study success. These phenomena are discussed in The Psychology of Study Success in Universities. The book provides a multidimensional picture of 


\section{Introduction}

the student-related factors and teaching that may best enhance study success. The book gives voice to both graduate students and PhD students from Finland and compares findings in the light of international well-being theories and studies on university-level study success.

By 'success in studies', we refer to a two-dimensional process that consists of the fluent study process during which students flourish, study in a balanced manner, get support, and show high levels of well-being and of successful study outcomes, that is, good grades, fast graduation, and satisfaction with studies. The theoretical foundation of the book is based on positive psychological theories and research, and thus the book offers quite a wide introduction of international studies in the field. The themes in the book are also discussed from the practical perspective through various student data from Finland. The purpose is to provide an extensive analysis on study success in universities for researchers, teachers, educators, professors, and other academics primarily. This kind of book will be interesting for postgraduate students, too, who are performing their doctoral studies; they are future researchers in the field.

The Psychology of Study Success in Universities focuses first on students and their resources - what inspires them in studies, what slows down their study processes, and what kinds of experiences they have on successful studies. Similarly, success in university studies sets great expectations to university teachers' and lecturers' teaching and supervision work. However, teaching in universities is quite concrete, and students' hopes are very practical as well. Good teaching and successful study processes are secured by immediate and caring interaction, flexible and student-centred teaching and supervision, and interdisciplinary collaboration among teachers. Finally, the book describes study success as a multidimensional concept that covers successful outcomes and a successful study process as well. The latter refers to important well-being elements in the academic community that are frequently put aside when outlining new plans of efficiency.

Although the research data the book is based on have been obtained in Finland, the findings and general discussion are relevant to researchers, teachers, and students everywhere. Study success is important, and the fundamental resources from the positive psychological viewpoint are somewhat universal. However, the book is interesting also because student mobility is greater than ever, and universities get more and more students from, for example, Africa, Asia, India, and South America. These students, too, need information about the nature of university studies in general, including their demandingness and effort. It is important to provide new research-based, innovative ideas of how to be successful - not just in undergraduate but also in doctoral studies.

The book is divided into parts with approximately three chapters. The chapters following the Introduction provide their own perspective on the phenomenon of study success. They are wide and profound explorations into the success factors first from the students' perspective followed by teaching and teachers' perspective. The final chapter then illustrates the phenomenon in general.

The Introduction introduces the current productivity expectations of graduations and study processes in universities today. The introductory part also provides 
a discussion of the book's distinctive contribution. In addition, it highlights the demands sets on university teaching, also providing the teachers' viewpoint. Because the purpose of the book is to discuss success in studies, the Introduction also includes the basic definition of positive psychological approach in the book. How is well-being in students and teachers connected with success, and why is it important to discuss them simultaneously? In addition, the Introduction contains introductions of the studies, data, and data analyses on which the book is based.

The second part discusses study success from the student perspective. It answers questions of what successful, fast-graduating masters are made of, how students perceive the smoothness of their study processes, and what kinds of factors may slow down their progress and hinder success in studies. To develop university education, it is crucial to hear students' voices and know what exactly they appreciate and, on the other hand, would like to develop in university studies. The first chapter highlights the success factors in masters' studies, and the second chapter complements the discussion with $\mathrm{PhD}$ students' viewpoints. Finally, the third chapter summarises special resources that university students need during their studies to get good grades and maintain their personal well-being.

The third part introduces success in university studies from teachers' viewpoints. It continues the theme from the Introduction by explaining how the approach of caring teacherhood may enhance both students' study success and teachers' well-being. The first chapter discusses the elements of caring teacherhood in general. The second chapter introduces viewpoints to positive teaching as well as caring online teaching practices. After that, the resources of supervision of masters' and $\mathrm{PhD}$ theses by focusing on the description of the nodes and strides of successful supervision are introduced. How to provide critical but encouraging feedback during the supervision process and how to support students with diverging motivation to complete their theses successfully? Among others, these are the questions this part answers. Finally, the last chapter in Part 3 points out the invaluable resource of teachers' and professors' collaboration, caring atmosphere, and mutual support that make the cornerstone of a healthy academic community with high levels of well-being - and that reflects on the students' well-being as well.

The fourth part concludes the book by highlighting the key points that connect success and well-being in university studies. The first chapter explains the meaning of engagement and optimism - how they both are needed to persevere in studies and to reach the valuable achievement of graduation and how their emergence in students can be supported by the university community. The second chapter continues by discussing the meaning of love for learning and how this positive state or attitude to studies can become not only an important success factor but also enhance well-being. The last chapter introduces the concept of study success as a two-dimensional phenomenon. On the one hand, success is about the outcomes - passing courses, high grades, and finally graduation - but on the other hand, and as the earlier parts of the book have shown, it is also about the study process. The final argument is, therefore, that there cannot be true success in studies without a smooth, caring study process in which well-being 


\section{Introduction}

is appreciated as much as the numeric goals of the student; teachers; and, in the end, the university as well.

\subsection{The expectation of success and prompt graduation}

Today, efficiency requirements and productivity expectations have a great influence on studies in colleges and universities. More and more doctors are graduating, and basic degrees, such as master's degrees, should be performed faster. Universities are expected to take action to enhance fast graduation (Carter \& House II, 2010; Ensigna, 2010). Apparently, the governments would like to see the youth applying for studies fast, making their decisions about study places quickly, and performing their studies promptly and thus entering the work market as young as possible (Pennington, 2004).

On the other hand, requirements of more and more efficient use of teaching resources and large study groups can make university studies more difficult (Kokkelenberg, Dillon, \& Christy, 2008). Resources should be secured and calculated so that students can design their own individualized study plans. Or is the number of students the deciding factor (Bedard \& Kuhn, 2008)?

How can the smoothness of university studies be enhanced from the students' point of view? University teachers and curricula have an important role in this process but, eventually, the demands are targeted at students themselves. They should be able to finish their studies quickly yet with high scores.

Universities do have various programs to support students' progress (Glocker, 2011; Groen, Jakubson, Ehrenberg, Condie, \& Liu, 2008; Nutting, 2014). The efficiency of these programs has also been evaluated in studies (Ward \& Vargas, 2011). Indeed, more attention has been paid to, for example, student tutoring (Elbaum, Vaughn, Tejero Hughes, \& Watson Moody, 2000; Graesser, Chipman, Haynes, \& Olney, 2005; Määttä, 2012, 2015). Although university lecturers' and professors' work focuses on research, from the students' perspective, quality teaching that is based on research is fundamental to the success of their study paths (Parker, 2008). Likewise, teachers learn, too, constantly when teaching and lecturing and supporting students' studies (Gibbs \& Coffey, 2004). Actually, teachers may have the determining role in the smoothness of university studies (Bambrick-Santoya, 2014; Bell \& Robinson, 2004; Lee \& Cho, 2014; Uusiautti \& Määttä, 2013a).

Numerous studies have outlined the features of teaching that enhance the smoothness of students' studies the best (DePillis \& Johnson, 2015; Uusiautti \& Määttä, 2013b; Äärelä, Määttä, \& Uusiautti, 2016). Research has focused on, for example, the importance of a positive study atmosphere (Shahidi \& Sobhani, 2015), the level of face-to-face teaching (Symonds, 2014), the supervision of master's theses (Chongyi, 2004), the significance of the first study year (Keup \& Barefoot, 2005; Schellenberg \& Bailis, 2015), and the level of interaction between the teaching personnel and students (Bowman \& Akcaoglu, 2014; Määttä, 2015). Study evaluation practices are also important and can promote learning and increase motivation if evaluations are constructive (González, Jareño, \& López, 2015). 
Furthermore, peer evaluations and peer support can enhance studies (e.g., Hamer, Purchase, Luxton-Reilly, \& Denny, 2015; Ludemann \& McMakin, 2014; Wierstra, Kanselaar, Van Der Linden, \& Lodeewijks, 1999; Topping, 1998) when we realize that the criticism and evaluations do not have to be crippling (Woodward-Kron, 2002). Writing skills development is crucial for study success (Butler \& Britt, 2011; Cho, Schunn, \& Charney, 2006; Määttä, 2012). Naturally, multiform teaching and digitalization have provided new means to make studying even more efficient (e.g., Blocher, De Montes, Willis, \& Tucker, 2002; Gillani \& Eynon, 2014; Hannan, 2005; Howland \& Wedman, 2004; Ramos et al., 2015). In all, it is important to make teaching more varied and multiform (Cheng, 2011).

Often, students are expected to perform more and better, which means that the idea of good learning can be shadowed by criticism (Stellmack, Keenan, Sandidge, Sippl, \& Konheim-Kalkstein, 2012). Students' motivation becomes tested (Reiss, 2012), which can result in their dropping out of education (Cortes, Mostert, \& Els, 2014; Stratton, O’Toole, \& Wetzel, 2008) or in fatigue (Galbraith \& Merrill, 2015; Olwage \& Mostert, 2014).

Indeed, good teaching and ways of developing teaching have been studied widely. Still, one may ask whether good teaching is the precondition of good learning. Is good teaching enough (Helmke \& Schrader, 1988)? Or is it more important to know how students perceive their studies and education and how they understand the goals and reality of their own studies?

Students want to gather study points and grades and advance in their studies. Good study success reflects to students' well-being and health, too (Eide \& Showalter, 2011; Uusiautti \& Määttä, 2015b, 2016). Well-being makes study processes smoother (Rauscher \& Elliott III, 2014). However, if studies become prolonged or overwhelming, students' quality of life decreases (Cowan, 2011; Hansen \& Lang, 2011). Thus, everyone dealing with university teaching shares the goal of finishing studies and graduating promptly. And yet, study processes can become long and graduation postponed.

One reason for prolonged studies is that students want to study 'everything' in other words, extensively - and thus guarantee their employment (Dolton \& Silles, 2008; Hartog, 2000). For example, in Finland, although the employment situation among university graduates is relatively good, their unemployment has increased (Työ- ja elinkeinoministeriö, 2016). Yet there are also other reasons for overeducation, which have also been studied from numerous viewpoints (Budría \& Moro-Egido, 2014; Sánchez-Sánchez \& McGuinness, 2015; Tarvid, 2013).

Often study progress becomes hindered by financial problems (Reed \& Hurd, 2014), and parents cannot always help students financially (Dockery, Seymour, \& Koshy, 2016). Again, students may have other priorities in life, too, than studies and graduation (Chesser, 2015).

It is obvious that students' study skills and attitudes influence their way of studying and opportunities of succeeding (Määttä, Uusiautti, \& Määttä, 2016). Personality features have their own influence (Duff, Boyle, Dunleavy, \& Ferguson, 2004). Previous study success (Busato, Prins, Elshout, \& Hamaker, 2000), even 


\section{Introduction}

experiences in elementary school, have their own influence on university studies (Hébert, 1993). Students' expectations and understanding about the length and demands of studies can be too high or unrealistic (Brunello \& Winter-Ebmer, $2003)$.

In all, study success is a sum of several factors (Määttä, Uusiautti, \& Määttä, 2016). A push for the renewal of university teaching has been great for a long time already (Ebert-May et al., 2015), but the change is slow, and traditions stick hard (Brownell \& Tanner, 2012; Ebert-May et al., 2011). Despite the long call for reforms (Frayer, 1999), it is strange that new ideas and methods are put in practice this slowly (Tagg, 2012). However, some findings suggest that universities have renewed considerably (Gormally, Evans, \& Brickman, 2014). However, the pressure is great, and not all changes can be realized at once and quickly (Gregory \& Lodge, 2015). In the middle of efficiency and quality pressures, resources for teaching and research are limited (Xuereb, 2015). How can these resources be used in an efficient way that benefits not only the students but universities, too?

\subsection{Introduction to the research behind this book}

The book is based on the following sets of data and methods. The various sets of data complement each other, providing multidimensional viewpoints to various elements of study success. Because the data are mainly qualitative in nature, they offer rich descriptions of student experiences and perceptions that are analyzed in the light of previous international studies. Although the sets of data are quite small and come only from one university, they introduce quite different perspectives for university studies and cover various phases of studies all the way from master's education to $\mathrm{PhD}$ studies. Eventually, the phenomenon of study success is somewhat universal by nature.

\section{Data 1}

The data collection happened via an internet-based questionnaire called Webropol in May 2014. The questionnaire was sent to 506 students who had registered as present students for their first study year at the University of Lapland. Of them, 186 replied. Those who participated in the study were mostly women: $74 \%$ were women, and $23 \%$ men ( $3 \%$ of students, $n=5$, did not report their genders). The distribution resembles the actual distribution of women and men at the University of Lapland. Of the participants of this study, $67 \%$ were younger than 24 years old; $18 \%$ were 25 to 29 years old; $4 \%$ were 30 to 34 years old; and $6 \%$ were older than 40 years old. The median of students at the University of Lapland is 27 years.

The participants of this study also represented the four departments of the university relatively well. Forty-four students $(23.7 \%)$ were from the department of education, 49 students $(26.3 \%)$ were from the department of law, 27 students (15.5\%) were from the department of arts, and 66 students $(35.5 \%)$ were from the department of social sciences. 
The data were analyzed with a content analysis method that was qualitative data-based analysis (Kolbe \& Burnett, 1991). First, the students' responses were categorized into rough categories that formed the initial division into items describing hindrances of study progress and, on the other hand, their perceptions of study success and factors enhancing it. Eventually, seven main categories could be distinguished that form the most important factors hindering smooth progress in studies according to students' perceptions. Eight main categories could be distinguished that outlined the main factors the students mentioned when describing their study success.

When it comes to reliability in studies like this, some basic issues can be evaluated. First, the reliability of the data collection method must be assessed. In this research, the internet-based questionnaire was considered the most suitable way of contacting students: they could be easily reached via email. Another advantage was that they could fill the questionnaire whenever it was the most convenient for them. However, this always causes some disadvantages, too: many respondents may easily forget or ignore the request to participate in the research, or answers can remain short and superficial. In addition, the researcher cannot be certain who has actually answered the questions (although it is highly unlikely that someone else could answer in behalf of a student) and how, for example, the circumstances of the answering moment (e.g., mood, motivation, satisfaction of studies or latest courses, or other factors in students' personal lives) have influenced the students' answers. The quality of research is, therefore, mainly based on the quality of data - in this case, the content of answers (Couper, Kapteyn, Schonlau, \& Winter, 2007). This evaluation showed that the students had contemplated profoundly their study experiences and written about their difficulties and other adversities in an open manner. For example, their ability to notice shortcomings in their study skills showed that they did not just blame teachers or unpleasant teaching arrangements for the hindrances they had faced.

In addition, the reliability of this research was pursued to strengthen with collaboration of two researchers (Wray, Markovic, \& Manderson, 2007). This enhanced the analysis by making sure that interpretations were not just based on one person's preconceptions but on data. Yet it is still possible that some other researcher or research group could categorize or interpret the data differently. However, for the purposes of the research, the analysis showed what the crucial factors that hinder smooth study progress in students' opinion are. The categories are therefore strictly based on the frequencies of occurrence in the data.

This data set was used as the part of discussion in Chapters 2.1, 4.2, and 4.3.

\section{Data 2}

This study focused on $\mathrm{PhD}$ students who had either started their doctoral research or had already graduated as doctors from 2005 to 2008. They were asked to write about their dissertation processes. Altogether, $25 \mathrm{PhD}$ students and graduates provided their narratives. Their narratives made up a data set, which was complemented with email conversations between the supervisor and the PhD students. The email data consisted of hundreds of messages sent over the years during the 


\section{Introduction}

dissertation processes. Thus, the aforementioned two sets of data provided multidimensional viewpoints to the dissertation process; on the one hand, it revealed the supervisees' experiences and perceptions of the top performance, and, on the other hand, it sheds light on the supervisor's role and work during the process.

The data have been analyzed with a theory-led content analysis (see also Mayring, 2000). The main themes have been derived from our classification of human resources (see Määttä \& Uusiautti, 2012): emotional, social, cognitive, and functional resources. In addition, we have referred to Mihaly Csikszentmihalyi's (2008) definition of the elements of the optimal experience, flow. Data regarding supervision of doctoral theses were analyzed in the light of caring teacherhood and love-based leadership (Theilheimer, 1991; Uusiautti \& Määttä, $2013 \mathrm{c}$ ). However, because the two sets of data provided such a profound and multidimensional viewpoint to the dissertation process, the analysis has also databound features, which means that we have given space to features emerging from the data.

When it comes to the reliability of the research, we have every reason to believe that the rich data have provided a profound and trustworthy illustration about the dissertation process as a manifestation of a top performance. To ensure the confirmability of the research, it is important to demonstrate that findings emerge from the data and not from researchers' own predispositions (Shenton, 2004); therefore, the doctoral students' voices are included in the parts of this book widely.

This data set was used as the part of discussion in Chapters 2.2, 3.1, 3.2, and 4.1 .

\section{Data 3}

The data were collected in the fall of 2015 at the University of Lapland. The data collection took place during a so-called master's workshop in which 110 students from different departments performing master's studies participated. Alumni presented their viewpoints and experiences of the groups of studies and about the different phases of studies and their coping strategies.

The participants' viewpoints were analyzed through qualitative content analysis (see e.g., Mayring, 2000) by categorizing the participants' answers into databased themes and categories. Eventually, 12 different themes were found that formed the results. The themes describe the participants' viewpoints of what the necessary elements of successful master's and graduation processes are.

In qualitative studies like this one, reliability can be evaluated by assessing the quality of data and its truthfulness (e.g., Creswell, 2009). These data were obtained in a workshop-like event where soon-to-be masters and already graduated masters, alumni, were gathered to discuss their study processes - the hindrances, adversities, and the positive experiences during them. The purpose was to bring out the students' voices and let them describe their experiences openly so that the data would serve not only to support the development of a caring 
university community (Uusiautti \& Määttä, 2016) but also to support students' fluent study paths (Määttä, Uusiautti, \& Määttä, 2016). The data were rich and abundant. The participants described openly their experiences and drew a multidimensional picture of what is required from students aiming at the completion of master's degrees. When evaluating the analysis, it is worth noticing that the researchers in this study both teach at the university and, therefore, it was important to make sure that the interpretations would not be skewed by the teaching experiences or even stubborn ideas of good teaching and good university students (see also Uusiautti \& Määttä, 2015a). Researchers' careful self-reflection was important in this study because interpreting the results is the researchers' privilege and responsibility (Fontana \& Frey, 2005). Sticking to the students' descriptions and voices and genuinely wishing to bring out viewpoints that might help developing university education were considered to enhance the reliability of interpretations in this study.

This data set was used as the part of discussion in Chapters 2.3 and 4.3.

\section{Data 4}

The study was conducted on 23 to 25 September 2013 among students at the University of Lapland, Finland, in an educational psychology course titled 'The Basics of Learning and Developmental Psychology' (5 ECTS). The course lecturer asked the participants to fill out a questionnaire about their relationship with social media. Answering was voluntary and anonymous, so it did not influence, for example, the students' grading.

Of the 140 students taking the course, 90 students participated in the research by returning the questionnaire, a relatively good participation rate of $64 \%$. Only seven respondents were men $(7.8 \%)$, and 83 were women $(92.2 \%)$. This uneven gender balance lies in the fact that students of education and educational psychology are mostly women. However, because the purpose of the study was not to discover any gender-specific differences in the use of social media but only students' social network services (SNS) behavior in general, the data were considered suitable and are not analyzed in terms of gender.

The questionnaire included both structured questions and open-ended questions. The structured questions were for collecting background information only, and the answers provided for the open-ended questions formed the actual data. The answers were analyzed through qualitative content analysis in the light of the research questions (see e.g., Mayring, 2000). The questions focused on four core areas: (1) the students' opinions on social media and its importance, (2) their behavior on social media, (3) rules of using social media and agreements between friends and family members, and (4) the usability of social media.

When it comes to the reliability of the study, the data were considered suitable because almost everyone used SNSs and were at least familiar with them. The answers given in the questionnaire did not illustrate just the participants' ideas; they were also based on their practical experiences in SNSs. Relatively many of 
the participants described their relationship with social media as natural; a SNS or SNSs had become a part of their everyday lives, and the classification between 'the real life' and 'SNS life' had become vague. Thus, the data provided a good way of analyzing the benefits of social media according to these university students' points of view.

This data set was used as the part of discussion mainly in Chapter 2.3.

\section{Data 5}

The data were collected in the fall 2016 among university students of educational psychology. They were asked to fill out an online questionnaire about online teaching and learning environments. Of the 101 students 34 (29 women and 5 men, aged 20-52 years; mean age, 29.9 years) participated in the study. Because the course was open to graduate students of the University of Lapland and students from the Open University at the University of Lapland, the mean age of participants was relatively high. However, the number of women and men represented the overall situation among students of educational psychology well. All participants had previous experiences of online teaching; thus, they could be considered suitable participants in the study.

The data collection method was a qualitative questionnaire that consisted of five main questions. The questionnaire was an online questionnaire (provided by Webropol) to which the participants received a link and request to participate from the teacher of the course. They received the link via email and from an online study environment called 'Optima'. Students could choose whether they wanted to participate or not, and they could answer the questionnaire anonymously. Their personal details were not asked at any point in the data collection procedure. The questionnaire presented one question at a time, and the participants had to answer the question before they could see the next question. However, it was possible to quit or return to the questionnaire later.

The participants were encouraged to write freely about their experiences, perceptions, and opinions about online teaching. The concept of online teaching was not defined or specified, but the students could describe in what kinds of courses they had participated and how they were arranged. Based on the descriptions, most of the students had participated in courses with online lectures that could be watched from their own computer, laptop, tablet, or smartphone. Some courses had included short tasks (e.g., writing tasks) and other independent studies (e.g., familiarization with course literature). Some courses had online group work, too. Basically, online teaching was online lecturing that could but did not necessarily include interactive tasks during lessons.

After background questions (age, experience with online teaching), the participants were asked to describe positive learning experiences in online teaching. If they had any, they were prompted to describe how the course was designed, what happened in the course, what features made learning positive, and so on. The second question was focused on the negative experiences of online teaching, and students were asked what features led to negative experiences. Third, they were asked 
to describe how they would develop online teaching based on their own experiences. The fourth theme covered interaction in online teaching with (1) the teacher and (2) other students. The students were asked to describe what the interaction is like in online teaching, and these questions did not include any implications to the nature of interaction (e.g., positive or negative). The last main question asked what an ideal online teaching and learning environment would be like. The students could describe it based on their own experiences, or they could imagine one and describe it. They were prompted with additional questions such as what makes the teaching and learning environment positive and what makes it meaningful to them. Finally, the students could write freely about their experiences or thoughts if they wanted to add something they considered important about the theme.

The purpose was to obtain information about students' experiences of online teaching. In addition, their answers revealed how they perceived the teacher's action in such a learning environment. Indeed, the data were rich, and students described in detail and in an honest manner what they had found positive and negative and how they perceived interaction in online teaching.

The data were analyzed with qualitative content analyzing method by categorizing items from the data and forming data-based categories, such as various elements of positive learning experiences. Although the number of participants remained relatively low, the data appeared rich and relevant for the purposes of the research. It brought out students' practical experiences, and based on them, it is possible to develop online teaching methods and increase meaningful study experiences among students in online courses.

This data set was used especially in Chapter 3.2.

\section{References}

Äärelä, T., Määttä, K., \& Uusiautti, S. (2016). Caring teachers' ten dos. 'For the teacher, they might be just small things, but for the student they mean the world'. International Forum of Teaching and Studies, 12(1), 10-20.

Bambrick-Santoya, P. (2014). Make students college-ready in high school: to increase college persistence and graduation, we must get better at teaching high school students the on-the-ground skills they will need to be successful in college. Phi Delta Kappan, 95(5), 72.

$B B C$. (2016, October 20). Who really has the cleverest students? Retrieved from www.bbc.com/news/business-37649892 ?ocid=socialflow_facebook\&ns_ mchannel=social\&ns_campaign=bbcnews\&ns_source=facebook

Bedard, K., \& Kuhn, P. (2008). Where class size really matters: Class size and student ratings of instructor effectiveness. Economics of Education Review, 27(3), 253-265. doi:10.1016/j.econedurev.2006.08.007

Bell, C. L., \& Robinson, N. G. (2004). The successful student-teaching experience: Thoughts from the ivory tower: Student teachers can successfully navigate this important stage in their career with the help of their college supervisors and cooperating teachers. Music Educators Journal, 91(1), 39-43.

Blocher, J. M., De Montes, L. S., Willis, E. M., \& Tucker, G. (2002). Online learning: Examining the successful student profile. Journal of Interactive Online Learning, 1(2), 1-12. 


\section{Introduction}

Bowman, N. D., \& Akcaoglu, M. (2014). 'I see smart people!' Using Facebook to supplement cognitive and affective learning in the university mass lecture. The Internet and Higher Education, 23, 1-8.

Brownell, S. E., \& Tanner, K. D. (2012). Barriers to faculty pedagogical change: Lack of training, time, incentives, and. . tensions with professional identity? CBE-Life Sciences Education, 11(4), 339-346. doi:10.1187/cbe.12-09-0163

Brunello, G., \& Winter-Ebmer, R. (2003). Why do students expect to stay longer in college? Evidence from Europe. Economics Letters, 80(2), 247-253. doi:10.1016/ S0165-1765(03)00086-7

Budría, S., \& Moro-Egido, A. (2014). Overqualification, skill mismatches and wages in private sector employment in Europe. Technological and Economic Development of Economy, 20(3), 457-483.

Busato, V. V., Prins, F. J., Elshout, J. J., \& Hamaker, C. (2000). Intellectual ability, learning style, personality, achievement motivation and academic success of psychology students in higher education. Personality and Individual Differences, 29(6), 1057-1068. doi; 10.1016/S0191-8869(99)00253-6

Butler, J. A., \& Britt, M. A. (2011). Investigating instruction for improving revision of argumentative essays. Written Communication, 28(1), 70-96. doi:10.1177/0741088310387891

Carter, M., \& House II, D. L. (2010). Fast forward: From dropout to graduation and beyond. Community College Journal of Research and Practice, 34(11), 939-941.

Cheng, D. A. (2011). Effects of class size on alternative educational outcomes across disciplines. Economics of Education Review, 30(5), 980-990. doi:10.1016/j. econedurev.2011.04.009

Chesser, S. (2015). Intersection of family, work and leisure during academic training. Annals of Leisure Research, 18(3), 308-322.

Cho, K., Schunn, C. D., \& Charney, D. (2006). Commenting on writing typology and perceived helpfulness of comments from novice peer reviewers and subject matter experts. Written Communication, 23(3), 260-294. doi:10.1177/0741088306289261

Chongyi, W. (2004). Strengthening the supervision of graduation thesis writing to improve students' integrated quality-some thoughts about graduation thesis writing. Foreign Language Education, 6, 10-17.

Cortes, K., Mostert, K., \& Els, C. (2014). Examining significant predictors of students' intention to drop out. Journal of Psychology in Africa, 24(2), 179-185. doi: $10.1080 / 14330237.2014 .903070$

Couper, M. P., Kapteyn, A., Schonlau, M., \& Winter, J. (2007). Noncoverage and nonresponse in an Internet survey. Social Science Research, 36(1), 131-148. doi:10.1016/j.ssresearch.2005.10.002

Cowan, B. W. (2011). Forward-thinking teens: The effects of college costs on adolescent risky behavior. Economics of Education Review, 30(5), 813-825. doi:10.1016/j. econedurev.2011.04.006

Creswell, J. W. (2009). Research design: Qualitative, quantitative, and mixed methods approaches. Thousand Oaks, CA: Sage.

Csikszentmihalyi, M. (2008). Finding flow: The psychology of engagement with everydaylife. New York, NY: Basic Books.

DePillis, E., \& Johnson, G. (2015). First, do no harm: Effective, ineffective and counterproductive teaching methods. Journal of Higher Education Theory and Practice, 15(1), 58 . 
Dockery, A. M., Seymour, R., \& Koshy, P. (2016). Promoting low socio-economic participation in higher education: A comparison of area-based and individual measures. Studies in Higher Education, 41(9), 1692-1714. doi:10.1080/03075079.2 015.1020777

Dolton, P. J., \& Silles, M. A. (2008). The effects of over-education on earnings in the graduate labour market. Economics of Education Review, 27(2), 125-139. doi:10.1 080/03075079.2015.1020777.

Duff, A., Boyle, E., Dunleavy, K., \& Ferguson, J. (2004). The relationship between personality, approach to learning and academic performance. Personality and Individual Differences, 36(8), 1907-1920. doi:10.106/j.paid.2003.08.020.

Ebert-May, D., Derting, T. L., Henkel, T. P., Maher, J. M., Momsen, J. L., Arnold, B., \& Passmore, H. A. (2015). Breaking the cycle: Future faculty begin teaching with learner-centered strategies after professional development. CBE-Life Sciences Education, 14(2), ar22. doi:10.1187/cbe.14-12-0222

Ebert-May, D., Derting, T. L., Hodder, J., Momsen, J. L., Long, T. M., \& Jardeleza, S. E. (2011). What we say is not what we do: Effective evaluation of faculty professional development programs. BioScience, 61(7), 550-558.

Eide, E. R., \& Showalter, M. H. (2011). Estimating the relation between health and education: What do we know and what do we need to know? Economics of Education Review, 30(5), 778-791. doi:10.1016/j.econedurev.2011.03.009

Elbaum, B., Vaughn, S., Tejero Hughes, M., \& Watson Moody, S. (2000). How effective are one-to-one tutoring programs in reading for elementary students at risk for reading failure? A meta-analysis of the intervention research. Journal of Educational Psychology, 92(4), 605.

Ensigna, R. L. (2010). Fast gainers: 4 ways that colleges have raised graduation rates. Chronicle of Higher Education, 57(16), Al5.

FitzSimmons, R. (2014). On the importance of collaborative peer learning as a collective learning experience in Finnish higher education classrooms. Critical Education, 5(16), 1-17.

Fontana, A., \& Frey, J. H. (2005). The interview: From neutral stance to political involvement. In N. K. Denzin \& Y. S. Lincoln (Eds.), The handbook of qualitative research (pp. 695-728). London: Sage.

Frayer, D. A. (1999). Creating a campus culture to support a teaching and learning revolution. Cause Effect, 22(2), 10-17.

Galbraith, C. S., \& Merrill, G. B. (2015). Academic performance and burnout: An efficient frontier analysis of resource use efficiency among employed university students. Journal of Further and Higher Education, 39(2), 255-277. doi:10.1080(03 09877X.2013.858673

Gibbs, G., \& Coffey, M. (2004). The impact of training of university teachers on their teaching skills, their approach to teaching and the approach to learning of their students. Active Learning in Higher Education, 5(1), 87-100.

Gillani, N., \& Eynon, R. (2014). Communication patterns in massively open online courses. The Internet and Higher Education, 23, 18-26. doi:10.1016/j. iheduc.2014.05.004

Glocker, D. (2011). The effect of student aid on the duration of study. Economics of Education Review, 30(1), 177-190. doi:10.1016/j.econedurev.2010.08.005

González, M. D. L. O., Jareño, F., \& López, R. (2015). Impact of students’ behavior on continuous assessment in Higher Education. Innovation: The European Journal of Social Science Research, 28(4), 498-507. 


\section{Introduction}

Gormally, C., Evans, M., \& Brickman, P. (2014). Feedback about teaching in higher ed: Neglected opportunities to promote change. CBE-Life Sciences Education, 13(2), 187-199.

Graesser, A. C., Chipman, P., Haynes, B. C., \& Olney, A. (2005). AutoTutor: An intelligent tutoring system with mixed-initiative dialogue. IEEE Transactions on Education, 48(4), 612-618.

Gregory, M. S. J., \& Lodge, J. M. (2015). Academic workload: The silent barrier to the implementation of technology-enhanced learning strategies in higher education. Distance Education, 36(2), 210-230. doi:10.1080/01587919.2015.10550 56

Groen, J. A., Jakubson, G. H., Ehrenberg, R. G., Condie, S., \& Liu, A. Y. (2008). Program design and student outcomes in graduate education. Economics of Education Review, 27(2), 111-124. doi:10.1016/j.econedurev.2006.09.010

Hamer, J., Purchase, H., Luxton-Reilly, A., \& Denny, P. (2015). A comparison of peer and tutor feedback. Assessment \& Evaluation in Higher Education, 40(1), 151-164. doi:10.1080/02602938.2014.893418

Hannan, A. (2005). Innovating in higher education: Contexts for change in learning technology. British Journal of Educational Technology, 36(6), 975-985. doi:10.1111/j.1467-8535.2005.00568.x

Hansen, B., \& Lang, M. (2011). Back to school blues: Seasonality of youth suicide and the academic calendar. Economics of Education Review, 30(5), 850-861. doi:10.1016/j.econedurev.2011.04.012

Hartog, J. (2000). Over-education and earnings: Where are we, where should we go? Economics of Education Review, 19(2), 131-147. doi:10.1016/ S0272-7757(99)00050-3

Hébert, T. P. (1993). Reflections at graduation: The long-term impact of elementary school experiences in creative productivity. Roeper Review, 16(1), 22-28.

Helmke, A., \& Schrader, F. W. (1988). Successful student practice during seatwork: Efficient management and active supervision not enough. The Journal of Educational Research, 82(2), 70-76.

Howell,A.J.(2009).Flourishing:Achievement-related correlatesofstudents'well-being. The Journal of Positive Psychology, 4(1), 1-13. doi:10.1080/17439760802043459

Howland, J., \& Wedman, J. (2004). A process model for faculty development: Individualizing technology learning. Journal of Technology and Teacher Education, $12(2), 239$.

Jakku-Sihvonen, R., \& Niemi, H. (Eds.). (2006). Research-based teacher education in Finland - reflections by Finnish teacher educators. Helsinki: Finnish Educational Research Association.

Keup, J., \& Barefoot, B. (2005). Learning how to be a successful student: Exploring the impact of first-year seminars on student outcomes. Journal of the First-Year Experience \& Students in Transition, 17(1), 11-47.

Kokkelenberg, E. C., Dillon, M., \& Christy, S. M. (2008). The effects of class size on student grades at a public university. Economics of Education Review, 27(2), 221-233. doi:10.1016/j.econedurev.2006.09.011

Kolbe, R. H., \& Burnett, M. S. (1991). Content-analysis research: an examination of applications with directives for improving research reliability and objectivity. Journal of Consumer Research, 18(2), 243-250.

Langford, R., Bonell, C. P., Jones, H. E., Pouliou, T., Murphy, S. M., Waters, E., Komro, K. A., Gibbs, L. F., Magnus, D., \& Campbell, R. (2014). The WHO health 
promoting school framework for improving the health and well-being of students and their academic achievement. Wiley \& Sons. Retrieved from http://s3.amazonaws. com/academia.edu.documents/43141772/The_WHO_Health_Promoting_ School_framewor20160227-10383-138103u.pdf?AWSAccessKeyId=AKIAJ56TQ JRTWSMTNPEA\&Expires=1477067896\&Signature=CA4GSGCKdnp97FSOgA N09dqavzE\%3D\&response-content-disposition=inline \%3B\%20filename\%3DThe WHO_Health_Promoting_School_framewor.pdf

Lavonen, J., \& Laaksonen, S. (2009). Context of teaching and learning school science in Finland: Reflections on PISA 2006 results. Journal of Research in Science Teaching, 46, 922-944. doi:10.1002/tea.20339

Lee, J., \& Cho, J. (2014). Who teaches economics courses better? Using student professor matched data for the principle of economics course. Applied Economics Letters, 21(13), 934-937.

Ludemann, P. M., \& McMakin, D. (2014). Perceived helpfulness of peer editing activities: First-year students' views and writing performance outcomes. Psychology Learning \& Teaching, 13(2), 129-136. doi:10.2304/plat.2014.13.2.129

Määttä, K. (2012). The pedagogy of supervising doctoral thesis. In K. Määttä (Ed.), Obsessed with the doctoral theses: Supervision and support during the dissertation process (pp. 143-160). Rotterdam: Sense Publishers.

Määttä, K. (2015). A good supervisor - ten facts of caring supervision. International Education Studies, 8(9), 185-193.

Määttä, K., \& Uusiautti, S. (2012). The four-leaf clover of human resources. Research Journal in Organizational Psychology and Educational Studies, 1(1), 37-42.

Määttä, K., Uusiautti, S., \& Määttä, M. (2016). A story of an ideal study process. In S. Uusiautti \& K. Määttä (Eds.), The basics of caring research (pp. 91-102). Rotterdam: Sense Publishers.

Mayring, P. (2000). Qualitative content analysis. Forum: Qualitative Social Research, l(2). Retrieved from www.qualitative-research.net/index.php/fqs/article/ view $/ 1089 / 2385$

Nutting, A. W. (2014). Tuition and the outcomes of community college attendance: Simulations for academic-program and occupational-program students. Education Economics, 22(6), 614-634.

OECD. (2016). Education at a glance. Paris: OECD Publishing. doi:10.1787/ eag-2016-en

Olwage, D., \& Mostert, K. (2014). Predictors of student burnout and engagement among university students. Journal of Psychology in Africa, 24(4), 342-350. doi:10 $.1080 / 14330237.2014 .978087$

Pajares, F. (2001). Toward a positive psychology of academic motivation. Journal of Educational Research, 95(1), 27-35.

Parker, J. (2008). Comparing research and teaching in university promotion criteria. Higher Education Quarterly, 62(3), 237-251.

Pennington, H. (2004). Fast track to college: Increasing postsecondary success for all students. Double the numbers: A jobs for the future initiative. Jobs for the Future. Retrieved from http://files.eric.ed.gov/fulltext/ED486158.pdf

Ramos, F., Pinto, M., Coelho, D., Raposo, R., Pombo, L., Pedro, L., Almeida, P., Batista, J., Morais, N., Souza, F., Balula, A., Lucas, M., \& Moreira, A. (2015). Tracing the use of communication technologies in higher education. In F. M. Ribeiro, Y. Politis, \& B. Culum (Eds.), New voices in higher education research and scholarship (pp. 157-174). doi:10.4018/978-1-4666-7244-4.ch008 
Rauscher, E., \& Elliott III, W. (2014). The effect of wealth inequality on higher education outcomes: A critical review. Sociology Mind, 4(4), 282.

Reed, R. J., \& Hurd, B. (2014). A value beyond money? Assessing the impact of equity scholarships: From access to success. Studies in Higher Education, 41(7), 1236-1250. doi:10.1080/03075079.2014.968541

Reiss, S. (2012). Intrinsic and extrinsic motivation. Teaching of Psychology, 39(2), 152-156. doi:10.1177/0098628312437704.

Rinne, R., Kivirauma, J., \& Simola, H. (2002). Shoots of revisionist: Education policy or just slow readjustment? The Finnish case of educational reconstruction. Journal of Education Policy, 17(6), 643-658. doi:10.1080/0268093022000032292

Salmela, M., \& Uusiautti, S. (2015). A positive psychological viewpoint for success at school - 10 characteristic strengths of the Finnish high-achieving students. High Ability Studies, 26(1), 117-137. doi:10.1080/13598139.2015.1019607

Sánchez-Sánchez, N., \& McGuinness, S. (2015). Decomposing the impacts of overeducation and overskilling on earnings and job satisfaction: An analysis using REFLEX data. Education Economics, 23(4), 419-432.

Schellenberg, B. J., \& Bailis, D. S. (2015). Predicting longitudinal trajectories of academic passion in first-year university students. Learning and Individual Differences, 40, 149-155. doi:10.1016/j.lindif.2015.04.008

Seligman, M. E. P., Ernst, R. M., Gillham, J., Reivich, K., \& Linkins, M. (2009). Positive education: Positive psychology and classroom interventions. Oxford Review of Education, 35, 293-311.

Shahidi, M., \& Sobhani, A. (2015). Psycho-educational problems in large academic classes: Learning motivation within psycho-educational atmosphere. Academic Research International, 6(1), 322, 324-333.

Shenton, A. K. (2004). Strategies for ensuring trustworthiness in qualitative research projects. Education for Information, 22(2), 63-75.

Stellmack, M. A., Keenan, N. K., Sandidge, R. R., Sippl, A. L., \& Konheim-Kalkstein, Y. L. (2012). Review, revise, and resubmit the effects of self-critique, peer review, and instructor feedback on student writing. Teaching of Psychology, 39(4), 235-244. doi:10.1177/0098628312456589

Stratton, L. S., O’Toole, D. M., \& Wetzel, J. N. (2008). A multinomial logit model of college stopout and dropout behavior. Economics of Education Review, 27(3), 319-331. doi:10.1016/j.econedurev.2007.04.003

Symonds, M. R. (2014). Lecturing and other face-to-face teaching - too much or too little? An assessment based on student feedback and fail rates. Higher Education Research \& Development, 33(6), 1221-1231.

Tagg, J. (2012). Why does the faculty resist change? Change: The Magazine of Higher Learning, 44(1), 6-15.

Tarvid, A. (2013). Unobserved heterogeneity in overeducation models: Is personality more important than ability? Procedia Economics and Finance, 5, 722-731.

Theilheimer, R. (1991). Involving students in their own learning. Clearing House, $65(2), 123-126$.

Topping, K. (1998). Peer assessment between students in colleges and universities. Review ofEducationalResearch, 68(3),249-276.doi:10.1177/1469787414527391

Työ- ja elinkeinoministeriö [Ministry of Economic Affairs and Employment]. (2016). Korkeasti koulutettujen työmarkkinapolut - työllisyys, työttömyys ja syrjäytymisriski [Employment paths of the higher educated - employment, unemployment, and the risk of exclusion]. Helsinki: Työ-ja elinkeinoministeriö. 
Uusiautti, S., \& Määttä, K. (2013a). How to train good teachers in Finnish universities. Student teachers' study process and teacher educators' role in it. European Journal of Educational Research, 1(4), 339-352.

Uusiautti, S., \& Määttä, K. (2013b). Enhancing student' study success through caring leadership. European Scientific Journal, 2(2), 398-407.

Uusiautti, S., \& Määttä, K. (2013c). Good teachers and good teacher educators: A glance at the current teacher education in Finland. Asian Journal of Education and e-Learning, $1(1), 1-6$.

Uusiautti, S., \& Määttä, K. (Eds.). (2015a). Critical eye on education. Tallinn: United Press Global.

Uusiautti, S., \& Määttä, K. (2015b). The psychology of becoming a successful worker: Research on the changing nature of achievement at work. Oxford: Routledge.

Uusiautti, S., \& Määttä, K. (2016). Caring research and its future challenges. In S. Uusiautti \& K. Määttä (Eds.), The basics of caring research (pp. 137-144). Rotterdam: Sense Publishers.

Välijärvi, J. (2014). Osaaminen kestävällä perustalla. Suomen PISA-tulosten kehitys vuosina 2000-2009. Tilannekatsaus helmikuu 2014 [Expertise on a secure basis. The development of Finland's PISA results in 2000-2009. A snapshot on February 2014]. Helsinki: National Board of Education.

Välijärvi, J., Kupari, P., Linnakylä, P., Reinikainen, P., Sulkunen, S., Törnroos, J., \& Arffman, I. (2007). The Finnish success in PISA - and some reasons behind it 2. PISA 2003. Jyväskylä: Institute for Educational Research.

Ward, D., \& Vargas, J. (2011). Incentives for early graduation: How can state policies encourage students to complete high school in less than four years? Policy Brief. Jobs for the Future. Retrieved from http://files.eric.ed.gov/fulltext/ED523105.pdf

Wierstra, R. F., Kanselaar, G., Van Der Linden, J. L., \& Lodeewijks, H. G. (1999). Learning environment perceptions of European university students. Learning Environments Research, 2(1), 79-98.

Woodward-Kron, R. (2002). Critical analysis versus description? Examining the relationship in successful student writing. Journal of English for Academic Purposes, l(2), 121-143.

Wray, N., Markovic, M., \& Manderson, L. (2007). 'Researcher saturation': The impact of data triangulation and intensive-research practices on the researcher and qualitative research process. Qualitative Health Research, 17(10), 1392-1402. doi:10.1177/1049732307308308

Xuereb, S. (2015). Academic resourcefulness, coping strategies and doubting in university undergraduates. Journal of Further and Higher Education, 39(2), 205-222. doi:10.1080/0309877X.2013.817004 

Taylor \& Francis http://taylorandfrancis.com 


\section{Part 2}

\section{Successful university students}

\subsection{The ideal study process and factors hindering it}

\section{The prevequisites of smooth study processes in universities}

Smooth progress in university studies is the hope and goal not only of every student but also of universities. Prolonged study processes do not serve anyone: they decrease students' motivation to perform and complete studies and discourage university teachers. A decrease in the number of graduating students means decrease in universities' funding, too; therefore, it is crucial to pay attention to the smoothness of studies from a student's point of view. We wanted to hear from university students themselves what the most important factors hindering them progressing in their studies are; we introduce our findings in this chapter.

A glimpse at previous studies and theories shows that success in studies is a sum of many factors. We have previously presented four core factors that direct students' study process: the student, university community, study plan, and university teacher (Määttä \& Uusiautti, 2012; see Figure 2.1). Although they may not explain successful study paths and learning comprehensively, they function as the basis of theoretical outline of this study.

Perhaps the most important factor in the study process is the student heror himself. Students' study skills, self-regulation, and attitudes determine their studying styles and skills and thus their opportunities of succeeding (Dresel et al., 2015; Phan, 2008). Likewise, students are heterogeneous, and their unique personalities have their own influence on their studies (Duff, Boyle, Dunleavy, \& Ferguson, 2004). Success in previous education levels (Busato, Prins, Elshout, \& Hamaker, 2000) directs performance in university studies. These experiences in students' learning and study history can either strengthen or sap their self-efficacy beliefs or self-confidence as learners (Furnham, Chamorro-Premuzic, \& McDougall, 2002). Therefore, for example, university entrance tests do not predict well students' study success at universities (Beenstock \& Feldman, 2016). Previous experiences have created for students a conception of themselves as learners, which can become questioned at the university level (Cano, 2005; Nicol \& Macfarlane-Dick, 2006). In addition, students' expectations and understanding about the length and demands of studies can be unrealistic (Brunello \& WinterEbmer, 2003). 


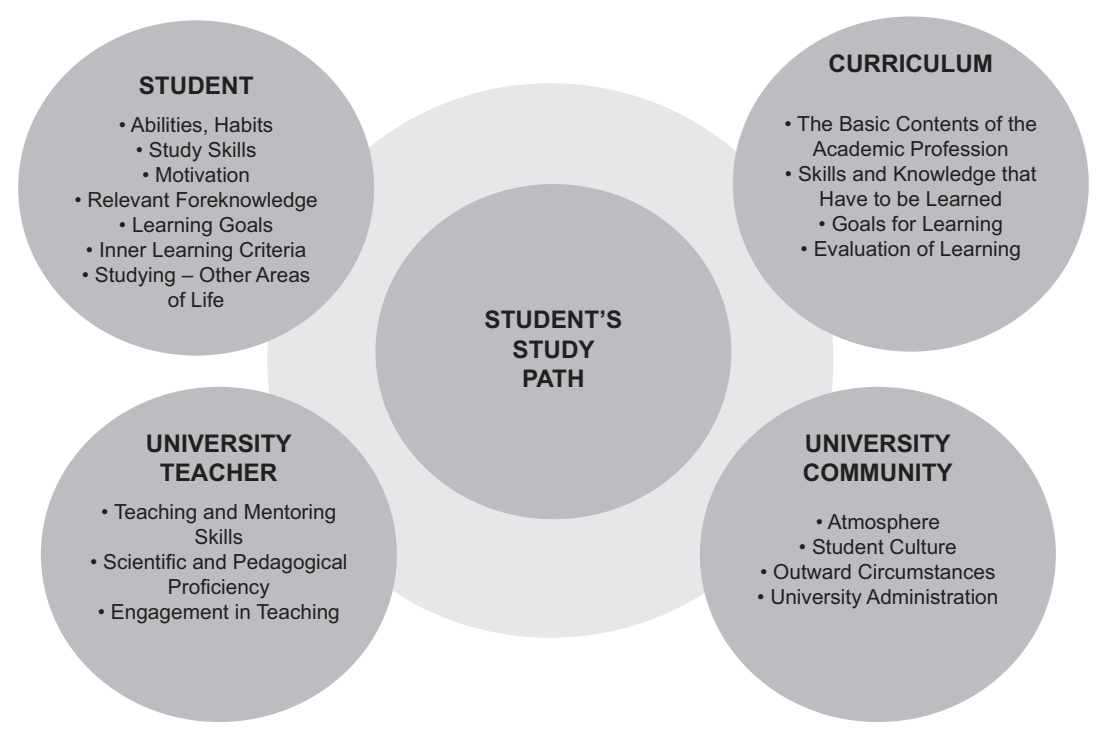

Figure 2.1 The ideal study process and factors hindering it (adapted from Määttä \& Uusiautti, 2012, p. 52)

Motivation to perform well and complete courses is another important ingredient of study success. Students' motivation is reflected in their way of performing studies and their persistence (Mills \& Blankstein, 2000; Pintrich, 1999; Salmela \& Uusiautti, 2015). Strong intrinsic motivation makes coping with study-related challenges easier because then learning and acquiring knowledge and skills are considered rewarding as such (see also Ryan \& Deci, 2000; Salmela \& Määttä, 2015). However, outer rewards can boost motivation, too: positive and encouraging feedback is important because it improves students' receptiveness to new learning experiences and tolerance of failure (Aoun, Vatanasakdakul, \& Ang, 2016). It is important to remember that students do not just live for their studies; rather, their lives are filled with other important areas, too, that are equally important for their comprehensive positive development (see e.g., Lerner, Lerner, von Eye, Bowers, \& Lewin-Bizan, 2011). Indeed, studies should also be in balance with other areas of life; interesting hobbies, good human relationships and family life, versatile and relaxing leisure time act as a good counterbalance to studying (e.g., Lowe \& Gayle, 2007).

Students' personal features are not, however, the only factor influencing their success; they are always a part of the university community that surrounds them and that either enhances or hinders their chances of succeeding. Many characteristics of university community influence students' study processes (Chamorro-Premuzic \& Furnham, 2003; Conard, 2006), and one of the closest features to students is teaching. Numerous studies have outlined the features of 
teaching that enhance the study processes the best (DePillis \& Johnson, 2015; Uusiautti \& Määttä, 2013; Äärelä, Määttä, \& Uusiautti, 2016). Teaching skills and teachers' ability to have appreciating interactions with students and to guide students are still the bedrock of university education. Teaching skills can be practiced and developed. Yet the completion of an academic degree is each student's responsibility because even the most skillful teachers cannot learn on students’ behalf (Määttä \& Uusiautti, 2012; Äärelä, Määttä, \& Uusiautti, 2016).

When it comes to curriculum planning and teaching arrangements, faculties and departments vary from authoritative to democratic. The curriculum provides both teachers and students with clear goals, and current renewals of university curricula aim at enhancing work-life knowledge and skills across studies (Chappel \& Johnston, 2003; Fallows \& Steven, 2000; Xu, 2004). Curriculum planning can also pay attention to the study progresses and their phases and therefore turn curricula into more student centred in nature (Valle et al., 2003).

Students are expected to perform more and better (Stellmack, Keenan, Sandidge, Sippl, \& Konheim-Kalkstein, 2012). Within the pressure of increasing extrinsic demands and personal goals, students' motivation becomes tested (Reiss, 2012). At its worst, bewilderment can result in dropping out of education (Cortes, Mostert, \& Els, 2014; Stratton, O’Toole, \& Wetzel, 2008) or in fatigue (Galbraith \& Merrill, 2015; Olwage \& Mostert, 2014).

\section{What hinders success according to the university students' perceptions?}

We wanted to know what factors make studying and study progress difficult and asked first-year students at the University of Lapland about this. This selection was based on the findings according to which the first study year is the most important for the smoothness of forthcoming study years as well (e.g., McKenzie \& Schweitzer, 2001; Rodger \& Tremblay, 2003). We wanted to find out (1) what the most difficult issues the students have faced during their first year of university studies have been and (2) what factors have hindered their study progress according to their own perceptions.

Deficiencies in study skills required in university studies formed the main category in the students' answers. This was the main hindrance of smooth study progress during the first year of university studies. Most of the students did not have previous experience of university studies, and even if the university arranged orientation lectures to discuss relevant study skills, adjustment to the new study environment did not happen immediately or even easily. In general, study methods needed at the university level were reported unfamiliar; therefore, the beginning of the study process was slow and tangled for many first-year-students:

At the beginning, it was difficult to get in to the various learning environments.

To learn new study methods; lectures, making notes from speech and not directly from transparencies, preparing to exams with huge pile of literature. 


\section{Successful university students}

Sometimes new students may find it difficult to find and learn new study techniques that suit them the best. They would like to know exactly how to prepare for exams or how to write answers to essay questions and what an essay or learning diary is.

To find a reading style that fits. I have not been able make good plans of how to read to exams. Neither have I found a suitable study method and therefore my success in exams has been quite lame, and I bave not obtained too much study points.

Adjustment to academic studies is difficult at the beginning. The general university practices are not familiar, and adjustment to the academic atmosphere takes time. Studies at a university require more self-control, independence, and initiative than previous studies in upper secondary education. Numerous students mentioned how hard it was to impel themselves to study and find a study rhythm. The ability to carry on studies after failing in exams was also mentioned as a very demanding situation that decreased motivation and required extra effort.

At first, finding a study rhythm (different/more relaxed/more responsibility than in the general upper secondary education).

Familiarization with more freely and voluntary studying was simultaneously liberating and, at times, problematic.

Too often have I started to read to an exam a couple of nights before it but toward the end of the study year, I have tried to mend my ways.

Finding a reading rhythm in independent studies; maintaining self-confidence, and spurring myself after getting an F and restarting studying.

Unclear directions in studies had caused problems as well. Students reported that they had found guidelines for exams unclear, insufficient, and confusing. Likewise, guidelines of how to write essays and use learning diaries were considered ambiguous and difficult to understand. Students complained that teachers' requirements for parts of a course had been diverging and that they are not always aware of what kind of performances teachers actually expect.

Unclear directions regarding exams. In my first exam, I wrote too long answers and lost points. In the next one, I wrote more shortly, and then required information was missing. Each exam should have their own separate directions of how to perform in that exact exam.

Study plans and scheduling were mentioned as one of the core issues hindering smooth studies. Independence in studies necessitates skills to plan one's study schedules. Students considered it difficult to perceive their study paths and the workload in their plans. Students had encountered trouble sticking to their study schedules or sparing enough time for studies and preparation for exams.

The most difficult thing has been to realize how much work each task requires (essays, exams, seminars, etc.) because different teachers demand different kinds of imput. 
You have to plan everything by yourself and, every now and then, you relapse into too ambitious performing which tests your coping.

Adjustment to university studies, time management, and reasonable distribution of your resources.

Lack of guidance in studies was mentioned as a hindrance. Students reported that they had not received enough guidance in how to select courses and minors as well as in planning of their studies in general. They mentioned that they had not received sufficient information beforehand about courses available and what the course contents are and what they should select.

Starting your studies was the most difficult at first. I felt that I did not get enough guidance for planning my studies.

In the fall, I was not certain which courses I could already select [in my study plan].

There has not been much study counseling.

Lack of guidance and difficulties in finding help at the beginning of studies are major problems and can cause long-lasting trouble because some courses should be studied in a certain order. There are also courses that are offered only every second year. Therefore, it is important to provide students with these kinds of information clearly and promptly straight at the beginning of the first study year. On the other hand, these are also details that students easily forget in the middle of the start of their studies when they have numerous other issues to solve and think about, too. Therefore, guidance should be available through the school year so students can return to these questions when they need help with them the most.

Many students were also disappointed with tutoring. Both student and teacher tutoring were considered insufficient. Students considered group meetings important, and they wished that they would be regularly arranged and offer more help with study planning.

Lack of community or one's own group and loneliness were also commonly mentioned in the data. Many students arrive to the university from across the country; therefore, they have to start building new friendships and other relationships at the same time they start their new, demanding studies. Student tutoring, in which older students guide the newcomers, has proven a good way of getting new students to get familiarized with their new study place, the university and the city, and their new study groups. Still, experiences of the start varied among the participants and the loneliness of university studies had surprised many of them.

Studying is somewhat lonely business.

Adjustment to this new place, which I, however, knew already beforehand.

The most difficult thing for me has been to get to know my own group, the other first-year-students. I took so many different courses than the others, and therefore, I met hardly anyone after the orientation week in the fall. This is greatly my fault too. 


\section{Successful university students}

Finally, overlapping courses and busy study periods were reported to hinder smooth progress. Students found it difficult to determine when to take or attend courses if there were, for example, two courses going on at the same time with partly or mostly overlapping lecture times. Some courses did not allow absences, and thus, students had to make difficult selections, especially if the ways of performing courses could not be negotiated with teachers. Some periods had been extremely busy and toilsome because of numerous lectures, exams, and other tasks. Another big problem was difficulty in getting exam books from the library; students may have to wait for a long time for certain much-used books.

Teaching is accumulated. I have really full months with lectures and exams, and then months that I have not have suitable lectures available at all. Many study groups have too little space and I have not gotten in in them.

Students' descriptions of the factors that hinder their smooth study progress were varied. As the results show, these vary from study skills to more general problems, such as overall scheduling of courses. Most of these hindrances as unnecessary, which means that they can be addressed and that there already are suitable, wellknown ways of fixing these problems.

\section{University students' descriptions of study success}

In another study, we wanted to hear students' descriptions of their positive study experiences. This viewpoint provides a good counterbalance to the previous descriptions of hindrances of success. The main purpose was to discover the factors that make studying and study progress smooth and lead to successful outcomes according to students' perceptions. We asked the students (1) what the most pleasing study experiences they have encountered in university studies have been and (2) what factors have enhanced their study progress and success according to their own perceptions. We divided the success factors into eight categories.

The most important element of success was experiences of successes. They increased students' study satisfaction and contentment. Successes were reported to boost students' sense of efficacy and capability. Especially, passing a demanding exam after studying hard provided a benign positive experience. Many of the students mentioned that passing the very first exam at the university was a memorable event. Indeed, the meaning of a good start, whether it was in studies, at school in general, or in a new workplace, should never be underestimated (see e.g., Keup \& Barefoot, 2005; Schellenberg \& Bailis, 2015). The students described their positive experiences as follows:

\section{Passing the first exam}

Studying and reading numerous books require dedication and persistence, but when good grades are achieved, motivation increases, and studying provides joy. 
Good grades and surpassing one's own expectations were also mentioned as factors of boosting success. Smooth study progress was described as an especially pleasant study experience.

\section{To handle a difficult course well. \\ When the first exam went better than I expected.}

Successes are a mark of right kinds of study skills and ability to adjust in the academic study environment. Therefore, it is important to become familiar with one's strengths and weaknesses as a student as well as oneself as a learner (González, Jareño, \& López, 2015).

The students also acknowledged good relationships with other students as an important success factor. More often than not, students have to move to a new place to study, leaving home and old friends behind. Finding new friends among peer students helps their engagement with their studies and the study place and functions as a social resource during student life (see also Vaarala, Uusiautti, \& Määttä, 2013).

New friends are worth their weight in gold.

Working together makes studying meaningful (see also FitzSimmons, 2014). According to the data, the sense of belonging to a group and acceptance form a source of encouragement. Peer support and advice from older students were also perceived meaningful for successful study progress (see also Hamer, Purchase, Luxton-Reilly, \& Denny, 2015; Ludemann \& McMakin, 2014; Wierstra, Kanselaar, Van Der Linden, \& Lodeewijks, 1999; Topping, 1998).

The absolutely best positive experience during this study year has been the people of my own study group and the fact how well I get along with them all.

Creating the excellent group spirit in our home group; studying is nice in a good team.

Students also described the wider study environment and emphasized the importance of an open atmosphere at the university. According to their experiences, the smallness of their university made it easy to approach teachers and professors, and most of them found interaction with them immediate and relaxed. A positive and encouraging atmosphere was therefore named as one element in successful study processes. They had noted that not only positive relationships between students but also teaching personnel were valuable.

The small size of the university increases communality.

The overall atmosphere is nice and relaxed between students and teachers. It is nice that you can ask teachers help. 
Indeed, the students seemed to connect the positive atmosphere (see also Shahidi \& Sobhani, 2015) with the opportunity of asking for help and being helped when needed. It has been noted that prompt, timely help and support (instead of keeping students dwelling with their concerns) are important conditions of timely graduation (Cortes, Mostert, \& Els, 2014). If students believe that their worries are nullified, that they do not dare to bother the teaching personnel with their questions, or that they are ignored, even the smallest issues that could be solved easily can accumulate into big problems and lead to prolonged studies and even dropping out (Cortes, Mostert, \& Els, 2014; Määttä, 2016; Olwage \& Mostert, 2014; Stratton, O’Toole, \& Wetzel, 2008).

Teaching and teachers' dedication and enthusiasm were perceived as inspiring and motivating. The students appreciated teachers who invested in their teaching methods and styles and the contents of their lectures. Teachers and courses that were the most pleasing to them were mentioned by name in the data.

To get the exact information from the course that you were looking for. Interesting teachers who put their soul into teaching make lectures interesting even if the theme wasn't.

Also, the group communication course was interesting and especially nice, and the teacher was competent.

Interesting themes

Face-to-face teaching was appreciated in the data, but students also noticed teachers who used varied teaching methods. They had enjoyed the variety and had also perceived that more often than not, different methods provided an opportunity to study faster.

The teaching personnel consists of very nice and warm people. I have been able to study online which has suited me well.

Students in the data emphasized that studies and studying itself were rewarding. Learning about one's field and research, and recognizing development in themselves had been exciting and even surprising. The aforementioned variety in study methods especially showed their strengths and resources and strengthened their belief in their abilities. When studying itself becomes a motivating factor, instead of just achievements and measurable goals, we can talk about intrinsic motivation.

Studying itself has been rewarding, after my years at work.

Learning new things.

It has been great to notice new sides in myself. For example, I didn't consider myself very profound or apt to academic thinking previously but courses that have gone well and positive feedback have improved my self-esteem and I feel like the university is the right place to me. 
Studying just for yourself has been lovely. I feel like having come to a place where I can study in way that is meaningful to me. My experience is that I have been able to express myself and that I have been appreciated.

Activities in studies and practical training or practicums as well as connections to work life were highlighted in the data as good experiences. Various small group tasks and seminars were reported as pleasing study methods. Practical training related to one's field increased motivation and enthusiasm.

The first practicum and group lessons.

All those courses that have allowed me to do things in practice, e.g., graphical technology and software courses. Learning has been concrete during those courses and I have noticed my development clearly.

One singular experience is 'Leadership and organization' course which had those strategic development workgroups that were challenging but rewarding and inspiring to perform. Studying felt relevant and comparable to methods used in actual work. Thinking about skills needed at work, the course was apparently beneficial, to develop those skills.

Practically-oriented courses, such as 'Conciliation' and 'The witness's support'. They gave me more than ordinary literature exams.

As their studies went on, many students had become convinced that their own field of studies or their major had increased their satisfaction in their studies. Their choice had proved to be right when they had noticed that their field had started to interest them increasingly. It met their expectations, and they felt that they wanted to develop as experts in their own field. This is also about finding a field that corresponds with one's strengths. Being able to use one's signature strengths and developing in their direction can become the most valuable source of well-being in life (Van Niekerk, Mostert, \& de Beer, 2016) - making studies also seem especially meaningful.

Studies in my own field have been the most rewarding.

The most pleasing thing has been when I realized that this is it, this is what I want to do.

When talking about study satisfaction and success, many students mentioned that they wanted to schedule their studies in a way that suits them best. Indeed, flexibility in teaching arrangements and study schedules were frequently mentioned factors of success. Various optional ways of performing studies - for example, writing essays instead of literature exam - were mentioned as factors that speed up studies. Variety and optional tasks were considered beneficial. Different teaching arrangements, such as online lectures and self-scheduled exams in the so-called computer-based exam class, brought much appreciated flexibility in studies.

Good opportunities to perform studies by writing essays. 
Self-scheduled exams, online exams, and online courses make planning your own schedule effortless.

Flexible timetables and opportunities to online participation in lectures make studying easier. Freedom, autonomy, and self-directed studies were reported as positive experiences and as dimensions that they had not learned until entering the university. Flexibility was also appreciated by students who worked alongside studies as well as by those who had children and had to arrange child care during their studies.

The best thing has been to notice how flexible studying is. The courses has lasted three weeks at the most, while most of them have been one-or two-week-long spurts. Due to flexible schedules, I have been able to spend a lot of time in my home city and work alongside studies.

The most pleasant study experiences have been related to participatory teaching methods and flexible practices.

The last main category found in the data covered the active and positive feedback given by teachers. Personal comments and individual feedback were regarded as support and encouragement. Students reported that the constructive feedback about their performances in essays, exams, or other tasks helped them find the right direction in their studies. They also received information about their development, strengths, and ways to perform various tasks.

I have received personal comments and feedback about my work.

The sense of development and feedback from teachers.

Some courses have been especially high-quality, and I have learned good practical skills that have developed my expression. . . In these courses, teachers have been ready to give advice and guide, due to which these courses have given me so much.

The teacher who evaluated provided plenty of constructive feedback, and inspired and encouraged me...

\section{From students to teachers}

One of the ways to improve students' study progress can happen through the university teachers and professors. They are responsible for the development of their own disciplines and fields of research, and this cannot happen without proper guidance and education of new generations of students. The quality of university teaching can be evaluated with many criteria: substance knowledge, breadth, topicality, theory versus practice orientation, necessity versus redundancy, interesting versus platitude, difficulty versus intelligibility, fragmentariness or structure, hastiness or concentration. Ideal university teaching is based on research (Määttä \& Uusiautti, 2012) and shows students how university research interacts not only in the field but with the teaching at universities as well. Shulman (1987) 
argues that content knowledge should merge with pedagogical knowledge in university teaching.

Still, just good teaching is not enough (Helmke \& Schrader, 1988), and it might be even more important to know how students perceive their education and how capable they are to plan their studies and achieve their goals. Indeed, students' worries are not just related to teaching. For example, one reason for prolonged studies is that students want to study extensively, and this may guarantee their employment (Dolton \& Silles, 2008; Hartog, 2000). This kind of overeducation can also hinder the smoothness of studies in many levels, such as studies that are too burdensome, consecutive fatigue, and imbalance between studies and other areas of life (Budría \& Moro-Egido, 2014; Sánchez-Sánchez \& McGuinness, 2015; Tarvid, 2013). However, for some students, other areas of life may leave studies in the shadow (Chesser, 2015). Finally, sometimes studies become hindered by financial problems (Dockery, Seymour, \& Koshy, 2016; Reed \& Hurd, 2014).

The findings we have introduced here are supported by several earlier studies on the importance of positive feedback, constructive evaluation, and mentoring or tutoring. At their best, they improve students' initiation and activity in their studies as well as their ability for self-reflection and to evaluate their own learning and study skills (Boud \& Molloy, 2013; Carless, Salter, Yang, \& Lam, 2011; Ćukušić, Garača, \& Jadrić, 2014). Students need ongoing feedback to develop as students, learners, and members of an academic community (Winstone, Nash, Rowntree, \& Menezes, 2016; Winstone, Nash, Rowntree, \& Parker, 2016), which sets demands on university education. New methods of student counseling and guidance (see e.g., West \& Turner, 2016) can provide some means to address these needs, but they necessitate plenty from teachers, too.

\subsection{PhD studies as described by doctoral students themselves}

\section{The special nature of the PhD dissertation process}

The dissertation process is an unforgettable and special phase of life for everyone seizing it. A PhD degree is greatly respected even though the number of graduating doctors has quadrupled during the past 20 years (see e.g., Chambaz, Biaudet, \& Collonge, 2006). Still, the work and effort the process requires have not diminished, and we can talk about an ultimate performance when we talk about doctoral theses.

Writing a doctoral thesis requires an enormous effort and perseverance as well as talent and ambition (Dill et al., 2006; Green \& Powell, 2005). A doctoral thesis has to meet official academic standards. However, these standards do not describe how a doctoral student's personal everyday life will change for the years of the dissertation process and how it demands adjustment, effort, and support and empathy from the PhD student's family and friends.

Actually, the emphasis on top performance starts at school. Students' progress and learning are controlled continuously through exams and tests, both locally 
(e.g., Konttinen, 1995; Lundgren, 2002; Simola, 2002) and internationally (Baker et al., 2010; Corcoran, 2010; Rothstein, 2009; Wiliam, 2010). The current trend seems to be that students are encouraged and even expected to surpass their limits and reach optimal performances, and this is expected to continue when they enter the world of work as well (see e.g., Uusiautti \& Määttä, 2015). Is it realistic to expect this? And what is the connection between top performing and flourishing?

The viewpoint provided here is based on our numerous studies on the psychology of human strengths and positive development (e.g., Määttä, 2011; Määttä \& Uusiautti, 2012; Salmela \& Uusiautti, 2013; Uusiautti, 2013; Uusiautti \& Määttä, 2013; Uusiautti \& Määttä, 2015). It complements the analysis of university students' success in studies by viewing the completion of a doctoral degree as a manifestation of a top performance.

The core concepts here are the motivational base of performance, human resources, and positive experiences leading to top performance (e.g., flow). The purpose is to discuss the importance of multiple elements of performing and the positive support and encouragement that foster the discovery of states of optimal and positive experiences at doing at one's limits in the university world. This chapter introduces PhD students' experiences, but in Part 3, we will also pay a special attention to supervisors' opportunities to enhance their doctoral students' success.

\section{The concept of performance}

The completion of a doctoral thesis is always a performance and is actually quite a unique one. However, the concept of performance is not simple and must be defined carefully. Frequently, performance is confused with its neighboring concepts, such as competence, behavior, or action. It is crucial to realize the differences among them. Behavior, for instance, is a combination of various motivational elements, such as focus, attention, interest, and persistency, and can be influenced by competence, among others. Performance is the result of behavior; it is something measurable and comparable and a clearly definable result (Thompson, Stuart, \& Linsay, 1997).

Thus, an actual performance is a combination of various elements - both individual- and context-specific ones. First, the processes have a holistic nature, which means that success is merely a result of the functional interaction of its elements rather than how each element influences entity (Tsang, Jardine, \& Kolodny, 1999). Second, the inner processes, such as mental, biological, and behavioral functions, and outer processes, such as opportunities, obligations, and rules, and how well these processes are synchronized contribute to the possibility of a top performance (Mitchell, 1997). Mitchell's (1997) model of performance highlights this connection between the context and individual features and motivation. People respond to the situation with their skills, knowledge, goals, values, and mood, but the context includes the task, colleagues or other people connected to the situation, work environment, and culture. In addition to each 
other, these categories can influence motivation. Motivation together with abilities, work knowledge, and context-bound factors leads to behavior, which again leads to performance.

Mitchell (1997) emphasizes that all theories that attempt to describe performance, whether they are belief, goal, efficiency, or expectation value theories, share certain features. Goals describe what we want to do, self-efficacy describes what we think we can do, and expectations describe our best evaluation of the consequences our action can have. All these, directly or indirectly, influence motivation and are also connected to effort, attention, persistence, and strategies. This idea is based on the finding that positive experiences concerning one's own doing make for one of the most central dimensions of good performance (Uusiautti \& Määttä, 2011; see also Liden, Wayne, \& Sparrowe, 2000).

It is important to analyze some of the core concepts that might help with an understanding of the positive experience of doing. Competence is often confused with performance, but they are not synonymous (Kanfer \& Ackerman, 2005). Competence refers to a more stable state or to a person's characteristic (Rychen \& Salganik, 2003). Performance is a momentary happening and can vary according to many factors, even if competence is high in relation to the task at hand.

Lynch (2013) names five basic dimensions and two meta-criteria for a performance. He also considers them as manifestations of quality in performance. Kanfer and Ackerman (2005) distinguish two dimensions of performance: maximal and typical performance. The former refers to a person's skills and abilities and describes all that the person can do when inner states (e.g., sleep, concentration) are optimal and when it is possible to concentrate on the task. The latter dimension is typical behavior, which refers to how the person usually does things or how he or she is likely to perform. The researchers point out that although maximal performance is an interesting research target, it would perhaps be more beneficial to pay attention to the difference between what the person can do and what he or she actually does (see also Stoltenberg, 2005).

The concept of self-efficacy is also closely related to competence and performance. Self-efficacy is a person's assessment of his or her own abilities to use his or her resources and to regulate his or her behavior to perform a task (Caprara \& Cervone, 2006; Judge, Locke, \& Durham, 1997; Mitchell, 1997). It is therefore similar to the aforementioned sense of competence. It has been shown that positive self-efficacy improves a person's performance and well-being in numerous ways (Schunk \& Pajares, 2005). People who have high self-efficacy devote more to their activities and persevere more than those who estimate that their competence is weaker. In addition, people with high self-efficacy are likely to select more high-level goals and engage in them (Bandura, 1997; Mitchell, 1997).

We consider a dissertation process an example of a top performance and acting at one's limits. What kind of mastery of skills would can lead to optimal top performance? How important will the positive emotion as one of the keystones of learning be in a dissertation process (cf., Chafouleas \& Bray, 2004)? What are the most salient issues supervisors should consider when supervising PhD students' dissertation processes? 


\section{Successful university students}

We will first introduce PhD students' own descriptions of the various phases of a dissertation process in general to provide an outline of the process in Finnish universities. After that, we focus more closely on dissertation processes as top performance, which connects $\mathrm{PhD}$ studies closely to the concept of study success.

\section{PhD Students' descriptions of the phases of a PhD research}

\section{(1) Getting started}

How does one decide to study a doctor's degree? Certainly, the decision is not always a straightforward one and can be preceded by various phases of doubts that have to be conquered.

\section{Me writing a doctoral thesis? Never.}

The first thoughts of a student who contemplates doctoral research can be quite hesitant (see also Golde, 2000). At the beginning of the dissertation process, uncertainty, self-protection, and even mystical expectations occur.

As if I was asked to fly a UFO from point $A$ to point $B$.

Doubts about one's resources are daunting. Nor does anyone want to let him- or herself down or set too high goals for his or her capability (see Rae, 2002), as described one of our PhD students:

Why on earth should I be doing a doctoral thesis? I could study an interesting phenomenon for the fun of it'.

On the other hand, apparently many want to test their limits and abilities.

Starting to write a doctoral thesis may engage and attract for a long time. The pendulum between starting and withholding is present (see McWilliam, Lawson, Evans, \& Taylor, 2005). The workload as such is not frightening. Many are ready for hard work, but the uncertainty and doubts about one's own survival create ambivalence. Usually, $\mathrm{PhD}$ students do not have any previous experiences of writing a doctoral thesis, and therefore, the process is the first and only one for them.

Of course, some students have decided to start to do doctoral research even before their master's thesis has been completed (see e.g., Peura, 2008). The process seems well defined and goal oriented with work schedules and such. The decision to write a doctoral thesis and to overcome all the obstacles, whatever comes, proves to be worth its weight in gold, especially at the finish line of the dissertation process.

A salient reason for starting postgraduate studies is the attractiveness of a researcher's career. A master's degree provides one with scientific resources, and some students have a compulsion to continue doing research and to experience 
the relaxed joy of researching. The academic merits can be considered attractive, too.

Indeed, the motives to start PhD studies can be the most varied (see e.g., Doncaster \& Lester, 2002). Other people's success can be inspiring:

When I was in my colleague's public dissertation event, I became inspired to start writing a doctoral thesis. Previously, I had thought that it would be such a utopia that is far from real life.

Another motive is to do something valuable that has wider use. A doctoral thesis can aim at helping those who have experienced a bitter fate, opening others' eyes to see or giving hope. Some PhD students think that their duty is to provide more information about the theme they are interested in. Many doctoral candidates find their research theme from work. Thus, their work as such may provide a natural research context:

In my work, I had to constantly search for more information and knowledge as the field was undergoing a transformation, so why should I not start researching.

Inspiration can break out in the spur of the moment or during a continuous and constant thirst for learning and studying (see Johnson, 2001). Studying just feels nice.

I started to write my own doctoral thesis after dreaming of it for a long time. I have always enjoyed studying. Additionally, doing research suited my life situation well.

\section{(2) Being hooked on the dissertation process}

After getting started and into one's stride, many students become hooked on the dissertation process (Määttä, 2012; see also Doncaster \& Lester, 2002). The obsession of writing a doctoral thesis and working with it may feel hard, and one may even lose one's grip on reality momentarily. Writing a doctoral thesis may also represent a new phase of life (see also Leonard, 2001).

After being a housewife, doing research meant diving into my own world for me. I was able to search information and write about a subject that really interests me all by myself.

PhD students write emails in the small hours, noticing that 'the day has already changed', which tells about the inspiration and dedication doing a PhD research can ignite. The work pace may be hard labor or the strengthening and rewarding of mental energy and attention akin to flow (Csikszentmihalyi, 2000, 2008). The significance of this positive state is further discussed later in this chapter. 


\section{Successful university students}

When concentrating on a doctoral thesis, many fail to do housework and clean; they 'fail to dust and clean the closets'. A PhD student may feel entitled to take time to her- or himself and pass on everyday duties:

My family was amazed because the mom was just writing all the time. My children are quite old but used to having me available. Now I am not. I love being selfish.

One doctoral student got a book called The Cleaning Book from her colleagues at her postdoctoral party, in which there was immemorial and felicitous remarks on her: 'Mundus mutatur, pulvis remanet-The world is changing, dust remains'. The postdoctoral party reminded her of the return to everyday life and reality after the dissertation process.

A doctoral student creates a world of his or her own for him- or herself (Doncaster \& Lester, 2002; Maltfroy \& Yates, 2003), which includes autonomy of a special kind and enthusiasm for searching for information (Murray \& Lawrence, 2008) as well as a feeling of competence (Ryan \& Deci, 2000). Researching and studying form a central part of one's own life and world.

Taking care of one's own well-being may also be forgotten, or one tends not to have enough time for rest, exercise, or eating. Indeed, the writing may turn into 'a dangerous sport' that tests one's health. For some, the monotonous sitting at the computer causes tenosynovitis, a stress injury of a leg, or other physical injury, and others may worry about something worse:

My deterioration started now from my legs and the lumbar region is hopefully not proceeding very fast upwards.

Surely, there are also many who consider writing a doctoral thesis as ordinary drudgery, systematic working that proceeds step by step:

Writing a doctoral thesis requires rigorous work. The files and references have to grouped, noted, and kept in order. You just have to sit, read, and write persistently.

\section{(3) Social life in test}

During the finishing phase of a doctoral thesis, socializing skills are also frozen, and the ordinary exchange of thoughts necessarily is not at its best, either. A researcher who has become absorbed in the world of a doctoral thesis may seem absent and distant:

Being absent-minded and talking fuzzy, my husband often noted that apparently I have had a little too rough a day. 
Interaction and dealings with others is halting, and even one's own train of thought seems abnormal. A doctoral student may lose previous friendships when concentrating closely on his or her own research (see Bolker, 1998). Former friends seem different. One does not get any response, and previous topics do not interest anymore. Some convey their concern about their will to retire from the world as well as their inability to be interested on others' 'trivial' matters. However, many PhD students are aware of the temporary nature of the process:

Interaction with others seems quite a hassle. Next, I will try to behave calmly and in a civilized manner.

However, the feeling of alienation amazes PhD students themselves as well. To be able to be alone with doctoral research is like a double-edged sword (see e.g., Delamont, Atkinson, \& Parry, 2000; Leonard, 2001); it is enjoyable and liberating but also harrowing:

Working alone and the detachment are the hardest in writing a doctoral thesis.

On the other hand, the agony of laboring alone is being eased by the brand-new support contacts that come along during the dissertation process. The research work familiarizes the $\mathrm{PhD}$ student with new people, and long-term friendships may spring up between people who are experiencing the same. Participation in PhD seminars can turn into the greatest source of support and social contacts during the research process.

In addition to the peers in the $\mathrm{PhD}$ seminar, the companionship between a supervisor and $\mathrm{PhD}$ student is special and significant by nature. While the seminars can turn into a profound exchange of experiences, questions, and perspectives as well as appreciation (Eraut, 2004), the supervisor's task as 'a master of ceremonies' is to make this enriching interaction possible (see also Himanen, 2007).

\section{(4) Balancing between demands and expectations}

There is no deadline for finishing a doctoral thesis. A PhD student should not be stressed out because of hurry because there is no external need or date. Nevertheless, a doctoral student's own need for completion may become quite a whip. The question is all the more to prove to oneself, when one's own performance, powerful goal orientation, and inner motivation work as catalysts. The promises of a schedule for completion help a family and circle of acquaintances to understand and support the process, and determined working becomes easier:

It has been hard as a mother and when working with a demanding job to constrain oneself from overburdening. One has to draw up a realistic schedule and bold on to that. 
Usually, a schedule makes one committed, but if it is too hard, it can turn into a burden or stressful baggage. Sometimes it is necessary to keep one's own work at arm's length (see Cryer, 2003) or take a pause:

Now I have to admit that the whole subject seems repulsive. I have to take a break if that helps to continue.

Still, it may be difficult to detach oneself from the grasp of writing a doctoral thesis. Even a supervisor may become blind to the speed (see e.g., Delamont et al., 2000; Philips \& Pugh, 2005). The quick pace does not harm or bother those who are able to proceed with a sense of direction and comprehend that scientific thinking, studying, and understanding the complicated phenomena require long-term conversance, demanding consideration, and reflection. Still, during the $\mathrm{PhD}$ research, uncertainty about the direction of one's road haunts every PhD student occasionally (see also Costley \& Stephenson, 2009). How and in what order should one proceed? Is the text sufficiently scientific or scientifically convincing as a whole? The ability to ask for help is crucial.

What is this disease called? The symptoms: I am unable to produce new text and also the previous seems hollow and trivial?

A $\mathrm{PhD}$ student relies on the supervisor at the beginning and during his or her studies. The supervisor has to make sure that the prerequisites for a doctoral thesis will be met. For the student, uncertainty may also emerge from a doubt of whether the whole doctoral thesis will be finished or one's resources are enough to achieve that at all (cf. Golde, 2000).

I feel mostly empty: I feel like having given my all. What else could I do since I have looked through the revision tips several times?

The expression of doubt is crucial, and it can lead to new hope if the supervisor is able to provide encouragement and support (see also Cullen, Pearson, Saha, \& Spear, 1994). Supervision is interaction with a variety of response elements: the expressions of surprise and identification, advice, help offers, objections, answers that aim at normalizing, and interpretation. Interaction may also turn into a struggle of opinions, in which a supervisor's questions and views are accepted, reflected, or rejected. Admitting one's own obliviousness, accepting the state of wondering, and the ability to pose questions and problems are the bases of all learning, and the dissertation process is continuous studying to a doctoral student and a supervisor as well.

The most inspiring moments in the research work are the insights and even the smallest theoretically or practically relevant findings or discoveries that occur during the process. Finding workable solutions and confirming a clarifying direction may produce enthusing experiences of engagement. The moments of success and the experiences of one's own proficiency are motivating (Pintrich \& Garcia, 1994; Ryan \& Deci, 2000). 
Skillful supervision consists of appreciating and supportive interaction, but along with the emotional tone, the structure of a supervision conversation is of great importance (Atkins \& Brown, 1988). From PhD students' point of view, their concerns should be handled promptly. The supervisor should answer immediately when it is a question of facilitating or eliminating problems, offering solutions, or just confirming the selected way.

Warm thanks for your quick feedback - I am speechless with surprise and abashed. I was so scared.

A doctoral thesis has to meet the high academic requirements. Achieving this goal rarely happens overnight. Regardless of the pace at which a $\mathrm{PhD}$ research advances, students have to learn to tolerate criticism, corrections, and suggestions of how to improve their work (see also Cullen et al., 1994). More often than not, students may consider their theses ready and find out that there is still plenty to do. Although a supervisor would assure a student that a thesis is going to improve when the feedback is addressed and the thesis revised, the PhD student may still feel disappointed, annoyed, and insulted. Some find it hard to hear from the supervisor that the text has to be shortened, condensed, inserted, or improved. And still, the same will happen again, when the external examiners read the thesis and give their comments. In this sense, too, writing a doctoral thesis leads a student to his or her limits; not only do they have to patiently read and accept even critical feedback, but they also have to be ready to revise the thesis according to this feedback. Therefore, giving positive reinforcement and appreciative feedback for successful solutions is also important because positive feedback keeps motivation high and encourages to continue with the not so pleasing revision tasks along the process (Costley \& Armsby, 2007).

When I finally received favorable review statements, it was the biggest joy, and then I started to be nervous about the actual public examination.

The acceptance of the doctoral thesis leads to the final steps of the process, which is slightly different in different countries. In Finland, the process culminates in the public examination in which the $\mathrm{PhD}$ student has to defend his or her research in public. The opponent is an expert professor in the field.

\section{(5) The final step-graduating as a doctor}

Common to all doctoral students are their own change and strengthening. Doing doctoral research and defending it in public represent a mental border crossing. Getting through this challenge assures one of one's own expertise and gives resources and courage to race to new challenges. Expertise increases, self-confidence strengthens, and responsiveness may increase as well.

I will not ever forget the day of the public defense, and I was content with myself: I was able to accomplish this. 
Returning to everyday life after graduating as a doctor is not necessarily just sunshine (see also Golde \& Walker, 2006). Even if one does not find new work tasks that correspond to one's education, postgraduate studies have anyway provided one with readiness and expertise to develop one's own work, and the imprints will appear little by little.

Even if a dissertation process did not bring any concrete benefits, its being so immemorial and rewarding is undeniable. After writing a doctoral thesis, a $\mathrm{PhD}$ student is not the same, and something has permanently changed.

A doctoral thesis is the highest grade academic thesis. It is proof of a doctoral student's special expertise and learnedness and his or her merit. However, hardly anyone achieves the goal of becoming a doctor by oneself or alone. A doctoral student's family, friends, employer, working conditions, and the library and other support services are of primary importance to the progress of a doctoral thesis. In addition, the companionship of other doctoral colleagues, scientific conferences, and postgraduate seminars may provide special support and help. The significance of a supervisor is remarkable. It is to a supervisor's credit to make a doctoral encouraged and stretch to a top achievement. It is the most far-reaching and rewarding thing in supervision.

In academic education and supervision, the cognitive processes are at centre stage. In addition to the previous, emotions belong essentially to $\mathrm{PhD}$ education. The joy of knowing and the fear of failure, excitement and relief, the ultimate efforts and overwhelming delight: all these are placed in the doctoral students' stories. Emotions, knowledge, and learning intertwine (Rantala \& Määttä, 2010). The emotions affect the energizing of the action, setting a goal, and a learner's attentiveness (Pintrich, 2003). Positive emotions enhance problem-solving skills and logical reasoning, creativity, and social decision making (Rantala \& Määttä, 2010) and increase self-efficacy (Elias, 2004).

In all, a PhD research process appears as a one-of-a-kind series of events representing a top performance at its best. Next, we will introduce PhD students' descriptions of how their paths resemble top performance and how they perceive successful $\mathrm{PhD}$ processes.

\section{PhD students' descriptions of their research process as a top performance}

Along with lifespans, people become rewarded for excellent performances, for example, at school (e.g., straight-A graduates; see Salmela \& Uusiautti, 2013) or at work (e.g., employee of the year nominees; see Uusiautti \& Määttä, 2015). When people work and study and act at their limits, they can reach top performance. In this chapter, we consider a doctoral dissertation as an accomplishment that can be seen as an example of top performance that only a few can achieve in the university context. In this chapter, our purpose is to analyze the individualspecific requirements and context-bound features enabling the emergence of top performance within the context of a dissertation process. We aim to answer the 
following questions: What are the individual-specific requirements for top performance? How does the top performance manifest itself?

First, we introduce findings regarding doctoral students' individual resources required in top performance. After that, we describe how the students described the experience of acting at their limits through the conceptual framework of an optimal, autotelic experience flow.

\section{INDIVIDUAL-SPECIFIC REQUIREMENTS FOR TOP PERFORMANCE}

As the introduction of the concept of performance showed, many elements are involved in top performance, and the use of human resources depends on both context-bound and individual features that can vary considerably from one situation to another. The results showed many ways to categorize human resources. We will introduce a grouping of four elements that each illustrate a separate but yet interconnected area of human functioning (see also Määttä \& Uusiautti, 2014).

First, there are positive emotions. Joy and contentment, optimism, being appreciated, and feeling of security create a positive mood, a fundamental positive attitude that affect positively well-being at work in numerous ways (Ghorpade, Lackritz, \& Sing, 2006; Huang \& Viert, 2004).

The feeling that I will survive, I can and I will show it was an enormous force of going-ahead.

Likewise, many $\mathrm{PhD}$ students mentioned how 'worries and insecurity turned into joy', and how the dissertation process was not that difficult after all.

\section{I have been surprised at how easily it all seems to run.}

Positive feelings enhance intellectual thinking and problem-solving skills, decrease the defending attitude, and also improve memory, and helpfulness. The importance and potential of this may seem surprising because the feelings of happiness are so simple and common in nature (Isen \& Reeve, 2006). Another reason why beneficial effects of positive feelings may seem surprising is that people do not usually look for reasons or explanations when things go well. Positive emotions function as emotional resources.

Second, people live in the network of human relationships their whole lives. Many people find the meaning of life within the framework of relationships. For example, Berscheid (2006) claims that understanding human behavior has suffered because of forgetting this fact. However, most behavior takes place in the context of human relationships. Many PhD students described how they had a chance and privilege to lean on the familiar social community that supported them in their dissertation process:

I have the network ready, and everyone is happy to participate, almost as if they were putting out the red carpet for me. 
Everyone needs intimate relationships that provide appreciation, support, recreation, and protection. In a school context, Pyhältö, Soini, and Pietarinen's (2010) study showed that the possibility and ability to use the social resources provided by the environment (especially when combined with a sense of active learning agency) could protect students from, for example, experiences of anxiety and emotional distress (see also Billing et al., 2014).

Likewise, the agony of laboring alone is eased by the new supportive people whom one meets during the dissertation process. The research work involves a number of new people who doctoral students familiarize themselves with, and long-term friendships may spring up between people who are experiencing and going through the same process. Good interaction skills, empathy, flexibility, patience, caring, and interest are significant social resources that support the creation and preservation of good and close relationships (see also Thompson \& Prottas, 2006).

Third, great plans and performance or long-term goals cannot be achieved without self-appreciation, perseverance, and commitment as well as the ability to control and channel impulses (Gross \& John, 2003). In this study, several PhD students mentioned how writing a doctoral thesis is basically like ordinary drudgery, systematic working that proceeds step by step:

Writing a doctoral thesis requires rigorous work. The files and references have to grouped, noted, and kept in order. You just have to sit, read, and write persistently.

The strength of character, self-discipline, and ability to control impulses are important features for good performance (Cullen, Gentry, \& Yammarino, 2015). Likewise, optimism has a clear connection to it because, among other things, optimism involves the ability to set reasonable goals, to achieve these goals, and to use efficient learning strategies (Gillham \& Reivich, 2004). According to Carver and Scheier (2005), optimistic people achieve their goals because they organize their actions in an intellectual way. Proactive attitude (as opposed to reactive) (see Uusiautti \& Määttä, 2011, 2015) also represents such cognitive resources. Indeed, many doctoral studies arise from such a proactive action, a need for research that emerges from practice.

Finally, being able to use one's strengths provides the sense of meaningful doing (see Csikszentmihalyi, 2008). Therefore, it is also important that people are able to do those things that they can, to fulfill themselves and use their talent, to create and develop. Still, it may be difficult to detach oneself from the grasp of writing a doctoral thesis. Having a break may be striking or depressing even though 'the saddest thing would be to let the doctoral student think that something is possible when it is not' (a supervisor's notes).

Locke and Latham (1990) have launched a concept of a 'high performance cycle'. The concept helps understanding the nature of a dissertation process, too. According to their idea, if the challenge includes expectancy of success, high performance is guaranteed assuming that the person is engaged to the goal and 
receives adequate feedback and that situational factors do not affect the performance considerably (see also Uusiautti, 2013). Similar findings have been learned from the various education levels (e.g., Gilpin, 2008; Green et al., 2012; Oades, Robinson, Green, \& Spence, 2011) and hobbies (e.g., Carruthers \& Hood, 2005 ), too. These kinds of resources are functional resources.

When a human being is able to get the most of his or her resources, he or she is likely to get positive feedback and recognition from others (McKenzie \& Schweitzer, 2001), achieve high performance, and have increase in his or her selfappreciation. This represents the true opportunity of self-fulfillment. During the dissertation process, students are able to proceed with a sense of direction and realise that scientific thinking, studying, and understanding the complicated phenomena require long-term conversance, demanding consideration and reflection:

I have learned that things become apparent progressively. One has to test different thoughts, study the literature, and the data. One has to reflect on them and match up over and over again.

However, the holistic nature of human functioning necessitates that the resources have to be protected and nurtured to develop or flourish. Both the supervisee and the supervisor need to rest, too:

Thank you and sleep well, my supervisor, since you confirmed those to me! This is interesting processing. I have been able to do plenty of specifications today.

As riveting as a dissertation process may be, the students' positive and healthy development is threatened without the protective leaves of sleep, nutrition, and physical exercise. They make the use of inner resources possible, which concerns a dissertation process, too. It can be quite a life-changing experience as whole as described by one PhD student:

If I were to name any positive sides of this hard work pace, I would say I bave quit smoking by oversight since I do not have time for it anymore.

\section{RESOURCES AND OPTIMAL EXPERIENCES}

When considered as a top performance, a dissertation process requires several elements of human resources. These are apparent in the PhD students' narratives, as the previous result chapter showed. Top performance is also closely related to a phenomenon called flow, and the data showed that this experience was familiar to the research participants. In this chapter, we introduce the top performance of a dissertation process as it manifests itself through the phenomenon of flow.

Flow is a subjective state of feeling control - or better yet, feeling that you can act without any control, without hindrance (Csikszentmihalyi, Abuhamdeh, \& Nakamura, 2005; Gardner, Csikszentmihalyi, \& Damon, 2001). Features such as 


\section{Successful university students}

gender and cultural norms affect the experience of flow; however, here, the focus is on the experience of flow as the manifestation of top performance.

Based on the narratives and email conversations, many of the participants had visited 'a weird planet', 'the spaces of mind', or 'had alienated themselves from the surrounding world'. The flame of working and doing as well as the feeling of mastery had riveted them, bringing downright the endless feeling of the joy of work.

Doctoral students described experiences that resemble Mihaly Csikszentmihalyi's (2008, pp. 49-67) components of flow. Flow is usually experienced when goals are high and feedback is immediate and fair. In addition, the task at hand, the doing the person is committed to, has to include continuous challenges that match her or his skills. Flow is equivalent to the feeling of absorption (Csikszentmihalyi, 2008; Schaufeli, Salanova, Gonzalez-Roma, \& Bakker, 2002). This means that one concentrates fully on what one is doing instead of thinking about something else; action and awareness merge. Clarity of goals and immediate feedback lay the foundation of this experience.

I was told that we had a lovely hot summer, but I did not have time to notice that as I was excited about sitting at my computer. A surprise visitor marveled at me as I was wearing thick slacks, a sweater, and wool socks although it was really hot weather!

Flow can emerge through challenging activity that requires skills if one's skills and abilities match the task at hand. This can lead to high motivation and activity, but first, uncertainty, self-protection, and even mystical expectations that are involved in a dissertation process have to be conquered. Indeed, in flow, one always knows what has to be done, and an enjoyable task always has clear goals; a goal of dissertation process is to finish doctoral studies and compile the doctoral thesis. With this in mind, a PhD student can analyze his or her work and its proceeding in the light of the set goals:

Writing a doctoral thesis requires self-discipline. I find my intermediate goals functional; I try to stick to them. I take small steps to finish various parts of the study.

In addition to the fact that one knows what has to be done (the goals), flow always requires information about how well one is doing, and maintaining flow in unresponsive context can be difficult or impossible. The supervisor is the most important feedback provider for the student as the following emails sent to a supervisor shows:

Oh wow. That is it! Thanks. Now I see it.

The aforementioned elements of flow essentially enhance concentration on the task at hand. What follows from the merging of action and awareness is that distracting issues do not bother when doing the flow-providing work. The work pace may be hard labor in practice or use of mental energy and attention. 
Often, the experience of working at one's limits leads to a paradoxical sense of control. The most enjoyable experiences allow people to have a sense of control over their actions. Working on a doctoral thesis encourages doctoral students to concentrate and to prevent interruptions. Not many complain about fatigue; they merely talk about 'the flame of working' and 'drive': 'Now I am going strong'. This means that rather than thinking of the actual doing, they feel the possibility of control.

I do not understand the spree that is going on. I am so unusually impatient and unable to dissociate myself from this.

One of the most common descriptions of optimal experiences is the perception of time and how it does not seem to pass in a way that it ordinarily does. Many people have experienced the changes in time: sometimes it goes faster, and usually this happens when doing something enjoyable. To perform at one's limits, one has to become free 'from the tyranny of time' as expressed by Csikszentmihalyi (2008, p. 67) himself.

Thank you for being so patient. I have suspected that you will already close the door. I am so annoyed. Now that I have rewritten the table of contents, I became inspired again. Nor do I know what the time is.

(Email to the supervisor; sent at 2.23 a.m.)

Total absorption tells about the loss of self-consciousness, which is an interesting part of flow because it eventually leads to increased self-consciousness and self-awareness - being alone with one's self. The foundation of the loss of selfconsciousness is in the clear goals, stable rules, and suitable challenges, and therefore, they involve low risk for the self to be threatened.

\section{I do not know myself. Am I really me or someone else?}

At the same time, when being wrapped up in one's doing, flow requires a very active role for the self (e.g., McWilliam, Dawson, \& Tan, 2008). This means that to fully use one's abilities and even exceed one's skills, one has to have a good self-conception, a profound understanding of one's self (Hogg, Abrams, Otten, \& Hinkle, 2004). In the school world, at first glance, this can be easier said than done, but there are means that can be used for creating such optimal learning conditions (Ryan, Soven, Smither, Sullivan, \& Vanbuskirk, 1999)

\section{Understanding the meaning}

According to our analysis, the dissertation process, when considered as a manifestation of a top performance, can lead to the perceived meaningfulness, which actually is one of the basic tenets of positive psychology (Seligman, 2002, 2011). Likewise, its connection to flow is evident as shown in the PhD students' descriptions of becoming riveted by the dissertation process. This notion is crucial 


\section{Successful university students}

because positive experiences, such as flow, can enhance students' productivity, engagement (Hakanen, Perhoniemi, \& Toppinen-Tanner, 2008), coping and problem-solving skills (Carver \& Scheier, 2005; Judge, Locke, \& Durham, 1997), and overall well-being (Schunk \& Pajares, 2005). Most important, flow also is involved with one's skills, which also are closely connected with satisfaction and sense of meaningful doing.

Action at one's limits is also a matter of self-awareness and authenticity (Gardner, Avolio, Luthans, May, \& Walumbwa, 2005). This is how an open and confidential relationship with a student can be built. Likewise, in caring supervision, the student can be oneself and fully engage to the process knowing that she or he is appreciated and accepted as is.

In this chapter, we focused on the elements of top performance from a select point of view, introducing a dissertation process as an example of such optimal action at one's limits. As the analyses showed, top performance is the sum of many factors, and not just dependent, for example, the individual student's abilities. Actually, support and guidance by the important people surrounding the student seem play almost equally important role. Good supervision contributes to not only to $\mathrm{PhD}$ students' optimal performance but also to supervisors' work by providing them with positive teaching and supervision experiences, initial excitement, perceived successes, and positive feelings (see also Csikszentmihalyi, 2008; Isen \& Reeve, 2006). We will discuss this in detail in Part 3.

\subsection{Students' resources in university studies}

\section{Study success tells about well-being, too}

Students want to gather study points and grades and advance in their studies. However, study success and high achievements may reflect students' well-being and health, too (Eide \& Showalter, 2011; Uusiautti \& Määttä, 2015, 2016). Well-being makes study processes smoother (Rauscher \& Elliott III, 2014), but on the other hand, if studies become prolonged or overwhelming, students' quality of life decreases (Cowan, 2011; Hansen \& Lang, 2011).

It is obvious that students' study skills and attitudes and personalities have an influence on their way of studying and opportunities of succeeding (Duff et al., 2004; Määttä, Uusiautti, \& Määttä, 2016). Previous study success (Busato, Prins, Elshout, \& Hamaker, 2000), even experiences in elementary school, have their own influence on university studies (Hébert, 1993). In all, the smoothness of study processes is a sum of several factors (Määttä, Uusiautti, \& Määttä, 2016).

The purpose of this chapter is to describe what kind of study attitude is needed for the successful completion of a university degree as described by graduated masters and students studying in the master's level. Hardly anyone's study process is straight and lacks adversities. Overcoming difficulties and hindrances is part of the completion of an academic degree. What do university studies require from students? And what are successful graduates made of? 


\section{What are university students' most important resources?}

The following 12 themes illustrates students' views of the most common means and resources of completing a university degree as described by students themselves.

\section{(1) Self-confidence and self-respect \\ I will survive, and I can do it.}

Students have to be certain of and trust in their abilities to perform university studies. Their previous study experiences may not necessarily have supported or strengthened their learning skills, and experiences of failure can haunt their minds. Hardly anyone finds studying or learning something new easy. If students have doubts about their ability to perform or cope with studies, it is important to turn to teacher students and talk about these issues.

Likewise, it is crucial to reflect the state of one's self-respect. Everyone working toward a university degree has experiences that strengthen their skills and their self-efficacy beliefs. Self-esteem and self-respect tell about the students' own beliefs and expectations of their abilities to perform well studies included in the university degree. This understanding about oneself as a student develops alongside studies.

\section{(2) The decision to start studies and to continue them}

I roll up my sleeves and start working.

The first study points should be completed as quickly as possible at the start of university education. This can ignite the desire to graduate promptly and to pass also courses that seem difficult or otherwise unpleasing. Some students find it better to first take courses that match their skills and interests the best. Some others like to complete the difficult phases at once because they become convinced of their ability to perform studies efficiently and with good results. Easy courses and phases may follow along by themselves.

Especially, in the phase of doing an academic thesis, the student's own decision of starting the work is the most crucial one, as mentioned also when discussing doctoral studies. It is not very difficult to find reasons to postpone this demanding part of studies. Therefore, it is important to be aware of possible excuses and to control them.

\section{(3) Appreciation of the privilege of being able to study}

I am granted with the privilege to study a master's degree.

In Finland, university education in free. Therefore, parents' or one's own wealth does not determine the opportunity to study in universities. The intellectual 
capital and development of learning and expertise can be a reason for great respect. Many students can be thankful for becoming accepted as a student, for having a chance to progress in life to one's fullest potential, and for being able to see the world from the various viewpoints provided during their education. A university degree is appreciated by others, too, and the completion of the degree tells about one's capabilities and talent. Not everyone has what it takes to graduate from a university.

\section{(4) Courage}

I enter the new world with a positive and open-minded curiosity.

The world of university studies is new and different from earlier study experiences. Sometimes hard work is not enough, and sometimes the wish to learn is not enough. One's skills are tested, and the forthcoming study years include plenty of unknowns. Trust in one's enormous potential can help one seize tasks that are outside from one's comfort zone but that can introduce new dimensions and show ways of better understanding reality.

\section{(5) Patience}

I tolerate it that sometimes studies go on easily, sometimes they tangle, and there is no free ride to a master's degree.

Studies do not always go on as wished, and hindrances are not always the student's fault. However, the study processes involve situations that the student can have an influence. For example, long waiting times for examination scores or criteria for evaluations can be found out by asking, being active, and making sure that the student has done her or his best to ensure fluent studies. Actually, there have been and will be plenty of reforms that originate in students' ability to call for better solutions. For example, flexible online examinations, various forms of online teaching, and online textbooks have been included in studies based on students' suggestions.

\section{(6) Enthusiasm}

\section{I can do something new and significant.}

University studies offer chances of creating something new. When studying, students can come up with innovative viewpoints and new, creative solutions to traditional ways of acting. In the academic world, strong expertise and traditions can become a burden and make people blind to new solutions. Students can break the limits. Students' doors are open to many directions, and the ability to question their own and others' stubborn opinions can promote enthusiasm and increase creativity. Many graduates remember occasions that let them test their 
own limits, become inspired and succeed, and strengthen their sense of being able make a difference.

\section{(7) Tolerance of insecurity and criticism}

Nothing great can be achieved easily.

Uncertainty and even disappointments are part of study processes that aim at great achievements. The ability to be happy of successes has to be consciously practiced, in addition to the ability of surpassing obstacles.

It is important to notice and focus on successes and accomplishments and to realise that they also include errors, mistakes, and nodes. One can learn from them and progress to new achievements. Therefore, it is also important to thank oneself for good results instead of thinking or worrying about hindrances or adversities.

(8) Good reading and writing skills

I develop as a writer by writing and as a reader by reading.

Writing increases one's capacity, and simultaneously one's learning abilities and skills develop. This happens phase by phase when moving on from one course to another with the help of guidance, feedback, and self-evaluation.

\section{(9) Normalizing overwhelming expectations}

\section{Learning new is based on the previously learned.}

Proceeding from one degree to another is quite normal - like a master's degree is a natural continuum to a bachelor's degree. It does not demand any new, superficial skills, and therefore, its demandingness should not be overestimated. The intellectual capital is gathered little by little by increasing earlier knowledge - perhaps by revising, molding, and complementing it, too.

\section{(10) Good scheduling}

I set numeric goals and a plan of progress to my studies.

Students who can set goals and plan a study schedule that is not too tight and not too loose are the most successful. A careful study plan should be done so that it lists all required studies, estimations of time needed to complete them, and their chronological sequence. It is also good to think about which studies are mandatory, which studies are options, and what other choices there are. In Finnish universities, students can include such studies in their degrees that correspond to their own interests and promote their special expertise. 


\section{(11) Taking care of one's well-being}

I enjoy what life offers.

Student life should include hobbies and relaxing free time that support coping with studies, even though studies include many pressures and obligations that have to be fulfilled. Still, studying does not prevent joy and opportunities to do things that are pleasing. At its best, studies offer positive experiences and not just toil.

Other areas of life also provide sources of well-being that students have to take care of. In this study, many students mentioned physical exercise as a free time activity that improved their mood and prevented fatigue during demanding study processes. As a whole, hobbies, such as sports, provide experiences of happiness and joy at many levels that improve students' well-being. For example, Crystal Wu (2014) has explored the elements of well-being in sports, leaning on Prof. Seligman's PERMA theory, and concluded that it is possible to pay attention to and enhance one's well-being through sports as well.

\section{(12) Good social relationships}

\section{I take care of my family relationships and friendships.}

A balanced study life means that students arrange time for their families and friends, too. Good, positive relationships are support and security in good and bad times. Social support and encouragement and just being together and in a good company are extremely important supporters of learning. And even one good friend is enough.

\section{The Garland}

The Finnish universities have a festive tradition in which masters', doctors', and honorary doctors' degrees are conferred. The conferment is aimed at everyone who has graduated as a master or doctor and whose degree is approved before the conferment regardless of the year of graduation. As a symbol of the conferment, masters get garlands. It is adopted from the ancient Greek Apollo, who was the god of singing, poetry, and light, and who was wearing a garland in his head after the father of his loved one, Dafne, turned his daughter into a laurel tree because he did not approve of Apollo as her suitor. A laurel tree became a symbol of peace and immortality. In the conferment ceremony, the garland, made of laurel leaves, symbolizes knowledge, education, and free arts. It is a mark of a significant achievement.

The requirements of an academic degree can be illustrated as a garland figure (see Figure 2.2). Each laurel leaf represents one of the themes introduced as the various dimensions of study processes at universities and form a useful presentation of the factors that should be considered when aiming at supporting students' smooth study paths. 


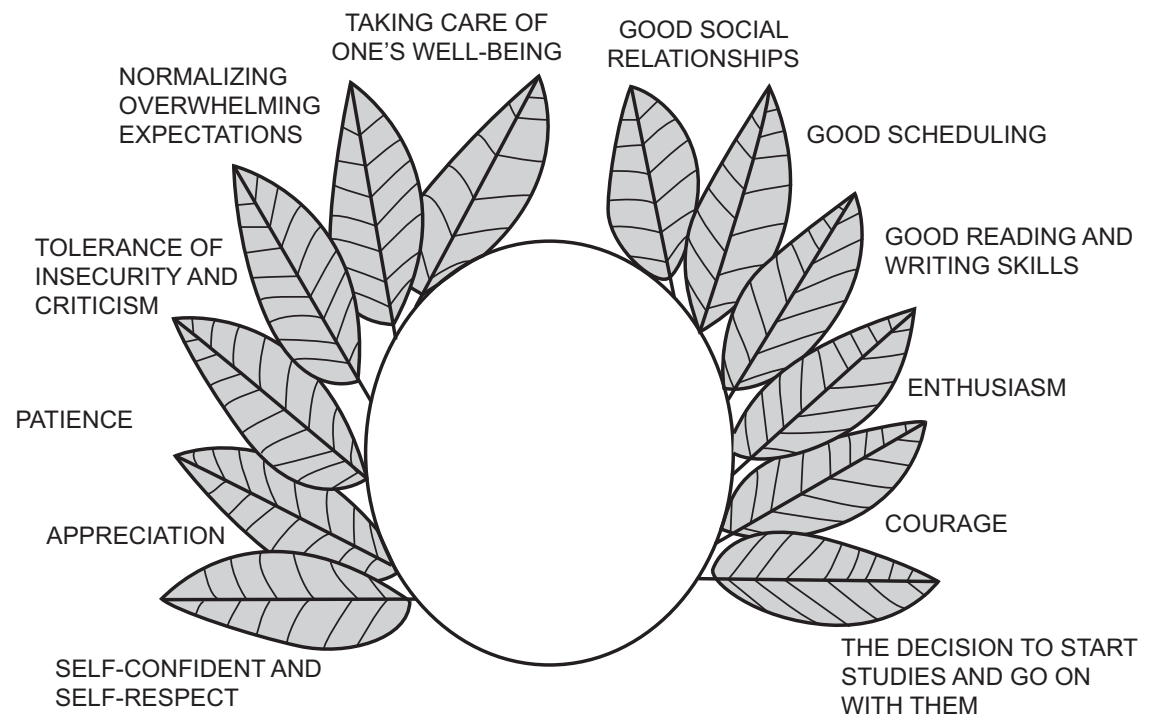

Figure 2.2 A master's garland (adopted from Määttä \& Uusiautti, 2016, p. 7)

\section{Social media and internet-based solutions as university students' resources}

One topical resource in university studies is the way of arranging teaching and socializing with others. This topic was touched upon earlier, too, but here highlight it specifically from the perspective of students' resources. There are increasing studies showing the benefits of peer support networks that make communicating with others easier and that are encouraging further research and applications for such usage (Oldmeadow, Quinn, \& Kowert, 2013; Przybylsk \& Weinstein, 2012). For example, it has been proven that interactions with peers who are successfully coping with their problems are more likely to result in positive behavior change in others (Solomon, 2004). In Takahashi et al.'s (2009) study, participants felt empowered by giving online peer support to others in social network services (SNS). The findings are supported by Vaarala et al. (2013) reporting that online peer support can be very important for university students who are coping with loneliness.

The role of internet and online communication has been known already for a while in adolescents' lives (e.g., Scherer, 1997). In education contexts, this area of life must be acknowledged and taken seriously (Silius et al., 2010). Social media provides many opportunities for education: it can function as a learning environment; a student peer network and a medium of learning new, relevant, and topical skills. Thus, SNSs can be used for education and in education more efficiently. 
When writing this chapter, we were interested in knowing how Finnish university students consider SNSs, especially education-wise. The purpose is to increase understanding of the nature of using social media and its possible influence on students' lives and in this way support their success in studies (see e.g., Määttä \& Uusiautti, 2012; Uusiautti \& Määttä, 2013). Indeed, international research on people's behavior in social media has exploded and provided numerous points of views that are sometimes even contradictory (see e.g., boyd \& Ellison, 2007; Caers et al., 2013; Haythornthwaite, 2005; Rohn, 2014). What is certain, however, is that SNSs have influenced and will influence human beings' social lives. Some studies suggest that people who actively participate on Facebook are more likely to experience connectedness and feel happier (Valkenburg, Peter, \& Schouten, 2006). Students with lower levels of life satisfaction tend to seek to participate in online networks to increase their personal well-being (Ellison, Steinfield, \& Lampe, 2007).

Steinfield, Ellison, and Lampe's (2008) study combines the idea of social capital with human well-being and SNSs. Their viewpoint rests on the idea that social capital is illustrated in social relationships as presented by Bourdieu. Bourdieu (1996) divided capital into three types: cultural, economic, and social capital. The first refers to an individual's concrete, financial capital, possessions, and ownership (money, things, income, and wealth). Cultural capital means the ownership of cultural products, a certain way of life and making choices, and the ability to make use of and produce culture (including education). Social capital is the entity of those actual and potential resources that are connected to social relationships and the ability to mobilize people (Bourdieu, 1984). Social capital is immaterial and connected to mutual recognition and appreciation among individuals.

How is social capital connected to social media? Notwithstanding, social ties make a key feature of individuals' life satisfaction (Kahneman \& Krueger, 2006), and in today's world, social media has become an important channel of increasing social capital (Ellison et al., 2007). Kavanaugh, Reese, Carroll, and Rosson (2005) distinguish two types of social individuals in SNSs: bridging individuals, who create and organize networks, and bonding individuals, who establish close relationships with others, for example, within a network. The researchers' findings suggest that bridging individuals can enhance social relations and information exchange and increase face-to-face interaction via SNSs. All this helps to build both bonding and bridging social capital in communities (Kavanaugh et al., 2005). Bridging social capital refers to loose connections among individuals who may provide useful information or new perspectives for one another but typically not emotional support like bonding networks do. Likewise, Ellison et al. (2007) discovered that the use of social media has a strong association with social capital and interacts with measures of psychological well-being in university students. In all, SNSs thus make an important channel of establishing and maintaining social relationships and have become an important element of human well-being and happiness as well (Saslow, Muise, Impett, \& Dubin, 2012; Seder \& Oishi, 2012).

We analyzed what kind of benefits university students perceive for social media, how they use them, and how they think they could be used. What kinds of benefits 
do university students perceive in the usage of social media? What kind of social capital does social media produce according to university students' opinions?

BENEFITS OF THE SOCIAL MEDIA ACCORDING TO UNIVERSITY STUDENTS'

OPINIONS

When asking university students how they perceive the opportunities of using social media more efficiently, their viewpoints varied from 'no more possibilities/the social media has reached it top usage' (11.1\%) to detailed descriptions of various utilization possibilities $(56.7 \%)$. Those who were able to see further opportunities for the usage of SNSs could be categorized roughly into four categories based on the themes emerging from their answers. We will introduce their viewpoints next.

Most ideas concerned the use of social media in education. Students were certain that the opportunities of using the social media in education are 'limitless' (Student no. 88). They mentioned study groups that could enhance cooperative learning; either students or teachers could form groups around a theme or a school subject in which students could share and discuss the study theme, develop projects or ask questions and give answers. Teachers could post assignments and give directions via SNSs, and students would have access to these tasks from anywhere and anytime. Other study-related information, such as scheduled exam dates or information about excursions, could be posted in the social media networks.

The social media can be well employed, for example, in education. Students create environments for themselves in the social media, and share information and their experiences there.

(Student no. 77)

It could be probably used in teaching. Courses could have close communities that would enable students' interaction also out of school hours.

(Student no. 7)

Indeed, social media was considered an important future channel of interaction at school, and some of the students mentioned that it would be necessary to not only use SNSs at school for better and more efficient interaction but also to teach modern interaction, the interactive side of it, which has become increasingly important in today's life to everyone.

Opportunities to teach people to interact virtually, and it would develop people's writing and influencing skills as well.

(Student no. 57)

It could be used more at work and school, because it offers good possibilities for being in contact with people.

(Student no. 73) 


\section{Successful university students}

Furthermore, interaction via SNSs in education would not be limited to just students and teachers but would include also parents and partners outside school, such as local entrepreneurs. The social media would thus enhance knowledge of the local and global environment and society; SNSs make learning environments of their own.

The social media could be used more in the home-school cooperation.

(Student no. 77)

It makes global interaction possible at school.

(Student no. 17)

The social media can make use of other people's knowledge. You can learn via SNSs.

(Student no. 5)

The second most important future usage of the social media mentioned by university students was its possibilities for enhancing bonding and providing peer support. Students emphasized the opportunities of bonding as well as building and learning communality in social media. This advantage was reasoned with the easiness of contacting and interacting with others via SNSs and thus the incomparable ease of creating networks.

For stirring experiences of bonding!

(Student no. 57)

People could use the social media more rationally especially for networking, and, thus, considering their future, too.

(Student no. 82)

An especially invaluable feature of SNSs was, according to students' opinions, peer support groups that could be used better and more widely in the future.

It is particularly good for peer support groups that kind of offers anonymity but still you can talk and share, and give and receive support from people experiencing the same.

(Student no. 72)

It can provide a support network, e.g., for weigh management, new acquaintances, group activities, peer support, online second-hand shops, village communities, etc.

(Student no. 54)

In all, bonding and communality, as well as group activities, in social media were considered important ways of finding positive experiences. In today's world, 
people spend plenty of time on SNSs; therefore, the human ingredient, sense of togetherness, and happy experiences provided via social media are becoming increasingly more important for human well-being. However, it is not self-evident that everyone can benefit from social media like this. Therefore, education can be crucial:

In my opinion, an individual people has the opportunity to get positive experiences from the social media, if the individual knows how to realize the opportunities.

(Student no. 71)

Some of the students considered that social media could be used more effectively for information sharing and increasing awareness about social issues and other topical events and matters. They emphasized that plenty of important information can be missed without SNSs where one can learn about something that is not reported by the traditional news media. In this way, social media also could function for giving voice for those treated unfairly, and therefore, for doing good.

The social media could be used more for bringing out issues needing a change. It is a place where you can reach plenty of different people from different places, which makes it possibilities for good - quite significant.

(Student no. 45)

Informing about good things and soft values and reaching masses in cases of emergency, making influencing on social matters easier, and letting the voices of people facing inequity heard.

(Student no. 49)

The rest of the students focused on the usage of social media in work. They referred mostly to marketing and communication opportunities but also had noticed the possibilities for idea sharing and cooperation and for finding a workplace. Enterprises not appearing in SNSs were considered outdated, and certain professionally oriented social networks were seen as important in finding employment and creating work-related networks.

The possibilities of marketing and communicating are limitless - not many enterprises or communities know how to make use of it! Social media is, however, an easy way of reaching a big audience; when used in a right way, it makes a powerful means.

(Student no. 48)

When summing up university students' experiences and opinions on the utilization of social media, one factor becomes the most essential for their well-being: its social benefits. This is in line with the findings about two fundamental reasons for joining social media: (1) the need to belong and (2) the need for self-presentation 


\section{Successful university students}

(Nadkarni \& Hofmann, 2012). Likewise, Lee, Yen, and Hsiao (2014) showed that, among university students, experiential value is found to be most significant in social media; users seemed to mostly fulfil their psychological needs, such as sharing useful information and receiving enthusiastic replies or praise, from their social contacts on SNSs.

In all, the students' evaluations about their reasons for using social media were mostly connected with social relationships and interaction. Most of the students justified the use of social media with an increased and easy interaction with friends and relatives even around the world (see also Rohn, 2014). The students described that their main action on SNSs is focused on social relationships and friendships and that the networks existing in social media are one of the main reasons for using social media.

SNSs is especially important for making social interaction easier and constructing communality.

(Student no. 33)

We also wanted to know how the university students thought social media could be used better or more efficiently. In these answers, too, their emphasis was on communality, bonding, group activities, and peer support; they all can be seen as components of social capital. Although some students talked about various methods of using social media, for example, as a part of education or to create special focus groups, some others referred to possibilities of enhancing awareness and sharing experiences and information. All these possibilities were connected to the need and wish to work for everyone's good, to improve social interaction, and to provide positive communal experiences to each other.

What can be then said about the social capital constructed in social media? How does it boost students' well-being or their study success? Students considered social media as a way of enhancing the positive sense of togetherness and constructing communality that are based on the internet. The sense of giving and receiving support, thus, differs from what one might have in real-time face-toface encounters but is not any less important. Especially when thinking about the increasing demands on individualism and self-directed action necessitated from today's people by schools, work life, and other areas of life, it is all the more important to discuss the social opportunities and benefits of modern lifestyles. Furthermore, as the students highlighted, bonding does not mean only support of special interest groups but also information sharing in general and wide educational and work life connections. They also mentioned influencing and active civic participation (cf., Valenzuela, Park, \& Kee, 2009).

Therefore, social media and internet-based solutions appear as university students' resources at many levels. First, social media can be considered a new type of a learning environment, providing both formal and informal learning and education opportunities (e.g., Niemi \& Multisilta, 2014). Not only did university students perceive social media as a suitable and functional place for discussing themes studied at school with peer students and teachers but also with others. 
According to Mason (2006), this type of possibility to provide timely and context-bound feedback in education has the potential to deliver a positive learning experience (see also Selwyn, 2009). Furthermore, one of the crucial problems in university-level studies is that the beginning of studies is the most difficult for many students also because they do not yet know their peers or teachers (Määttä \& Uusiautti, 2012). SNSs could be used for lowering the doorstep for contacting and familiarizing them. Furthermore, SNSs could be used for learning from other relevant people or communities about the theme at hand, for example, by inviting representatives from various workplaces to tell about their experiences and viewpoints and including an opportunity to ask questions from them. When used as a learning environment, tasks, schedules, and other relevant information about studies could be shared through SNSs.

Some pedagogical applications are already introduced, such as a personal learning environment, which is a potentially promising pedagogical approach for both integrating formal and informal learning using social media (Dabbagh \& Kitsantas, 2012). The study by Dabbagh and Kitsantas (2012) showed that learning in social media support students' self-regulated learning in higher education contexts (see also Mason, 2006; Valtonen et al., 2011) and could thus support their study success as well.

The second benefit concerns student networks. These close communities can be easily established, and they enable students to discuss specific courses, themes, student life, or whatever topics the communities were based on or built for. This kind of sharing can be seen not only enhancing students' study success but also their engagement in studies in addition to their mutual social networking and relationships (e.g., Steinfield et al., 2008). At its best, students can learn how to act as self-organizing, proactive, self-reflecting, and self-regulating individuals within a broad network of socio-structural influences (see also Bandura, 2001a, 2001b).

The third viewpoint to the educative use of social media relates to various skills that are required in today's world, often referred as literacies. There are increasing studies about the benefits of using social media not only to enhance learning of the school subject but also to develop interaction skills when it comes to expressing oneself by posting on social media (Chen, 2012). Without the ability to critically reflect on and efficiently express oneself in social media, SNSs are neither likely to benefit the user nor increase his or her social capital.

When it comes to education, the important implication from our study among university students was that teachers could act as bridging individuals, creating possibilities for bonding among students and thus enhance the sense of meaningful studies and have a positive impact (e.g., Cruce, Wolniak, Seifert, \& Pascarella, 2006; Uusiautti \& Määttä, 2013). As the role of a teacher as a mentor has become more and more important and versatile these days, SNSs can provide a useful way for the teachers' bridging role. According to one study (Kunttu \& Huttunen, 2008), only a little over half of university students feel like belonging to some study group. About one third of them do not feel like belonging to any group. In Lähteenoja's (2010) research, more than half of new university students had 
never discussed scientific questions or their studies, difficulties, or future plans with teachers. Indeed, Kezar and Kinzie (2006) emphasize that focusing on the early years of study and respect for various learning styles and methods are keys to successful and meaningful study paths (see also Kuh, Cruce, Shoup, Kinzie, \& Gonyes, 2008). Here, we see the possibilities of SNSs in education as the place for encounters, information sharing, and distribution and as a way of creating social relationships and increasing students' social capital - as one part of the modern university students' study success.

\section{Resources and positive attitudes}

Perhaps one promising solution to enhance the smoothness of university studies is the strengthening positive thinking and emotions that improve study motivation and attitudes (Beard, Humberstone, \& Clayton, 2014; Rowe, Fitness, Wood, 2015). The difference between positive and negative study attitudes has been show in studies (Segal, Tucker, \& Coolidge, 2009), and luckily, positivity can be learned and practiced consciously (Williams, Childers, \& Kemp, 2013).

Although obstacles and hindrances of fluent study processes have been studied and discovered widely (Salanova, Schaufeli, Martínez, \& Bresó, 2010), new positive psychological viewpoints have given a new direction to view university study processes. Instead of or as a counterbalance to students' difficulties, positive psychology emphasizes students' strengths and their role in fluent, meaningful studies (Van Niekerk, Mostert, \& de Beer, 2016). Furthermore, success in studies boosts engagement and efficiency (Mesurado, Richaud, \& Mateo, 2015) and prevents burnout (Stoeber, Childs, Hayward, \& Feast, 2011).

One important factor that increases meaningfulness in studies is social interaction and learning together with others. The importance of learning with peers and all the interactional elements it includes cannot be overemphasized from the perspective of successful university studies. Young adults who start university studies often in a place far away from their childhood homes break away from their families and prepare themselves for life vocationally, academically, and socially' (Rokach, 2000, p. 629). University studies represents a phase of life when loneliness can step into a young adult's life (e.g., Pressman et al., 2005) if she or he is not able to create peer relationships and participate actively in shared activities. Meaningful student involvement can be enhanced through the learning environment, classroom management and study climate, and extracurricular activities in the campus life (Fletcher, 2005; Pintrich, 1999), which can improve students' engagement with their studies and their feeling of belonging (Kuh et al., 2008; see also Vaarala et al., 2013). As students mentioned in our studies in this part (see also Chapter 3.2), peer relationships enhance their coping with studies and pressures in many ways. They even long for opportunities to interact with peer students, and these are matters that should be given sufficient attention in universities. But not only are peer relationships important for student well-being and study success; the modern world also necessitates more and more sophisticated teamwork skills and abilities. University education should provide opportunities to practice teamwork through group tasks and even group exams. 
When participating in these forms of collaboration, students get the chance to practice work skills that they will need when entering the labor market after their graduation. It is important to realize that no one succeeds alone, and no one is the only ingredient of one's success. As future employees, students should be equipped with these necessary social skills of helping, encouraging, and working together with others (see also Crebert, Bates, Bell, Patrick, \& Cragnolini, 2007).

In addition to peer relationships, relationships with university personnel are crucial. Leskisenoja's (2016) recent study showed that positive relationship, especially with teachers, enhances contentment and well-being at school. The relevance of this kind of a caring teacher-student relationship does not lose its importance at higher levels of education either, which is one of the main themes we discuss in the next part of this book.

To summarize, university teaching and education should, first and foremost, aim at flourishing students (Ouweneel, Le Blanc, \& Schaufeli, 2011). Students enter universities with high hopes and expectations (Rosenstreich, Feldman, Davidson, Maza, \& Margalit, 2015), and their dreams can be fulfilled if they are given opportunities to succeed in their studies. It is important to understand that this flourishing reflects on their vitality (Jones, You, \& Furlong, 2013) and well-being (Howell, 2009), and it is greatly dependent on their resources (Xuereb, 2015). It is worth remembering that student well-being means the well-being of the university and even the whole society. Part 3, therefore, focuses on the ways university teaching and supervision of theses can enhance students' study success.

\section{References}

Äärelä, T., Määttä, K., \& Uusiautti, S. (2016). Caring teachers' ten dos. 'For the teacher, they might be just small things, but for the student they mean the world'. International Forum of Teaching and Studies, 12(1), 10-20.

Aoun, C., Vatanasakdakul, S., \& Ang, K. (2016, March 22). Feedback for thought: Examining the influence of feedback constituents on learning experience. Studies in Higher Education [Online]. doi:10.1080/03075079.2016.1156665

Atkins, M., \& Brown, G. (1988). Effective teacher in higher education. New York, NY: Routledge.

Baker, E. L., Barton, P. E., Darling-Hammond, L., Haertel, E., Ladd, H. L., Linn, R. L., Ravitch, D., Rothstein, R., Shavelson, R. J., \& Shepard, L. A. (2010). Problems with the use of student test scores to evaluate teachers. EPI Briefing Paper 278, Economic Policy Institute. Retrieved from http://files.eric.ed.gov/fulltext/ ED516803.pdf

Bandura, A. (1997). Self-efficacy: The exercise of control. New York, NY: Freeman.

Bandura, A. (2001a). Social cognitive theory: An agentic perspective. Annual Review of Psychology, 52, 1-26.

Bandura, A. (2001b). Social cognitive theory of mass communication. Mediapsychology, 3, 265-299.

Beard, C., Humberstone, B., \& Clayton, B. (2014). Positive emotions: Passionate scholarship and student transformation. Teaching in Higher Education, 19(6), 630643. doi:10.1080/13562517.2014.901950 
Beenstock, M., \& Feldman, D. (2016, March 22). Decomposing university grades: A longitudinal study of students and their instructors. Studies in Higher Education [Online]. doi:10.1080/03075079.2016.1157858

Berscheid, E. (2006). Ihmisen suurin vahvuus: Toiset ihmiset [A human being's greatest strength: Other people]. In L. G. Aspinwall \& U. M. Staudinger (Eds.), Ihmisen vahvuuksien psykologia [A psychology of human strengths] (pp. 47-56). Helsinki: Edita.

Billing, T. K., Bhagat, R. S., Babakus, E., Krishnan, B., Ford, D. L., Srivastava, B. N., Rajadhyaksha, U., Shin, M., Kuo, B., Kwantes, C., Setiadi, B., \& Nasurdin, A. M. (2014). Work - family conflict and organisationally valued outcomes: The moderating role of decision latitude in five national contexts. Applied Psychology: An International Review, 63, 62-95. doi:10.1111/j.1464-0597.2012.00526.x

Bolker, J. (1998). Writing your dissertation on fifteen minutes a day: A guide for starting, revising and finishing your doctoral thesis. New York, NY: Henry Holt.

Boud, D., \& Molloy, E. (2013). Rethinking models of feedback for learning: The challenge of design. Assessment \& Evaluation in Higher Education, 38(6), 698712. doi:10.1080/02602938.2012.691462

Bourdieu, P. (1984). Distinction: A social critique of the judgement of taste. Cambridge, MA: Harvard University Press.

Bourdieu, P. (1996). The forms of capital. In J. G. Richardson (Ed.), Handbook of theory and research for the sociology of education (pp. 241-258). New York, NY: Greenwood Press.

boyd, d. m., \& Ellison, N. B. (2007). Social network sites: Definition, history, and scholarship. Journal of Computer-Mediated Communication, 13, 210-230. doi:10.1111/j.1083-6101.2007.00393.x

Brunello, G., \& Winter-Ebmer, R. (2003). Why do students expect to stay longer in college? Evidence from Europe. Economics Letters, 80(2), 247-253. doi:10.1016/ S0165-1765(03)00086-7

Budría, S., \& Moro-Egido, A. (2014). Overqualification, skill mismatches and wages in private sector employment in Europe. Technological and Economic Development of Economy, 20(3), 457-483.

Busato, V. V., Prins, F. J., Elshout, J. J., \& Hamaker, C. (2000). Intellectual ability, learning style, personality, achievement motivation and academic success of psychology students in higher education. Personality and Individual Differences, 29(6), 1057-1068. doi; 10.1016/S0191-8869(99)00253-6

Caers, R., De Feyter, T., De Couck, M., Stough, T., Vigna, C., \& Du Bois, C. (2013). Facebook: A literature review. New Media \& Society, 5(6), 982-1002 doi: $10.1177 / 1461444813488061$.

Cano, F. (2005). Epistemological beliefs and approaches to learning: Their change through secondary school and their influence on academic performance. British Journal of Educational Psychology, 75(2), 203-221. doi:10.1348/000709904X22683.

Caprara, G. V., \& Cervone, D. (2006). Persoonallisuus toimivana, itsesäätelevänä järjestelmänä [Personality as functional, self-regulatie system]. In L. G. Aspinwall \& U. M. Staudinger (Eds.), Ihmisen vahvuuksien psykologia [A psychology of human strengths] (pp. 69-82). Helsinki: Edita.

Carless, D., Salter, D., Yang, M., \& Lam, J. (2011). Developing sustainable feedback practices. Studies in Higher Education, 36(4), 395-407. doi:10.1080/03075071003642449

Carruthers, C., \& Hood, C. D. (2005, October). The power of positive psychology. Parks \& Recreation, 30-37. 
Carver, C. S., \& Scheier, M. F. (2005). Engagement, disengagement, coping, and catastrophe. In A. J. Elliot \& C. S. Dweck (Eds.), Handbook of competence and motivation (pp. 527-547). New York, NY: Guilford Press.

Chafouleas, S. M., \& Bray, M. A. (2004). Introducing positive psychology: Finding a place within school psychology. Psychology in the Schools, 41(1), 1-6.

Chambaz, J., Biaudet, P., \& Collonge, S. (2006). Developing the doctorate. In E. Froment, J. Kohler, L. Purse, \& L. Wilson (Eds.), Bologna handbook (pp. 1-18). Berlin: Raabe Academic Publishers.

Chamorro-Premuzic, T., \& Furnham, A. (2003). Personality predicts academic performance: Evidence from two longitudinal university samples. Journal of Research in Personality, 37(4), 319-338. doi:10.1016/S0092-6566(02)00578-0

Chappel, C., \& Johnston, R. (2003). Changing work: Changing roles for vocational education and training teachers and trainers. Leabrook: National Centre for Vocational Education Research.

Chen, H-I. (2012). Social networking, socialization, and second language writers: The development of new identities and literacies. Ph.D, diss., University of Arizona.

Chesser, S. (2015). Intersection of family, work and leisure during academic training. Annals of Leisure Research, 18(3), 308-322.

Conard, M. A. (2006). Aptitude is not enough: How personality and behavior predict academic performance. Journal of Research in Personality, 40(3), 339-346. doi:10.1016/j.jrp.2004.10.003

Corcoran, S. P. (2010). Can teachers be evaluated by their students' test scores? Should they be? The use of value-added measures of teacher effectiveness in policy and practice. Education Policy for Action Series. Annenberg Institute for School Reform at Brown University (NJl). Retrieved from http://eric.ed.gov/?id=ED522163

Cortes, K., Mostert, K., \& Els, C. (2014). Examining significant predictors of students' intention to drop out. Journal of Psychology in Africa, 24(2), 179-185. doi: $10.1080 / 14330237.2014 .903070$

Costley, C., \& Armsby, P. (2007). Research influences on a professional doctorate. Research in Post-Compulsory Education, 12(3), 343-355.

Costley, C., \& Stephenson, J. (2009). Building doctorates around individual candidates' professional experience. In D. Boud \& A. Lee (Eds.), Changing practices of doctoral education (pp. 171-186). London and New York: Routledge.

Cowan, B. W. (2011). Forward-thinking teens: The effects of college costs on adolescent risky behavior. Economics of Education Review, 30(5), 813-825.

Crebert, G., Bates, M., Bell, B., Patrick, C. J., \& Cragnolini, V. (2007). Developing generic skills at university, during work placement and in employment: Graduates' perceptions. Higher Education Research \& Development, 23(2), 147-165. doi:10.1080/0729436042000206636

Cruce, T., Wolniak, G. C., Seifert, T. A., \& Pascarella, E. T. (2006). Impacts of good practices on cognitive development, learning orientations, and graduate degree plans during the first year of college. Journal of College Student Development, 47, 365-383. doi:10.1353/csd.2006.0042

Cryer, R. (2003). The research student's guide to success. Maidenhead: Open University Press.

Csikszentmihalyi, M. (2000). Beyond boredom and anxiety: Experiencing flow in work and play. San Francisco, CA: Jossey-Bass Publishers.

Csikszentmihalyi, M. (2008). Flow: The psychology of optimal experience. New York, NY: Harper Perennial/Modern Classics. 
Csikszentmihalyi, M., Abuhamdeh, S., \& Nakamura, J. (2005). Flow. In A. J. Elliot \& C. S. Dweck (Eds.), Handbook of competence and motivation (pp. 598-608). New York, NY: The Guilford Press.

Ćukušić, M., Garača, Ž., \& Jadrić, M. (2014). Online self-assessment and students' success in higher education institutions. Computers \& Education, 72, 100-109. doi:10.1016/j.compedu.2013.10.018

Cullen, D., Pearson, M., Saha, L. J., \& Spear, R. H. (1994). Establishing effective Phd supervision. Canberra: Australian Government Publishing Service.

Cullen, K. L., Gentry, W. A., \& Yammarino, F. J. (2015). Biased self-perception tendencies: Self-enhancement/self-diminishment and leader derailment in individualistic and collectivistic cultures. Applied Psychology: An International Review, 64(1), 161-207. doi:10.1111/apps.12026

Dabbagh, N., \& Kitsantas, A. (2012). Personal learning environments, social media, and selfregulated learning: A natural formula for connecting formal and informal learning. The Internet and Higher Education, 15, 3-8. doi:10.1016/j. iheduc.2011.06.002

Delamont, S., Atkinson, P., \& Parry, O. (2000). Supervising the PhD: A guide to success. Baltimore, MD: Open University Press.

DePillis, E., \& Johnson, G. (2015). First, do no harm: Effective, ineffective and counterproductive teaching methods. Journal of Higher Education Theory and Practice, 15(1), 58 .

Dill, D., Mitra, S., Jensen, H., Lehtinen, E., Mäkelä, T., Parpala, A., Pohjola, H., Ritter, M., \& Saari, S. (2006). PhD training and the knowledge based society: An evaluation of doctoral education in Finland. International Postgraduate Students Mirror 2006. Helsinki: Finnish Higher Education Evaluation Council.

Dockery, A. M., Seymour, R., \& Koshy, P. (2016). Promoting low socio-economic participation in higher education: A comparison of area-based and individual measures. Studies in Higher Education, 41(9), 1692-1714. doi:10.1080/03075079.2 015.1020777

Dolton, P. J., \& Silles, M. A. (2008). The effects of over-education on earnings in the graduate labour market. Economics of Education Review, 27(2), 125-139. doi:10.1 080/03075079.2015.1020777

Doncaster, K., \& Lester, S. (2002). Capability and its development: Experiences from a work-based doctorate. Studies in Higher Education, 27(1), 91-101.

Dresel, M., Schmitz, B., Schober, B., Spiel, C., Ziegler, A., Engelschalk, T., \& Steuer, G. (2015). Competencies for successful self-regulated learning in higher education: Structural model and indications drawn from expert interviews. Studies in Higher Education, 40(3), 454-470. doi:10.1080/03075079.2015.1004236.

Duff, A., Boyle, E., Dunleavy, K., \& Ferguson, J. (2004). The relationship between personality, approach to learning and academic performance. Personality and Individual Differences, 36(8), 1907-1920. doi:10.106/j.paid.2003.08.020.

Eide, E. R., \& Showalter, M. H. (2011). Estimating the relation between health and education: What do we know and what do we need to know? Economics of Education Review, 30(5), 778-791. doi:10.1016/j.econedurev.2011.03.009

Elias, M. (2004). The connection between social-emotional learning and learning disabilities: Implications for intervention. Disability Quarterly, 27(1), 53-64.

Ellison, N. B., Steinfield, C., \& Lampe, C. (2007). The benefits of Facebook 'friends': Social capital and college students' use of online social network sites. Journal of Computer-Mediated Communication, 12, 1143-1168. doi:10.1111/j.1083-6101.2007.00367.x 
Eraut, M. (2004). Informal learning in the workplace. Studies in Continuing Education, 26(2), 247-273.

Fallows, S., \& Steven, C. (2000). Building employability skills into the higher education curriculum: A university-wide initiative. Education + Training, 42(2), 75-83. doi:10.1108/00400910010331620

FitzSimmons, R. (2014). On the importance of collaborative peer learning as a collective learning experience in Finnish higher education classrooms. Critical Education, 5(16), 1-17.

Fletcher, A. (2005). Meaningful student involvement: Guide to students as partners in school change (2nd ed.). Olympia, WA: The FreeChild Project. Retrieved from www.soundout.org/MSIGuide.pdf

Furnham, A., Chamorro-Premuzic, T., \& McDougall, F. (2002). Personality, cognitive ability, and beliefs about intelligence as predictors of academic performance. Learning and Individual Differences, 14(1), 47-64. doi:10.1016/j.lindif.2003.08.002

Galbraith, C. S., \& Merrill, G. B. (2015). Academic performance and burnout: An efficient frontier analysis of resource use efficiency among employed university students. Journal of Further and Higher Education, 39(2), 255-277. doi:10.1080(03 09877X.2013.858673

Gardner, H., Csikszentmihalyi, M., \& Damon, W. (2001). Good work: When excellence and ethics meet. New York, NY: Basic Books.

Gardner, W. L., Avolio, B. J., Luthans, F., May, D. R., \& Walumbwa, F. (2005). 'Can you see the real me?' A self-based model of authentic leader and follower development. The Leadership Quarterly, 16, 343-372.

Ghorpade, J., Lackritz, J., \& Singh, G. (2006). Views of employee participation, higher order needs, altruism, pride in craftsmanship, and collectivism: Implications for organizational practice and public policy. Journal of Applied Social Psychology, 36, 2474-2491. doi:10.1111/j.0021-9029.2006.00113.x

Gillham, J., \& Reivich, K. (2004). Cultivating optimism in childhood and adolescence. The ANNALS of the American Academy of Political and Social Science, 591, $146-163$.

Gilpin, J. M. (2008). Teaching happiness: The role of positive psychology in the classroom. Pell Scholars and Senior Theses, 12, 1-23.

Golde, C. M. (2000). 'Should I stay or should I go?': Student descriptions of the doctoral attrition process. Review of Higher Education, 23(2), 199-227.

Golde, C. M., \& Walker, G. E. (2006). Envisioning the future of doctoral education: Preparing stewards of the discipline. San Francisco, CA: Jossey-Bass.

González, M. D. L. O., Jareño, F., \& López, R. (2015). Impact of students’ behavior on continuous assessment in Higher Education. Innovation: The European Journal of Social Science Research, 28(4), 498-507.

Green, H., \& Powell, S. (2005). Doctoral study in contemporary higher education. Buckingham: Open University Press.

Green, J., Liem, G. A., Martin, A. J., Colmar, S., Marsh, H. W., \& McInerney, D. (2012). Academic motivation, self-concept, engagement and performance in high school: Key processes from a longitudinal perspective. Journal of Adolescence, 35(5), 1111-1122.

Gross, J. J., \& John, O. P. (2003). Individual differences in two emotion regulation processes: Implications for affect, relationships, and well-being. Journal of Personality and Social Psychology, 85(2), 348-362. doi:10.1037/0022-3514.85.2.348

Hakanen, J., Perhoniemi, R., \& Toppinen-Tanner, S. (2008). Positive gain spirals at work: From job resources to work engagement, personal initiative and 
work-unit innovativeness. Journal of Vocational Behavior, 73, 78-91. doi:10.1016/j. jvb.2008.01.003

Hamer, J., Purchase, H., Luxton-Reilly, A., \& Denny, P. (2015). A comparison of peer and tutor feedback. Assessment \& Evaluation in Higher Education, 40(1), 151-164. doi:10.1080/02602938.2014.893418

Hansen, B., \& Lang, M. (2011). Back to school blues: Seasonality of youth suicide and the academic calendar. Economics of Education Review, 30(5), 850-861.

Hartog, J. (2000). Over-education and earnings: Where are we, where should we go? Economics of Education Review, 19(2), 131-147. doi:10.1016/ S0272-7757(99)00050-3

Haythornthwaite, C. (2005). Social networks and internet connectivity effects. Information, Communication \& Society. 8(2), 125-147. doi: $10.1080 / 13691180500146185$.

Hébert, T. P. (1993). Reflections at graduation: The long-term impact of elementary school experiences in creative productivity. Roeper Review, 16(1), 22-28.

Helmke, A., \& Schrader, F. W. (1988). Successful student practice during seatwork: Efficient management and active supervision not enough. The Journal of Educational Research, 82(2), 70-76.

Himanen, P. (2007). Suomalainen unelma: Innovaatioraportti [The Finnish dream: The innovation report]. Helsinki: Teknologiateollisuuden 100-vuotissäätiö.

Hogg, M. A., Abrams, D., Otten, S., \& Hinkle, S. (2004). The social identity perspective intergroup relations, self-conception, and small groups. Small Group Research, 35(3), 246-276. doi:10.1177/1046496404263424

Howell,A.J.(2009). Flourishing:Achievement-related correlatesofstudents'well-being. The Journal of Positive Psychology, 4(1), 1-13. doi:10.1080/17439760802043459

Huang, X., \& Viert, E. V. d. (2004). Job level and national culture as joint roots of job satisfaction. Applied Psychology: An International Review, 53, 329-348. doi:10.1111/j.1464-0597.2004.00174.x

Isen, A. M., \& Reeve, J. (2006). The influence of positive affect on intrinsic and extrinsic motivation: Facilitating enjoyment of play, responsible work behavior, and selfcontrol. Motivation and Emotion, 29, 297-325. doi:10.1007/s11031-006-9019-8

Johnson, H. (2001). The PhD Student as an Adult Learner: Using reflective practice to find and speak in her own voice. Reflective Practice, 2(1), 53-63.

Jones, C. N., You, S., \& Furlong, M. J. (2013). A preliminary examination of covitality as integrated well-being in college students. Social Indicators Research, 111(2), 511-526.

Judge, T. A., Locke, E. A., \& Durham, C. C. (1997). The dispositional causes of job satisfaction. Research in Organizational Behavior, 19, 151-188.

Kahneman, D., \& Krueger, A. B. (2006). Developments in the measurement of subjective wellbeing. Journal of Economic Perspectives, 20, 3-24.

Kanfer, R., \& Ackerman, P. L. (2005). Work competence: A person-oriented perspective. In A. J. Elliot \& C. S. Dweck (Eds.), Handbook of competence and motivation (pp. 336-353). New York and London: The Guilford Press.

Kavanaugh, A., Reese, D., Carroll, J., \& Rosson, M. (2005). Weak ties in networked communities. Information Society, 21, 119-131.

Keup, J., \& Barefoot, B. (2005). Learning how to be a successful student: Exploring the impact of first-year seminars on student outcomes. Journal of the First-Year Experience \& Students in Transition, 17(1), 11-47. 
Kezar, A. J., \& Kinzie, J. L. (2006). Examining the ways institutions create student engagement: The role of mission. Journal of College Student Development, 47, 149172. doi: $10.1353 / \mathrm{csd} .2006 .0018$

Konttinen, R. (1995). Arvostelusta näyttöön: Koulutuksen arvioinnin kehityspiirteitä Suomessa [From evaluation to proof of expertise: The developmental features of educational evaluation in Finland]. Kasvatus, 26(1), 6-14.

Kuh, G. D., Cruce, T. M., Shoup, R., Kinzie, J., \& Gonyes, R. M. (2008). Unmasking the effects of student engagement on first-year college grades and persistence. The Journal of Higher Education, 79, 540-563. doi:10.1353/jhe.0.0019

Kunttu, K., \& Huttunen, T. (2008). Korkeakouluopiskelijoiden terveystutkimus 2008 [Survey on higher education students' health 2008]. Helsinki: YTHS.

Lähteenoja, S. (2010). Uusien opiskelijoiden integroituminen yliopistoon - Sosiaalipsykologinen näkökulma [New students' integration to the university - a social-psychological perspective]. Helsinki: University of Helsinki. Retrieved from http:// urn.fi/URN:ISBN:978-952-10-6086-1

Lee, M. R., Yen, D. C., \& Hsiao, C. Y. (2014). Understanding the perceived community value of Facebook users. Computers in Human Behavior, 35, 350-358. doi:10.1016/j.chb.2014.03.018

Leonard, D. (2001). A woman's guide to doctoral studies. Buckingham: Open University Press.

Lerner, R. M., Lerner, J. V., von Eye, A., Bowers, E. P., \& Lewin-Bizan, S. (2011). Individual and contextual bases of thriving in adolescence: A view of the issues. Journal of Adolescence, 34, 1107-1114. doi:10.1016/j.adolescence.2011.08.001

Leskisenoja, E. (2016). Vuosi koulua-puosi iloa. PERMA-teoriaan pohjautuvat luokkakäytänteet kouluilon edistäjinä [Year of school, year of joy - PERMA-based classroom practices enhancing perceived joy at school]. Rovaniemi: Lapland University Press.

Liden, R. C., Wayne, S. J., \& Sparrowe, R. T. (2000). An examination of the mediating role of psychological empowerment on the relations between the job, interpersonal relationships, and work outcomes. Journal of Applied Psychology, 85(3), 407-416.

Locke, E. A., \& Latham, G. P. (1990). Work motivation and satisfaction: Light at the end of the tunnel. Psychological Science, 1(4), 240-246.

Lowe, J., \& Gayle, V. (2007). Exploring the work/life/study balance: The experience of higher education students in a Scottish further education college. Journal of Further and Higher Education, 31(3), 225-238. doi:10.1080/03098770701424942.

Ludemann, P. M., \& McMakin, D. (2014). Perceived Helpfulness of Peer Editing Activities: First-year students' views and writing performance outcomes. Psychology Learning \& Teaching, 13(2), 129-136. doi:10.2304/plat.2014.13.2.129

Lundgren, U. (2002). Voidaanko koulujärjestelmää arvioida kansallisella tasolla? [Is it possible to evaluate education system at the national level?] In R. Honkonen (Ed.), Koulutuksen lumo: Retoriikka, politiikka ja arviointi [The fascination of education: Rhetorics, politics, and evaluation] (pp. 193-207). Tampere: Tampere University Press.

Lynch, K. (2013). Dimensions of performance. In M. Larice \& E. Macdonald (Eds.), The urban design reader (pp. 229-234). New York, NY: Routledge.

Määttä, K. (2011). The dissertation process described by doctoral students in Finland. E-International Journal of Educational Research, 2(1), 66-80. 
Määttä, K. (2012). The pedagogy of supervising doctoral theses. In K. Määttä (Ed.), Obsessed with doctoral theses (pp. 143-160). Rotterdam: Sense Publishers.

Määttä, K., \& Uusiautti, S. (2012). How to enhance the smoothness of university students' study paths. International Journal of Research Studies in Education, 1(1), 47-60. doi:105861/ijrse.2012.vlil.16.

Määttä, K., \& Uusiautti, S. (2014). Love-based leadership at school as a way to wellbeing in pupils - theoretical and practical considerations. International Journal of Education, 6(3), 1-12. doi:10.5296/ije.v6i3.6042

Määttä, K., \& Uusiautti, S. (2016). What are successful fast-graduating Masters made of? International Journal of Arts and Sciences, 9(3), 1-12.

Määttä, K., Uusiautti, S., \& Määttä, M. (2016). A story of an ideal study process. In S. Uusiautti \& K. Määttä (Eds.), The basics of caring research (pp. 91-102). Rotterdam: Sense Publishers.

Maltfroy, J., \& Yates, L. (2003). Knowledge in action: Doctoral programmes forging new identities. Journal of Higher Education Policy and Management, 25(2), 119-129.

Mason, R. (2006). Learning technologies for adult continuing education. Studies in Continuing Education, 28, 121-133. doi:10.1080/01580370600751039

McKenzie, K., \& Schweitzer, R. (2001). Who succeeds at university? Factors predicting academic performance in first year Australian university students. Higher Education Research \& Development, 20(1), 21-33. doi:10.1080/079243601 20043621

McWilliam, E. L., Dawson, S. P., \& Tan, J. P-L. (2008). From vaporousness to visibility: What might evidence of creative capacity building actually look like? The UNESCO Observatory, 1(3). Retrieved from http://eprints.qut.edu.au/17093/1/ c17093.pdf

McWilliam, E., Lawson, A., Evans, T., \& Taylor, P. G. (2005). Silly, soft and otherwise suspect: Doctoral education as a risky business. Australian Journal of Education, 49(2), 214-227.

Mesurado, B., Richaud, M. C., \& Mateo, N. J. (2015). Engagement, flow, self-efficacy, and eustress of university students: A cross-national comparison between the Philippines and Argentina. The Journal of Psychology, 150(3), 281-99. doi:10.1080 $/ 00223980.2015 .1024595$

Mills, J. S., \& Blankstein, K. R. (2000). Perfectionism, intrinsic vs extrinsic motivation, and motivated strategies for learning: A multidimensional analysis of university students. Personality and Individual Differences, 29(6), 1191-1204. doi:10.1016/ S0191-8869(00)00003-9.

Mitchell, T. R. (1997). Matching motivational strategies with organizational contexts. Research in Organizational Behavior, 19, 57-149.

Murray, L., \& Lawrence, B. (2008). The basis of critique of practitioner-based enquiry. In L. Murray \& B. Lawrence (Eds.), Practitioner-based enquiry: Principles for postgraduate research (pp. 18-41). London: Falmer Press.

Nadkarni, A., \& Hofmann, S. G. (2012). Why do people use Facebook? Personality and Individual Differences, 52, 243-249. doi:10.1016/j.paid.2011.11.007

Nicol, D. J., \& Macfarlane-Dick, D. (2006). Formative assessment and self-regulated learning: A model and seven principles of good feedback practice. Studies in Higher Education, 31(2), 199-218. doi:10.1080/03075070600572090.

Niemi, H., \& Multisilta, J. (Eds.). (2014). Rajaton luokkahuone [Limitless classroom]. Jyväskylä: PS-Kustannus. 
Oades, L. G., Robinson, P., Green, S., \& Spence, G. B. (2011). Towards a positive university. The Journal of Positive Psychology: Dedicated to Furthering Research and Promoting Good Practice, 6(6), 432-439. doi:10.1080/17439760.2011.634828

Oldmeadow, J. A., Quinn, S., \& Kowert, R. (2013). Attachment style, social skills, and Facebook use amongst adults. Computers in Human Behavior, 29(3), 1142-1149.

Olwage, D., \& Mostert, K. (2014). Predictors of student burnout and engagement among university students. Journal of Psychology in Africa, 24(4), 342-350. doi:10 .1080/14330237.2014.978087

Ouweneel, E., Le Blanc, P. M., \& Schaufeli, W. B. (2011). Flourishing students: A longitudinal study on positive emotions, personal resources, and study engagement. The Journal of Positive Psychology, 6(2), 142-153. doi:10.1080/17439760. 2011.558847

Peura, A. (2008). Tohtoriksi tulemisen tarina [The story of dissertation process]. The research reports of the Department of Education 219. Helsinki, Finland: University of Helsinki.

Phan, H. P. (2008). Predicting change in epistemological beliefs, reflective thinking and learning styles: A longitudinal study. British Journal of Educational Psychology, 78(1), 75-93. doi:10.1348/000709907X204354

Philips, M., \& Pugh, D. (2005). How to get a PhD: A handbook for students and their supervisors. Maidenhead: Open University Press.

Pintrich, P. R. (1999). The role of motivation in promoting and sustaining self-regulated learning. International Journal of Educational Research, 31(6), 459-470. doi:10.1016/S0883-0355(99)00015-4.

Pintrich, P. R. (2003). A Motivational science perspective on the role of student motivation in learning and teaching contexts. Journal of Educational Psychology, 95(4), 667-696.

Pintrich, P. R., \& Garcia, T. (1994). Self-regulated learning in college students: Knowledge, strategies, and motivation. In P. R. Pintrich, D. R. Brown, \& C. E. Weinstein (Eds.), Student motivation, cognition, and learning (pp. 113-133). Hillside, NJ: Lawrence Erlbaum Associates.

Pressman, S. D., Cohen, S., Miller, G. E., Barkin, A., Rabin, B. S., \& Treanor, J. J. (2005). Loneliness, social network size, and immune response to influenza vaccination in college freshmen. Health Psychology, 24(3), 297-306.

Przybylsk, A. K., \& Weinstein, N. (2012). Can you connect with me now? How the presence of mobile communication technology influences face-to-face conversation quality. Journal of Social and Personal Relationships, 30, 237-246.

Pyhältö, K., Soini, T., \& Pietarinen, J. (2010). Pupils' pedagogical well-being in comprehensive school - significant positive and negative school experiences of Finnish ninth graders. European Journal of Psychology of Education, 25, 207-221. doi:10.1007/s10212-010-0013-x

Rae, I. D. (2002). False start for the PhD in Australia. Historical Records of Australian Science, 14, 129-141.

Rantala, T., \& Määttä, K. (2010). Ten thesis of the joy of learning at primary schools. Early Child Development and Care, 182(1), 87-105.

Rauscher, E., \& Elliott III, W. (2014). The effect of wealth inequality on higher education outcomes: A critical review. Sociology Mind, 4(4), 282.

Reed, R. J., \& Hurd, B. (2014). A value beyond money? Assessing the impact of equity scholarships: From access to success. Studies in Higher Education, 41(7), 1236-1250. doi:10.1080/03075079.2014.968541 
Reiss, S. (2012). Intrinsic and extrinsic motivation. Teaching of Psychology, 39(2), 152-156. doi:10.1177/0098628312437704.

Rodger, S., \& Tremblay, P. F. (2003). The effects of a peer mentoring program on academic success among first year university students. The Canadian Journal of Higher Education, 33(3), 1-18.

Rohn, U. (2014). Social networking sites across cultures and countries: Proximity and network effects. Qualitative Research Reports in Communication, 14, 28-34. doi:1 $0.1080 / 17459435.2013 .835339$

Rokach, A. (2000). Loneliness and the life cycle. Psychological Reports, 86(2), 629-642.

Rosenstreich, E., Feldman, D. B., Davidson, O. B., Maza, E., \& Margalit, M. (2015). Hope, optimism and loneliness among first-year college students with learning disabilities: A brief longitudinal study. European Journal of Special Needs Education, $30(3), 338-350$.

Rothstein, J. (2009). Student sorting and bias in value-added estimation: Selection on observables and unobservables. Education, 4(4), 537-571. doi:10.1162/ edfp.2009.4.4.537

Rowe, A. D., Fitness, J., \& Wood, L. N. (2015). University student and lecturer perceptions of positive emotions in learning. International Journal of Qualitative Studies in Education, 28(1), 1-20. doi:10.1080/09518398.2013.847506

Ryan, F. J., Soven, M., Smither, J., Sullivan, W. M., \& Vanbuskirk, W. R. (1999). Appreciative inquiry: Using personal narratives for initiating school reform. Clearing House, 72(3), 164-167.

Ryan, R. M., \& Deci, E. L. (2000). Self-determination theory and the facilitation of intrinsic motivation, social development, and well-being. American Psychologist, 55(1), 68-78. doi:10.1037/0003-066X.55.1.68.

Rychen, D., \& Salganik, L. (2003). A holistic model of competence. In D. Rychen \& L. Salganik (Eds.), Key competencies for a successful life and well-functioning society (pp. 41-62). Cambridge: Hogrefe and Huber.

Salanova, M., Schaufeli, W., Martínez, I., \& Bresó, E. (2010). How obstacles and facilitators predict academic performance: The mediating role of study burnout and engagement. Anxiety, Stress \& Coping, 23(1), 53-70. doi:10.1080/10615800802609965

Salmela, M., \& Määttä, K. (2015). Even the best have difficulties - a study of Finnish straight-A graduates' resource-oriented solutions. Gifted Child Quarterly, 59(2), 124-135. doi:10.1177/0016986214568720

Salmela, M., \& Uusiautti, S. (2013). Finnish straight-A graduates' perceptions of the smoothness of their study paths. Journal of Studies in Education, 3(4), 21-41. doi:10.5296/jse.v3i4.4270

Salmela, M., \& Uusiautti, S. (2015). A positive psychological viewpoint for success at school - Ten characteristic strengths of the Finnish high-achieving students. High Ability Studies, 26(1), 117-137. doi:10.1080/13598139.2015.1019607

Sánchez-Sánchez, N., \& McGuinness, S. (2015). Decomposing the impacts of overeducation and overskilling on earnings and job satisfaction: An analysis using REFLEX data. Education Economics, 23(4), 419-432.

Saslow, L. R., Muise, A., Impett, E. A., \& Dubin, M. (2012). Can you see how happy we are? Facebook images and relationship satisfaction. Social Psychological and Personality Science, 4, 411-418. doi:10.1177/1948550612460059 
Schaufeli, W. B., Salanova, M., Gonzalez-Roma, V., \& Bakker, A. B. (2002). The measurement of engagement and burnout: A two sample confirmatory factor analytic approach. Journal of Happiness Studies, 3, 71-92.

Schellenberg, B. J., \& Bailis, D. S. (2015). Predicting longitudinal trajectories of academic passion in first-year university students. Learning and Individual Differences, 40, 149-155.

Scherer, K. (1997). College life on-line: Healthy and unhealthy internet use. Journal of College Student Development, 38, 655-665.

Schunk, D. H., \& Pajares, F. (2005). Competence perceptions and academic functioning. In A. J. Elliot \& C. S. Dweck (Eds.), Handbook of competence and motivation (pp. 85-104). New York, NY: The Guildford Press.

Seder, J. P., \& Oishi, S. (2012). Intensity of smiling in Facebook photos predicts future life satisfaction. Social Psychological and Personality Science, 3, 407-413. doi:10.1177/1948550611424968

Segal, D. L., Tucker, H. C., \& Coolidge, F. L. (2009). A comparison of positive versus negative emotional expression in a written disclosure study among distressed students. Journal of Aggression, Maltreatment \& Trauma, 18(4), 367-381. doi:10.1080/10926770902901345

Seligman, M. E. P. (2002). Authentic happiness: Using the new positive psychology to realize your potential for lasting fulfillment. New York, NY: Free Press.

Seligman, M. E. P. (2011). Flourish: A visionary new understanding of happiness and well-being. New York, NY: Free Press.

Selwyn, N. (2009). Faceworking: Exploring students' education related use of Facebook. Learning, Media and Technology, 34, 157-174.

Shahidi, M., \& Sobhani, A. (2015). Psycho-educational problems in large academic classes: Learning motivation within psycho-educational atmosphere. Academic Research International, 6(1), 322.

Shulman, L. S. (1987). Knowledge and teaching: Foundations of the new reform. Harvard Educational Review, 57(1), 1-22.

Silius, K., Miilumäki, T., Huhtamäki, J., Tebest, T., Meriläinen, J., \& Pohjolainen, S. (2010). Students' motivations for social media enhanced studying and learning. Knowledge Management \& E-Learning: An International Journal, 2, 51-67.

Simola, H. (2002). From exclusion to self-selection: Examination of behaviour in Finnish primary and comprehensive schooling from the 1960s to the 1990s. History of Education, 31(3), 207-226.

Solomon, P. (2004). Peer support/peer provided services underlying processes, benefits, and critical ingredients. Psychiatric Rehabilitation Journal, 27, 392-401.

Steinfield, C., Ellison, N. B., \& Lampe, C. (2008). Social capital, self-esteem, and use of online social network sites: A longitudinal analysis. Journal of Applied Developmental Psychology, 29, 434-445. doi:10.1016/j.appdev.2008.07.002

Stellmack, M. A., Keenan, N. K., Sandidge, R. R., Sippl, A. L., \& Konheim-Kalkstein, Y. L. (2012). Review, revise, and resubmit: The effects of self-critique, peer review, and instructor feedback on student writing. Teaching of Psychology, 39(4), 235-244. doi:10.1177/0098628312456589

Stoeber, J., Childs, J. H., Hayward, J. A., \& Feast, A. R. (2011). Passion and motivation for studying: Predicting academic engagement and burnout in university students. Educational Psychology, 31(4), 513-528. doi:10.1080/01443410.2011 .570251 
Stoltenberg, C. D. (2005). Enhancing professional competence through developmental approaches to supervision. American Psychologist, 6, 857-864.

Stratton, L. S., O’Toole, D. M., \& Wetzel, J. N. (2008). A multinomial logit model of college stopout and dropout behavior. Economics of Education Review, 27(3), 319-331. doi:10.1016/j.econedurev.2007.04.003

Takahashi, Y., Uchida, C., Miyaki, K., Sakai, M., Shimbo, T., \& Nakayama, T. (2009). Potential benefits and harms of a peer support Social Network Service on the internet for people with depressive tendencies: Qualitative content analysis and social network analysis. Journal of Medical Internet Research, 11, e29. doi:10.2196/ jmir.1142.

Tarvid, A. (2013). Unobserved heterogeneity in overeducation models: Is personality more important than ability? Procedia Economics and Finance, 5, 722-731.

Thompson, C. A., \& Prottas, D. J. (2006). Relationships among organizational family support, job autonomy, perceived control, and employee well-being. Journal of Occupational Health Psychology, 11(1), 100-118. doi:10.1037/1076-8998.10.4.100

Thompson, J. E., Stuart, R., \& Lindsay, P. R. (1997). The competence of top team members: A framework for successful performance. Team Performance Management, 3(2), 57-75. doi:10.1108/13527599710190957

Topping, K. (1998). Peer assessment between students in colleges and universities. Review of EducationalResearch, 68(3),249-276.doi:10.1177/1469787414527391

Tsang, A. H., Jardine, A. K., \& Kolodny, H. (1999). Measuring maintenance performance: A holistic approach. International Journal of Operations \& Production Management, 19(7), 691-715. doi:10.1108/01443579910271674.

Uusiautti, S. (2013). On the positive connection between success and happiness. International Journal of Research Studies in Psychology, 3(1), 1-11. doi:10.5861/ ijrsp.2013.509

Uusiautti, S., \& Määttä, K. (2011). The ability to love - a virtue-based approach. British Journal of Educational Research, 2(1), 1-19.

Uusiautti, S., \& Määttä, K. (2013). Enhancing students' study success through caring leadership. European Scientific Journal, 2(2), 398-407.

Uusiautti, S., \& Määttä, K. (2015). The psychology of becoming a successful worker: Research on the changing nature of achievement at work. New York, NY: Routledge.

Uusiautti, S., \& Määttä, K. (2016). Caring research and its future challenges. In S. Uusiautti \& K. Määttä (Eds.), The basics of caring research (pp. 137-144). Rotterdam: Sense Publishers.

Vaarala, M., Uusiautti, S., \& Määttä, K. (2013). College students' experiences of and coping with loneliness - possibilities of peer support. International Journal of Research Studies in Education, 2(4), 13-28. doi:10.5861/ijrse.2013.510

Valenzuela, S., Park, N., \& Kee, K. F. (2009). Is there social capital in a social network site? Facebook use and college students' life satisfaction, trust, and participation. Journal of Computer-Mediated Communication, 14, 875-901. doi:10.1111/j.1083-6101.2009.01474.x

Valkenburg, P. M., Peter, J., \& Schouten, A. P. (2006). Friend networking sites and their relationship to adolescents' well-being and social self-esteem. CyberPsychology \& Behavior, 9, 584-590.

Valle, A., Cabanach, R. G., Núnez, J. C., González-Pienda, J., Rodríguez, S., \& Piñeiro, I. (2003). Multiple goals, motivation and academic learning. British Journal of Educational Psychology, 73(1), 71-87. doi:10.1348/000709903762869923 
Valtonen, T., Pöntinen, S., Kukkonen, J., Dillon, P., Väisänen, P., \& Hacklin, S. (2011). Confronting the technological pedagogical knowledge of Finnish Net Generation student teachers. Technology, Pedagogy and Education, 20, 3-18. doi:1 $0.1080 / 1475939 X .2010 .534867$

Van Niekerk, G., Mostert, K., \& de Beer, L. T. (2016). Strengths use and deficit improvement: The relationship with engagement and fit with study course amongst first-year students. Journal of Psychology in Africa, 26(1), 43-48.

West, J., \& Turner, W. (2016). Enhancing the assessment experience: Improving student perceptions, engagement and understanding using online video feedback. Innovations in Education and Teaching International, 53(4), 400-410. doi:10.10 80/14703297.2014.1003954

Wierstra, R. F., Kanselaar, G., Van Der Linden, J. L., \& Lodeewijks, H. G. (1999). Learning environment perceptions of European university students. Learning Environments Research, 2(1), 79-98.

Wiliam, D. (2010). What counts as evidence of educational achievement? The role of constructs in the pursuit of equity in assessment. Review of Research in Education, $34,254-283$.

Williams, K. H., Childers, C., \& Kemp, E. (2013). Stimulating and enhancing student learning through positive emotions. Journal of Teaching in Travel \& Tourism, 13(3), 209-227. doi:10.1080/15313220.2013.813320

Winstone, N. E., Nash, R. A., Rowntree, J., \& Menezes, R. (2016). What do students want most from written feedback information? Distinguishing necessities from luxuries using a budgeting methodology. Assessment \& Evaluation in Higher Education, 41(8), 1237-1253. doi:10.1080/02602938.2015.1075956.

Winstone, N. E., Nash, R. A., Rowntree, J., \& Parker, M. (2016, January 18). 'It'd be useful, but I wouldn't use it': Barriers to university students' feedback seeking and recipience. Studies in Higher Education [Online]. doi:10.1080/03075079.20 15.1130032

Wu, C. (2014). Flourishing for sports: Well-being of a sportsman from perspectives of positive psychology. Singapore: Partridge.

Xu, L. I. U. (2004). Thoughts on contemporary reform of university curriculum. Journal of Higher Education, 4. Retrieved from http://en.cnki.com.cn/Article_ en/CJFDTotal-HIGH200404018.htm

Xuereb, S. (2015). Academic resourcefulness, coping strategies and doubting in university undergraduates. Journal of Further and Higher Education, 39(2), 205-222. 

Taylor \& Francis http://taylorandfrancis.com 


\section{Part 3}

\section{Successful university teachers and teaching}

The third part introduces success in university studies from the teachers' viewpoint. It continues the theme from the Introduction by explaining how the approach of caring teacherhood may enhance both students' study success and teachers' well-being. The first chapter discusses the elements of caring teacherhood in general. The second chapter focuses on practices of teaching and strength-based approaches in university education as a part of caring teacherhood. In addition, we take a look at online teaching and teachers' opportunities to create a positive and caring online teaching environment. The third chapter introduces the resources of supervision of master's and $\mathrm{PhD}$ theses by focusing on the description of the nodes and strides of successful supervision. How should critical but encouraging feedback be provided during the supervision process, and how should students with diverging motivation be supported to complete their theses successfully? Among others, these will be the questions this part answers. Finally, the part points out the invaluable resource of teachers' and professors' collaboration, caring atmosphere, and mutual support that make the cornerstone of a healthy academic community with high levels of well-being - and that reflects on the students' well-being as well.

\subsection{Caring teacherhood in university education}

\section{The idea of caring}

In this chapter, we discuss how the goals of education could be achieved by using caring teacherhood in university education mainly based on our research in the 'Love-based Leadership - an Interdisciplinary Approach' project (www.ulapland. fi/lovebasedleadership). We think that a particular positive and caring viewpoint could be something that today's university education needs. For example, Cruce, Wolniak, Seifert, and Pascarella (2006) suggest that good practices in education have a unique, positive impact on student development because they can affect, for example, student engagement, which can be seen as one main pillar in successful and meaningful study path.

Good teacherhood has been characterized in several ways at different times (e.g., Lancaster, 1974; Freire, 1997; van Manen, 1991; van Manen \& Li, 2002; 
Korthagen, 2004; Marcos, Sanchez, \& Tillema, 2011). The foci have changed over the course of time, yet there has been something permanent in the expectations as well (Darling-Hammond, 2003; Feiman-Nemser, 2003). In addition to teachers' personality and individual characteristics and collaboration and social skills, substance knowledge has been considered important as well (e.g., Elliott, Isaacs, \& Chugani, 2010; Jakku-Sihvonen, 2005; Wall \& McAleer, 2000). However, the fact that a teacher is capable when it comes to the above-mentioned aspects does not guarantee positive learning outcomes (Parker, Ndoye, \& Imig, 2009). Instead, the ability to help various learners to succeed and be inspired is crucial. A teacher's proficiency is manifested by the ability to look at the subject from a student's point of view, to foresee the critical junctions in learning, and design teaching to meet students' information acquisition and collection processes (e.g., Zombylas, 2007). Thus, a teacher's professionalism results from versatile mastery of the content in teaching (Davis, 1993; Hansen, 2009). However, even this mastery does not seem to be enough.

Indeed, teachers at all levels of education, if anyone, know that emotion-based attachments are bridges between people. Everyone should be able to feel love, caring, and attachment during their whole life, from birth to death (Fromm, 1956). A teacher's ethical caring means genuine caring, aspiring to understand and make an effort for students' protection, support, and development. Because of this pedagogical caring, the teacher especially pursues students' potential to develop and thus help them to find and use their own strengths. This perspective is less often discussed when it comes to university teachers' and professors' work.

Kezar and Kinzie (2006) have introduced features of a quality undergraduate education that have been associated with student engagement: quality begins with an organizational culture that values high expectations, respect for diverse learning styles, and emphasis on the early years of study; quality undergraduate curriculum requires coherence in learning, synthesizing experiences, ongoing practice of learned skills, and integrating education with experience; and quality undergraduate instruction builds in active learning, assessment and prompt feedback, collaboration, adequate time on task, and out of class contact with faculty (see also Kuh, 2003). Likewise, Theilheimer (1991) have presented a detailed list of five factors that contribute to a positive learning environment: (1) comfort (creating a feeling of safety, accommodating errors, giving students the freedom of expressing themselves without constraints, creating the feeling of belonging to peer group), (2) clarity (providing clear instructions, breaking down material to smaller chunks to maintain the feeling of accomplishment, however small), (3) respect (mutual respect between students and the teacher), (4) relationships (particularly caring relationships between the teacher and individual students, teacher attending each student individually), and (5) responsibility (giving students a degree of control over decisions concerning their learning).

We combine the fundamental idea of love with teaching in university education, which we call caring teacherhood (see also Uusiautti, 2013; Uusiautti, Syväjärvi, Stenvall, Perttula, \& Määttä, 2012). Our purpose is to analyze how caring teacherhood in higher education can be used to enhance students' success 
and what its relationship with other factors affecting students' study success is like. Thus, we review love in university teachers' work from the point of view of the students' study processes.

Caldwell and Dixon (2010) have defined love, forgiveness, and trust as organizational constructs that are freedom producing, empowering, and vital to enhancing followers' self-efficacy. The same idea appears applicable to the university setting, too, if we consider teachers as leaders of the classrooms: when teachers consistently exhibit love, forgiveness, and trust in relationships, their students respond with increased commitment to studies. Moreover, happiness can be directly translated into engagement, productivity, and satisfaction (Prewitt, 2003; see also Rego, Ribeiro, Pina, \& Jesuino, 2011). It has been argued that sensitive leaders develop a culture that demonstrates concern for individual needs (Fairholm \& Fairholm, 2000; Popper \& Amit, 2009). Emotions and emotional intelligence have even been considered as the heart of effective leadership (Goleman, 2006). Furthermore, an ethic of caring establishes a moral touchstone for decision making (Hoyle, 2002) because the elicitation of love regards other people as the cause, target, or third-party observer of these emotions (Fischer \& van Kleef, 2010).

Given this perspective on love and teacherhood, we are interested in researching the connection between caring teacherhood and students' study success in universities. This viewpoint contributes to the overall knowledge about caring leadership practices but specifically to awareness of the multidimensional nature of higher education organizations and factors affecting the smoothness of university students' study processes.

\section{The nature of caring teacherhood}

The nature of caring teacherhood in relation to students' successful study processes could be divided into three viewpoints (Uusiautti \& Määttä, 2013a). According to the university leaders' perceptions, they could use caring leadership for (1) providing resources for quality education, (2) seeing students as equal group and promoting the sense of solidarity, and (3) treating students as customers.

The first category refers to the relationship between outer factors affecting education and the way education is realized in practice and provided to students. It is important that teachers and professors consider themselves responsible for ensuring high-quality education and support for students.

The second viewpoint is related to the atmosphere at the unit or department of the university. According to our study (Uusiautti \& Määttä, 2013a), it is important for the students' study success, commitment, and overall satisfaction that the people at each unit and at the university share the sense of togetherness and solidarity. The sense of togetherness can also be seen as the answer to the everincreasing pressures of productivity and individual success. Working together, open interaction, and collaboration in units could benefit not only students and the faculty but the whole organization as well. A well-functioning unit with a 


\section{Successful university teachers and teaching}

good and inspiring spirit can offer the best premises for students' study success and through this, the success of the whole unit and the university as well. We will discuss this in more detail in the Chapter 3.3.

Whereas the previous category described how the sense of solidarity could support students' study paths, the third category takes the thought at the personal level by seeing students as the customers. However, it is not just demands expressed by the customers but merely collaboration and desire to find out what is the best for them through reciprocal interaction: students as customers are simultaneously seen as partners, too. From this point of view, caring teacherhood is considered a means of paying attention to students as individuals, taking care of them at the personal level, and respecting them as the most valuable part of the university. When students are perceived as customers of higher education, they can believe they are being supported and heard. Probably, this idea is more easily applicable in some countries than others. For example, in Finland, university education is free, and therefore, the preliminary idea of a customer-student is not an obviousness, but, for example, in the United States, university education is not free, and one might think that perceiving students as customers is more natural.

When discussing caring teacherhood, the idea of students as customers goes back to the understanding about the purpose of the teachers' work in universities. This is also the question of respecting students. Caring teachers' task is to be aware of their responsibility for students and accept them as their customers, but they also have to be on a first-name basis with their jobs and find their work meaningful in this perspective.

We have previously described the student's study process as a sum of factors at the student's personal level; the unit level; and the overall regulations, values, and cultural traditions that control education. Although they do not explain a successful study processes alone, their development and significance should be paid more and more attention at universities.

\section{Caring teacherhood from the students' perspective}

From the students' perspective, caring teacherhood means that they are valued and noticed at the university. They receive support and guidance when needed and feel respected as an important part of the university. In addition to sufficient support and guidance, there are other means to enhance students' well-being, too. For example, mutual free-time activities that could be provided at or nearby the campus would enhance positive interaction between students and university personnel. Participating in these kinds of activities would also increase student engagement. For example, Kuh's (2003) framework for student engagement is based on five benchmarks: level of academic challenge, enriching educational experiences, supportive campus environment, student-faculty interaction, and active and collaborative learning. Indeed, engagement is one basic concept when considering successful studying.

Naturally, everyone also perceives success in studies subjectively and evaluates personal achievements in different ways (Maddux, 2002). Expectations 
for the future affect greatly how people react to changes and challenges (Carver \& Scheier, 2002), and various strategies lie behind the one that leads to active and meaningful studying. From the perspective of university students' success, it seemed that caring teacherhood can function as a means to support students at their personal level and enable them to find and use their personal characteristics, talents, and strengths in the best possible manner during their studies.

At the unit level, the educators' pedagogical and scientific professionalism, curricula, and the atmosphere and conditions of the unit (see Määttä \& Uusiautti, 2011 a, 2011b; Uusiautti \& Määttä, 2013b) can be named as the core factors leading to success. If the students were regarded as customers, the curriculum would be the product. It should fulfill the promises of education and thus be cutting edge. Basically, the curriculum provides both teachers and students with a clear goal. It answers the questions of what kinds of expertise students will have in the training program and what kinds of study entities they will study along with the study units.

Five stages can be distinguished in curriculum work (see Alaoutinen et al., 2009): (1) to define the basic task and profession of the education, discipline, or art to evaluate the need for education; (2) to define required competencies and general goals of teaching; (3) to define the model of curriculum; (4) to define the goals, contents, workload, and methods for study entities and units; (5) to determine the communication in the curriculum; and (6) to evaluate the curriculum and the proficiency produced by it and its constant development. Learning goals in the curriculum tell what students are expected to know after taking a certain study unit, and they also direct working and the way learning, teaching, and studying are being evaluated.

When pursuing the valued outcomes, students need special support and guidance, and here the equal and open interaction between the faculty and students becomes highlighted. Finding studying meaningful has been noted to have a positive relationship with students' perceptions of academic atmosphere at the unit (see e.g., Kezar \& Kinzie, 2006; Mayya \& Roff, 2004; Pimparyon, Roff, Mcaleer, Poonchai, \& Pemba, 2000). Furthermore, it is a known fact (e.g., Greenwald, Hedges, \& Laine, 1996) that a broad range of resources is positively related to student outcome (see also Atjonen, 2007).

Caring teacherhood in university education can enhance the students' study processes by highlighting some fundamental principles of education. Universities are liable for students, meaning that the promises given in the university's application guides must be fulfilled so that every student feels welcome and becomes convinced that he or she made a good choice when applying for education. On the other hand, the most far-reaching and rewarding part of teaching and mentoring is to make students interested and seize the questions of their discipline and finally become enthusiastic about working for the continuity and development of science (Schunk \& Pajares, 2005). Finally, quality guidance and teaching make a central, valuable part of the whole sphere of academic work. Caring for students is the lifeline of the quality and profitability of higher education. 
Daniel Goleman (2006) has wisely said: 'Leading a school to create a warmer and more connected school culture need not mean sacrificing academic rigor. Instead, socially intelligent leaders help schools better fulfill their main mission: teaching' (p. 81). This concerns university-level education, too. And, based on our studies, we would like to continue Goleman's thought by adding that by using the leadership position for fulfilling the teaching mission, caring leaders also help students and enhance their study processes.

\subsection{Well-structured, positive teaching}

\section{Curriculum planning as the basis of quality teaching in universities}

A university curriculum is defined as a tool to plan and design university teaching and studies (Barnett, 2009). Based on the curriculum, studies should form a wellstructured, harmonious entity. All courses have their own goals, teaching methods, and evaluation principles. In addition to them, the connections between and sequence of courses are written in the curriculum. The ultimate purpose is to provide a framework for students' fluent study paths in which progress can be foreseen and based on which it is possible to make successful personal study plans.

Setting goals is - as mentioned - a central part of a curriculum. What are these goals, what are they based on, and why are these goals set? Basically, three dimensions can be distinguished in a curriculum that are written, taught (executed), and learned (realized or experienced) (see also Jakku-Sihvonen, Tissari, Ots, \& Uusiautti, 2012). All these dimensions can be acknowledged when developing the curriculum and doing quality control of education. For example, it is relevant to ask how well the learned curriculum resembles the written curriculum. Are students learning what they are expected to learn as stated in course-specific learning goals? How much does the hidden curriculum (and its unwritten goals) influence education, and what kinds of contents does the hidden curriculum have (e.g., Margolis, 2001)?

When planning the curriculum, it is necessary to be aware of all the levels the curriculum is supposed to serve: the student level, the teacher level, the university level, the level of work life, and the societal level (Barnett \& Coate, 2005). The curriculum directs students' study paths, sets an example of desired progress, and provides the basis of a personal study plan. To teachers, the curriculum provides a framework within which they plan and realize teaching that aims at pedagogical, scientific, and professional (theoretically and practically) learning goals.

What kinds of knowledge, skills, and attitudes should education produce, and what are the competences that each graduate should possess? What are the abilities, expertise, and know-how the future work life necessitates? Basically, when defining the learning goals, it is necessary to define the core of the education program, the core content of the major that will serve as the common thread through the education. As the flood of information increases and pressures grow, finding this core is probably increasingly more difficult, yet it is extremely 
important because it represents the absolute minimum and necessary contents that everyone should learn and master by graduation.

Analysis of the core elements in curriculum helps defining the program-specific goals and contents and their mutual connections and hierarchies. Based on this idea, the learning goals can be divided into three: (1) the core content that everyone has to master, $(2)$ the supplementary contents that comprise a selection of what details and additions could be included in learning goals, and (3) special contents that may become learning goals only based on work experience or other activity.

The learning goals can be defined, for example, by leaning on the so-called Bloom's taxonomy (Bloom, Engelhart, Furst, Hill, \& Krathwohl, 1956):

1 to remember: the ability to remember things as they were presented (to list, recognize, organize, describe, define)

2 to understand: the ability to understand and interpret what was learned (to categorize, explain, interpret, mold, evaluate, summarize)

3 to apply: the ability to use information in new situations and in problemsolving situations (to apply, use, construct, solve)

4 to analyze: the ability to cut a problem into smaller units and understand their mutual relationship (to analyze, choose, compare, criticize)

5 to evaluate: the ability to combine (to plan, develop, generalize, reorganize)

6 to create: the ability to create something unique and new, the ability to assess the value of ideas and solutions (to conclude and reason, recommend, verify, choose, justify)

\section{Successful planning of teaching}

As the aforementioned introduction about curriculum planning suggests, successful teaching leans greatly on a well-planned curriculum. Based on it, a university teacher can define learning goals for each course, choose contents he or she will be teaching, select suitable teaching methods, and determine how learning will be evaluated. Actually, the teacher has numerous questions to answer when planning teaching: Who will the students be? What kinds of abilities and knowledge do they already possess? What would be the best way to teach them - in a teacher-led manner or by activating students? How can the availability, applicability, clarity, and multiformity of learning materials be ensured? How should students' learning be evaluated? How can the teacher pay attention to feedback from students and give response to feedback? How does the course fit in the entity of studies, and what kind of a picture does it give about the profession or the field of science? (Lindblom-Ylänne, 2004).

After answering these questions, the teacher starts teaching. Suitable teaching methods can be lectures, introductory speeches, internet-based and varied teaching, simulations, seminars, supervision, evaluations and feedback, work and teaching practicums, learning tasks and essay writing, excursions, visits, learning games, drama, and so on. There are multiple options! 
A very basic teaching method in universities is lecturing. Based on a caring viewpoint, a lecture is successful if the lecturer respects the audience, tries to foresee their hopes and needs, and spends time in preparing lectures. Naturally, the teacher's own interest in the theme is crucial, too.

Lectures always include a beginning, intermediate phase, and ending (the socalled climax of the lecture). A good lecture (1) has a start that ignites interest in the audience, $(2)$ proceeds logically and in a well-constructed manner, and (3) has a thought-provoking and impressive ending. However, none of these are possible if the teacher has not studied the theme sufficiently, meaning that constructing a good lecture requires plenty of work, such as reading the latest research articles and literature, checking one's previous information and knowledge, and putting pieces together. Little by little, the theme as a whole becomes clear, and the teacher can choose the most important contents to be included in the lecture.

Lecturing and verbal communication are different than written expressions. The audience is listening to the lecture as a continuous flow in which there is no rewind option. Therefore, it is necessary to stick to the important contents without losing track too much. However, if the teacher is able to repeat the most important parts in different words, the audience has more time to internalize the new information. If the lecturer discusses themes too fast, presents contents in too a difficult manner, or has slides filled with small text, learning will not be optimal (Biggs \& Tang, 2011). Positive interaction with students is important when lecturing, too (Kumar, 2003).

Lecturing aims at transmitting different viewpoints and theories so that the students can actively analyze and discuss them (Biggs \& Tang, 2011). Often, the basic concepts and theories are taught in lectures after which self-directed studying of text books and advanced material becomes easier for students.

Almost every teacher is nervous about holding a lecture. This is quite normal and may be due to various reasons, such as previous negative lecturing experiences. Careful planning serves the teacher, too. Not only can the teacher feel more confident, but also students respect teachers who have a message, who have prepared their lectures with care, who pay attention to their audience, and who believe in their errand. Careful preparation makes also flexibility during lectures possible if the situation needs it. Lecturing is an interaction situation during which the lecturer can get support and new viewpoints to his or her work and share them with the audience. The teacher can promote the emergence of a positive and encouraging atmosphere by his or her own way of interacting with students (Määttä \& Uusiautti, 2011a, 2012). At its best, interaction with students supports the teacher's learning, too, and enhances well-being at work in general.

\section{Teachers as tutors}

There is plenty of research about the benefits of teachers acting as tutors for students (Määttä, 2014; see also e.g., Burns \& Sinfield, 2004; Field \& Field, 1994). The concept itself is complex, originating from a Latin word 'tutor'. The Finnish translation of the word merely means an observer, and for example, Lehtinen and 
Jokinen (1999) has interpreted that a tutor is a compassionate guardian. Regardless of the word used in practice is, tutoring as a main concept means systematic, determined, and flexible guidance by experts and teacher-student interaction aiming at facilitating each student's fluent study progress, socialization in the academic community, and independent achievement of learning goals.

Teacher tutoring is an important part of the university supervision system. For example, at our home university in Finland, every student has a teacher tutor and a student tutor. The teacher tutor is nominated by the faculty, and the student can contact the tutor whenever she or he needs help or personal guidance. The teacher tutor is motivating, encouraging, guiding, and advising. The purpose is to secure an efficient start-up of studies, fluent progress in studies, and development in scientific thinking and to avoid wrong choices and prolonged studies. Tutoring is also supposed to support independent action, activity, motivation, and integration in the academic community. In all, the goal is to make sure that the goals are being met and students graduate in a reasonable time. Thus, tutoring helps efficient, well-planned, and quality studying that is also motivating (Määttä, 2014). At its best, interaction between the teacher tutor and a student supports the student's participation in the academic community and his or her own field of studies, strengthens the student's development in academic studies and self-directedness, and prevents undesired choices and prolonged studies (Mäkinen, Olkinuora, \& Lonka, 2004). Määttä (2014, p. 9) has described the emphases of tutoring as three overlapping dimensions (see Figure 3.1): in the point they overlap each other, the student's optimal growth emerges.

Successful personal study planning conversation requires five basic tasks from the teacher tutor (see Laitinen, Pekonen, \& Pirttimäki, 2009):

1 to create a confidential atmosphere that makes open discussion possible;

2 to discuss and analyze together the issues and problems that the student brings out;

3 to design and built methods that aim at increasing the student's own responsibility and control over problematic situations;

4 to follow and evaluate the conversation; and

5 to conclude the conversation by making sure that the teacher tutor and the student agree about the solutions and next steps.

According to Nummenmaa's (2008) studies, students consider conversations the least successful when the teacher tutor has been distant and cold and the conversation has not had any clear structure. Therefore, it is not enough that the relationship and interaction between a tutor and a student are warm and kind. Guidance has to be well-structured. It is worth noticing that tutoring can happen face to face or online, too.

Online tutoring is pedagogical activity that can have a functional, interactional, and reflective form (Laitinen, Pekonen, \& Pirttimäki, 2009; see also Uusiautti \& Määttä, 2014). Functional guidance means that the tutor gives advice or is available to a student or a student group. The student gets sufficiently real-time 


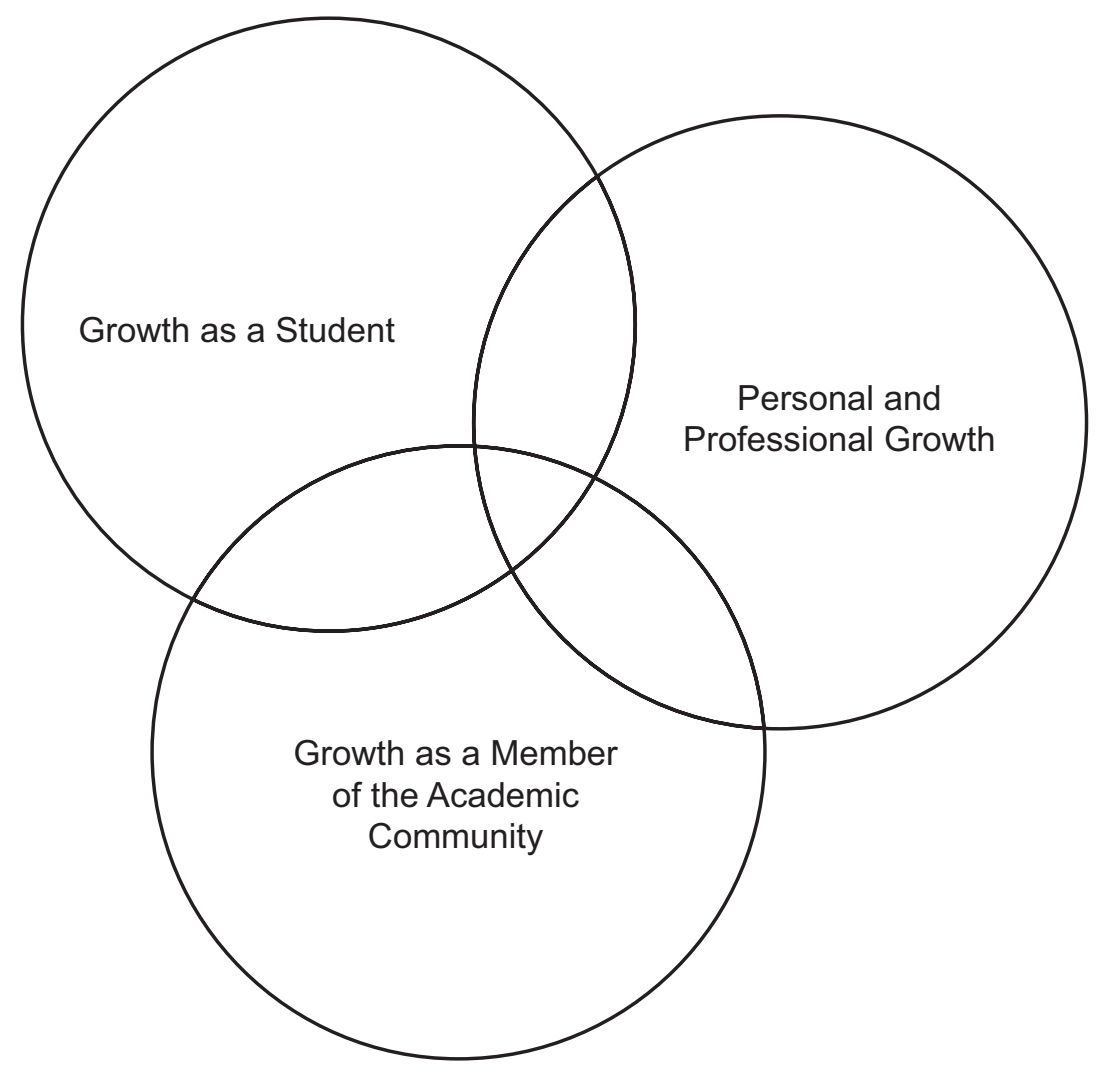

Figure 3.1 Emphases of teacher tutoring (Määttä, 2014, p. 9)

information and guidance in order to successfully progress with studies. In the interactional sense, whereas the network serves the means of interaction, reflective tutoring supports the student's aspiration to understand the situation. Reflectivity necessitates a certain kind of approach that pursues activating the student with open-ended questions, questioning of conceptions, and deliberations (Laitinen, Pekonen, \& Pirttimäki, 2009; Mäkinen, 2007).

Different students need different kinds and levels of personal tutoring. Thus, it is good to have various forms (e.g., face-to-face or phone conversations, emails, online systems) available. The main point is to have tutors who students can turn to without hesitation. From this perspective, it is crucial that teachers also find the most suitable ways of realizing tutoring.

Based on research, an active and positive interaction is the key of tutoring. Views on the importance of interaction is also shown in numerous surveys among students (e.g., Uusiautti \& Määttä, 2014). Adjustment and engagement to the university necessitates vivid interaction inside the university, with the university personnel. Positive interaction makes the atmosphere positive, too. 
The research also shows that students would like to have more interaction with the teaching staff. They also report that contacts with teachers are mostly positive, but too scarce (Säntti, 1999). According to the Finnish university student health survey (2008), only little over half of university students believe that they belong to a group. Lähteenoja's (2010) doctoral research showed that more than half of new students had never visited teachers' offices for appointments; asked or received feedback about exams from teachers; or discussed scientific questions, study progress, or future plans with teachers.

Although it is important to invest in tutoring at the beginning of studies, students do need support and guidance also throughout their education. The goal is that students could progress fluently and that the structure of education would be functional and meaningful.

At the beginning of their studies, the flood of new things seems like chaos to students; therefore, they do not even know what to ask. As their studies get started and all practical matters become clearer, they will have more questions. This is the time that teacher tutoring is the most important. Still, it is not selfevident that students dare to ask questions from teachers when they have concerns or trouble. This is why the teacher's active willingness to interact is crucial.

On the one hand, students, who do well, proceed the fastest, and want to do even better benefit from tutoring the most (Lindblom-Ylänne, 2004). Therefore, students who have actual problems get the least benefits. They do not always recognize their problems or cannot see the value of tutoring and the advice they are given by teachers.

As students' self-directedness increases, the need for tutoring decreases. However, students have to make several choices during their studies. In addition, they may face various challenges or adversities that they would like to - and should discuss with teacher tutors.

In sum, tutoring in its various forms should be a natural part of university teachers' work. Good tutoring is rewarding in many ways. Students start their university studies being happy, proud, and hopeful about their special study place. However, joy and relief are accompanied by numerous doubts, questions, and concerns. If tutors are able to help and create positive relationships with students, students study and graduate fluently. Teachers' work bears fruit in the future researcher generation. For teachers, tutoring provides a sense of meaning in work, positive relationships with students, and collaboration. Furthermore, tutoring can decrease teachers' workload if tutoring is realized systematically and planned well. A good balance is necessary: students should learn to be responsible for their studies, but the university should be able to provide sufficient, timely, and accurate guidance so that students can succeed in their university studies the best (see also Lindblom-Ylänne \& Nevgi, 2009; Moitus et al., 2001).

Every year, more than 8,000 university students quit their studies in Finland, which is about $6 \%$ of all university students. Thus, the number of quitters is high. Naturally, the reasons for quitting are abundant: the study field can prove to be wrong, guidance is deficient, changes in personal life lead to quitting, or one can 
go to work permanently. Some of these students come back but not everyone. From the perspective of a university, every student who does not graduate is a loss.

Of course, the ideal situation would be that young people could make the right choices; would be aware of their talents, strengths, and interests; would know the available options well; would start higher education straight after high school; would graduate in time; and would become employed straight after graduation. More often than not, the reality is different. Some youngsters think they know what they want but become disappointed. But as our studies have shown, it is possible to improve: it is possible to support students in their studies, point out their strengths, encourage them, and enhance their well-being and resources - to make their studies successful in the university.

\section{Strength-based teaching}

In addition to tutoring, teachers interact with students when teaching, which is probably the most natural element of a teacher-student relationship. In this chapter, we will briefly discuss the idea of strength-based teaching in greater detail as an example of how to pay attention to students' strengths and resources in teaching in a way that supports their well-being and achievements in studies.

Strength-based teaching is a concept that is often associated with basic education but is very well adaptable in higher education in various ways (e.g., Anderson, 2005; He, 2009; Schreiner \& Anderson, 2005). It is a concept that provides a useful theoretical viewpoint to analyze teaching that could support students' study success optimally (Carman, 2005; Linkins, Niemiec, Gillham, \& Mayerson, 2014; O'Connell, 2006; see also Liesveld, Miller, \& Robinson, 2005; Yeager, Fisher, \& Shearon, 2011). It is based on the idea that all students have strengths, resources, and the ability to recover from adversity, and it attempts to identify and appreciate students' internal strengths and resources (see also Salmela, Uusiautti, \& Määttä, 2015), also when dealing with problems and adversities that occur in each and every student's study path (Linkins et al., 2014; O'Connell, 2006).

Earlier we talked about how the curriculum directs university teaching in practice with its goals, contents, evaluations, and overall study structures. If the purpose is to make sure that students learn the important core contents the best, it would be reasonable to focus on their strengths rather than weaknesses (Carman, 2005). In strength-based teaching, teachers try to perceive students as they are and learn about and bring forward their unique strengths and opportunities. Seligman (2011) has found out that when focusing on recognition of students' signature strengths, students can flourish. According to studies (e.g., Liesveld et al., 2005; Linkins et al., 2014), this can increase study motivation and enhance positive learning processes.

A strength is a positive feature that describes a person at his or her most genuine (Linley, Willars, \& Biswas-Diener, 2010; Rath, 2007; Seligman, 2002). Strengths can be manifested in many ways (Yeager et al., 2011), but the main characteristic of a strength is that it brings joy and satisfaction when used, but 
also the element of achieving and performing as well as the sense of mastery and flow are connected to signature strengths (Linley et al., 2010). Therefore, strength-based teaching includes the viewpoint of not only students' happiness, satisfaction, and well-being but also achieving and succeeding (see also Pajares, 2001) and efficient and quality action (see Quinlan, Swain, \& VellaBrodrick, 2012; Wood, Linley, Maltby, Kashdan, \& Hurling, 2011).

The basic idea is find teaching methods that pays attention to various learners' needs (see also Best \& Thomas, 2008). Also, methods of collaborative learning can be fruitful and boost successful learning in students (see Hyppönen \& Lindén, 2009). Usually, a group of students gets a task or a problem that they start to work with. Thus, collaboration with others becomes significant in order to have the group work fluently and in a balanced manner: each student's input is crucial, information must be shared, and mutual learning is necessary to a successful completion of the task.

\section{Positive online teaching and learning environments}

Positive and strength-based teaching is not limited only in face-to-face encounters with students (Maor, 2003; Niemi \& Multisilta, 2014) More and more teaching takes place in online environments, too, and especially for university students, the flexibility that these teaching arrangements provide has become very important (Bouhnik \& Marcus, 2006; Lindstrom, 2012; Tallent-Runnels et al., 2006). Online teaching enables participation regardless of place and usually, for example, lectures can also be watched afterwards and again and again from recordings. As noted, there are many studies about the benefits of online teaching arrangements, but of course, some disadvantages exist, too. One of them is the lack of direct contact with the teacher and other students: because quite a bit of human interaction is actually nonverbal, online interaction becomes somewhat limited in this sense (Stacey, 2002; Tian, Yu, Vogel, \& Kwok, 2011). But how do university students themselves perceive online teaching?

We asked university students to describe their experiences of online teaching. The purpose was to find out how their perceived the teacher's action in such environment and how they would describe, for example, interaction with the teacher and other students (see also Swan, 2002). As the chapters in this book have also showed, positive interaction is one of the main factors in successful study paths; therefore, as the possibilities of online teaching increase alongside demand on it, it is important to know student perceptions and experiences widely. In addition, we wanted to know what kind of an online learning and teaching environment would be ideal according to students' opinions.

\section{Positive and negative features}

University students were consistent in their descriptions of positive and negative learning experiences in online teaching. Clearly, the most important positive factor was the teacher who paid attention to students in the online environment. 


\section{Successful university teachers and teaching}

This was mentioned by 15 students of 34 research participants in our data. The ways of paying attention included the ability to design a clear course content and guidance. Good planning was thus appreciated widely by students.

It was a really good entity, in my opinion. The well-designed slides were visible all the time, we had the opportunity to participate in conversation and even ask in the middle of lecturing, the lecturer appeared in the real-time video the whole time. We had been given tasks to read before lectures and we discussed based on them.

(Student no. 22)

Teachers are able to use the online environment. The lectures are well planned, slides are short enough, and slides are also shared in the online learning environment, and thus they are available later on, too. Also other course materials are being shared in the online learning environment and available during the whole course.

(Student no. 14)

Quite many students mentioned that it was good to see the teacher via online video connection. In addition, they had positive experiences of it because the teacher's own interest and enthusiasm about the subject could be better transmitted to students. This finding is similar to that of Stacey (2002), who found out that the teacher's 'affective' behavior, including humor, emotion, and self-disclosure, were a style of communication that appealed to students in online teaching.

In our data, positive teachers also showed caring by giving proper guidance about how to use the online classroom and other learning platforms. Likewise, during lectures and online teaching in general, students appreciated if the teacher reacted, for example, to students' comments and questions in the chat window immediately. This increased their sense of participation but also enhanced interaction with the teacher and provided a feeling that the teacher really wanted to involve students in learning.

In addition to slides and the teacher, the participants could comment in the chat window with their questions and opinions in real-time. What was especially nice was the teacher's good teaching style: calm and clear! Also her presence was all the time joyful and positive. Slides were clear, and the teacher complemented the slides with her speech!

(Student no. 11)

If the positive teacher's action was considered the most important feature of positive learning experiences in online teaching, the second most commonly mentioned feature $(n=12)$ was interaction with others, peer students. Positive learning experiences happened in online courses were students were able to interact with each other during lessons in private chats or online group conversations. Some had experiences of online interaction before and after lessons in a special online discussion groups, but often they did not include real-time conversations. 
Most online learning environments allow the teacher to divide participants into groups (randomly or not), and the groups can have their private discussions with microphones or in a group chat. Positive experiences included especially these kinds of discussions with peers:

It was good that we could think about the issues together even though we were not in the same room. It was also positive that the teacher determined the groups. This way we had different kinds of viewpoints than usual, because usually in lectures you do group work with the same peers.

(Student no. 26)

I have positive experiences. Group discussions were new to me. A really good thing! More this!

(Student no. 7)

Sharing thoughts and opinions is therefore important to students, even if they participate in lessons 'from their home couch in a nice position' (Student No. 22). Interestingly, students mentioned that the opportunity to be anonymous in the online learning environment could help open interaction and sharing of thoughts and ideas. Although some would have preferred students' names and profile pictures available, some thought that participation anonymously in chat or other discussions increased their attention and voluntary participation.

Discussion succeeded as well in the chat as - or even better than - in a normal lecture hall (Finnish people warm up slowly, and if there are no familiar people, no discussion will happen) $\rightarrow$ anonymity in the online chat $(-)$

(Student no. 9)

In an online lecture, it is easier to express your opinion and group discussions are more fluent because even we who are shy find it easy to type our opinion on some topic without drawing too much attention to ourselves. In addition, everyone can read the comment again because they are available in the comment box.

(Student no. 12)

Students clearly expressed their need for discussing the topics and themes with peers in addition to the teacher. We will discuss this more in the next chapter.

Other positive experiences from online teaching included the opportunity to participate in the course regardless of place (nine students mentioned this). Some were traveling by car or train, some were in their summer houses, some cooked and took care of children, or some just laid comfortably on their home sofas. This advantage was quite expected among students from the University of Lapland: students come from across the Finland, and even in Lapland, the distances between students' homes and the university can be hundreds of miles. Winter time is also hard. During the time of plenty of snow and freezing temperatures, students seemed to appreciate the chance of staying at home and not driving in hard conditions to the university. Even though not all universities are located in 
places like the one in our example, this benefit is clear: students can also participate more actively, for example, if they are sick, and would not want to miss any lessons. Some students $(n=8)$ noticed that they participated more actively in lessons, too, in online teaching:

Yes, I have positive experiences of online teaching. It allowed me to make an optimal space, make myself comfortable, have breaks and I could concentrate better than in an ordinary lesson.

(Student no. 5)

When the students were asked to list negative experiences of online learning environments, their answers were consistent with those previously presented. However, the worst experiences were connected with technical problems $(n=15$ students). Lousy connections and thus problems with video, pictures, and voice were considered annoying. However, the students had realized that more often than not, the problems occurred in their own smartphones or computers and were issues that the teacher of the university could not help with. Of course, the technical part of online teaching is improving all the time, and these questions as such are not relevant to discuss in detail in this book.

Based on students' perceptions and experiences $(n=8)$, lack of a peer group had caused many negative experiences of online teaching. As mentioned earlier, being able to interact with other students is invaluable even in online environments, so it was logical that lack of any interaction was mentioned as a negative experience.

It was not so communal, because you could not see other students.

(Student no. 30)

I considered it troublesome because the peer group was missing. We had some discussion in chat but it was still different than talking face-to-face.

(Student no. 8)

Likewise, six students had negative experiences of not being able to interact with the teacher. They reported about courses where they did not have a live picture of the lecturer, and thus the teacher seemed distant. In some cases, the teacher had used a negative tone in interaction or the teacher had been passive and not responding to students' questions or comments. All these together - technical problems and lack of interaction with peers and teachers - were reported to decrease motivation and attention. Thus, they are also features that teachers cannot pay too much attention when planning online courses.

Online teaching itself is something that I do not like, because the teacher is not present, people are not present, the connection is lousy, you can hear some words but not all. Working online is downright nerve-wracking.

(Student no. 27) 
The benefits and problems brought up by our students are somewhat similar with findings from other studies. For example, Bouhnik and Marcus (2006) listed particular factors that can be used for predicting whether a student might drop out of, or otherwise fail to achieve satisfactory results in an online course. These were clarity of design, interaction with instructors, and active discussion in the context of the course; a lack of self-motivation and the inability to structure one's own learning; an absence of previous experience with distance learning; and forced participation in distance learning (see Bouhnik \& Marcus, 2006, p. 300).

\section{Interaction}

As the students described, interaction with the teacher and other students became one of the most important issues in online learning. When asking directly about their experiences of interaction with the teacher, students reported that in many courses, interaction was instant, fluent, and positive. Some teachers had the ability to create a positive learning atmosphere also in online teaching and encouraged students to participate and interact with their presence and willingness to hear students' opinions and comments. Of course, teachers differ from each other, and not everyone finds it easy to interact in an online environment. From a student's perspective, creating opportunities to become seen and heard also in online learning environment is crucial and increases study motivation and thus successful studying, too.

[In a good course] the interaction is very good. The teacher seems to be aware of things, can have appropriate breaks and read students even remotely, and is not too official but when the teacher is open, it is easier to approach the teacher with questions.

(Student no. 6)

I dare to ask better in online teaching than, for example, in a lecture hall. Even though in a lecture hall the teacher is present in the same room, in the online environment the teacher feels closer.

(Student no. 13)

The teacher can show his or her interest in students' learning and participation by commenting on their contributions and participation during online teaching. Students can be activated by encouraging them to share, for example, internet links they find relevant or interesting. The teacher's own activity becomes thus evident to students:

The teacher had a real-time video of her so she felt more real. In addition to this, the teacher reacted to all chat-messages the students sent during the lesson. However, it did not interrupt the lesson or take it to wrong direction. Every now 
and then, we watched things from the internet that the teacher had linked to us and we discussed them in the chat.

(Student no. 24)

Interaction [with the teacher] is good because in online teaching it is easier to discuss with the teacher via the online chat option. Many students may find it easier to ask something via chat than aloud during a normal lecture. In addition, we can share links to different interesting articles that everyone can check in their own pc.

(Student no. 26)

Some students had found interaction with the teacher superficial. However, based on the findings from these data, the teacher's ability to engage students in different ways to learning can be the basis of successful online teaching and learning.

Another major feature is, then, the interaction with peers. When students described their interaction with peers, the experiences varied from good and vivid to distant and weak. Those who had the latter type of experiences had participated mainly in online teaching in which there were no opportunities to interact with other students. Here, the positive experiences are interesting: students found online, real-time group discussions pleasing and beneficial. They could share their thoughts anonymously or non-anonymously depending on a course and learn about different viewpoints to topics presented in their courses.

You can reach quite strong interaction during group discussions and working.

(Student no. 17)

Group discussions in chat. For me, this was totally new, this kind of discussion and I was a little slow but we had good conversation though. Other students also linked articles from the interned which gave us new viewpoints to the theme.

(Student no. 24)

Chatting in online lessons can happen in open chat window that is visible to all participants, in group chat windows that are visible to only group members, and as private chat that is visible only to those who are included in the private chat. Some students reported that they used the private chat option to talk to each other during an online lecture. This kind of activity can be compared to students' mutual whispering during a traditional lecture in a lecture hall. However, in an online environment, it is not visible to anyone else - not even the teacher - and does not disturb teaching. Perhaps private chatting may increase students' sense of togetherness in an online teaching environment:

Again I want to highlight group discussions as a good example. We do some commenting with peers in chat in our own bigger group. This chat makes it possible to share thoughts during a lecture with other students without such an 
intermption that 'whispering' with others during an ordinary lesson would do, even though 'whispering' was related to the theme. (-)

(Student no. 25)

\section{Ideal online teaching and learning environment}

Based on our interpretation, an ideal online teaching and learning environment includes three main features: (1) an active, positive teacher who shows caring for students; (2) opportunities to different levels of interaction with peers and the teacher; and (3) good, functional technical solutions and internet connections. When the students in this study were asked to describe an ideal online learning environment, they summoned up all the features they had brought up in other questions. Naturally, they wished for good connections and well-working equipment that form the physical basis for successful studies. But the other two elements are those that the teacher can pay especial attention.

There are numerous handbooks and manuals that describe in detail how to create an online learning environment that is visually attractive, functional, and transmits all the necessary information to students in an optimal manner (e.g., Kearsly, 2000; Maor, 2003; White, 1999). From the perspective of this book, it is more relevant to discuss the attitude that the teacher must adopt when teaching online. The teacher may ask her- or himself, among others, the following questions: How do I make sure that students find me easily approachable and present in an online teaching situation? How can I encourage students to interact not only with me but also with each other? How can I provide opportunities to positive interaction and create a positive online learning atmosphere? As in any teaching, the teacher must pay attention to different learners as well as he or she can and provide support to those who need it the most. Clear guidelines and directions, well-planned courses, and timely feedback are necessary in any teaching but become accentuated in online teaching in which the teacher has to put extra effort to have students engage and participate in lessons. Through active participation, learning also becomes more meaningful and provides positive experiences to students (see also Bosch, 2009; Silius et al., 2010; Uusiautti \& Määttä, 2014). As the proportion of online courses increase in universities, their role in students' study success is becoming more and more important, too. This was also noted by Greg Kearsly almost 17 years ago. He noted that online teaching in virtual classrooms is very different from a traditional lecture hall, but the teacher's ability to use interaction-related tools variedly in online teaching can positively influence the success and the satisfaction of the students who participant in these kinds of courses (Kearsly, 2000; see also Bouhnik \& Marcus, 2006; Tian et al., 2011). Actually, 'social presence is one of the most significant factors in improving instructional effectiveness and building a sense of community' in education, says Steven R. Aragon (2003, p. 57).

At the same time, online teaching can be compared with so-called mass lectures. If we think about the second feature of a successful online teaching - positive 
interaction with the teacher and peers - it became evident that students need this kind of interaction. This was emphasized in every students' answer in our data at some point. However, interaction is not very active or reciprocal in mass lectures either. In this sense, online teaching can provide even more opportunities to share thoughts and opinions with peer students or even with the teacher. In private chats, student interaction may, indeed, become vivid and reciprocal! More research on this topic is obviously needed.

In sum, from the point of view of students' study success, the need for positive relationships, open interaction, and availability of support, from peers and teachers, is valuable in the times of efficiency pressures and increasing mobility and virtual communication. Despite many benefits, students also need face-to-face contacts, and online teaching cannot ever replace these contacts totally. However, having various methods available and complementing each other, it is possible to offer students flexible study paths with numerous chances of successful learning and studying.

\subsection{Resources for the successful supervision of theses}

\section{The special features of supervision}

The supervision of theses forms an important part of work and studies at the university. In this chapter, we discuss mainly the supervision of master's and $\mathrm{PhD}$ theses. Ultimately, the supervision of doctoral theses differs from the supervision of other theses. In this supervision relationship, the supervisor's and doctorate's positions are special because of the high expectations and workload they are going to face for a long period of time. However, certain similarities do exist, and the supervision relationship between the professor and student is sensitive in both cases.

When compared with teaching, supervising is merely considered as consulting. Yet the supervision of theses does also include many similar roles, which are adapted by a supervisor regardless of the grade of the theses he or she is supervising. A supervisor can be a guide, spokesperson, adviser, co-worker, tutor, supporter, protector, backup, referee, leader, manipulator, observer, comforter, feedback provider, critic, facilitator, planner, creator, organizer, manager, friend, and examinator. From a student's perspective, numerous guide books and manuals are available to help with research work and thesis writing. However, these resources mainly focus on the research work and actual art of writing and not so much on the relationship with the supervisor. Yet this relationship can be considered the cornerstone of the whole process and the key to the eventual graduation as a master or as a doctor.

Thus, in this chapter, we continue the introduction of caring teacherhood by viewing the supervisor's work from this perspective (see also Parry, 2007). Actually, the supervision of doctoral theses is still little studied (see, e.g., Mullins \& Kiley, 2002), but the number of research projects is increasing all the time (Gardner, 2007; Knight, 2005). The development of the supervision of doctoral theses, 
expectations, authority relations, the doctors' employment, and the conceptions of good supervision and its problems are widely published from the doctorate's perspective both in Finland and abroad (Bolker, 1998; Booth, Colomb, \& Williams, 2003; Boud \& Lee, 2009; Cryer, 2003; Cullen et al., 1994; Delamont, Atkinson, \& Parry, 2000: Dunleavy, 2003; Evans \& Kamler, 2005; Golde, 2007; Murray \& Moore, 2006; Philips \& Pugh, 2005; Taylor \& Beasley, 2005).

In this chapter, we will discuss the resources needed in supervision based on our earlier research and practical experience (see e.g., Määttä, 2012; Määttä, 2015; Määttä \& Uusiautti, 2012; Määttä, Uusiautti, \& Määttä, 2014; Uusiautti, \& Määttä, 2013a, 2013b). What are the key elements of good supervision from a supervisor's perspective?

\section{A good supervisor}

We have categorized the features required for supervision of theses into four resources. These resources are illustrated with the form of a cloudberry (see Figure 3.2). The elements of knowledge, proficiency, will, and actions are the four fundamental features of supervision - and corresponding characteristics explain the smoothness of a student's research process as well. Here, the elements each form one seed of a cloudberry, and together, they constitute a whole berry, a functional supervision.

As we know, the seeds of a berry are of different sizes and shapes in nature, and therefore, the cloudberries differ too. A supervisor can emphasize an element depending on his or her own style and on the doctorate's work habits and supervision needs. However, the supervision is not likely to succeed if one of the seeds, the elements of supervision, is totally missing.

First, will means the supervisor's commitment to the supervision. Knowledge refers to his or her substance knowledge or the mastery and ability to comprehend the overall structure. Actions are needed to ensure that the contents of research meet the scientific quality requirements. Proficiency includes positive and supportive supervision methods and the supervisor's personality.

Finishing a thesis requires the same resources from a student, too. From this point of view, will refers to the student's commitment to complete the thesis, and knowledge means the ability to make oneself conversant with the thesis' subject matter. Without proper actions, the thesis cannot be built according to the scientific quality requirements. The student's proficiency concretely covers his or her ability to write a thesis; positive and appreciative working methods; and perseverance, persistency, and talent. By outlining the shape and area of one's own berry, every supervisor and student should recognize and assess her or his own resources and possibilities to develop. The supervision relationship can be concretized if a supervisor and student compare each other's cloudberries. The berries are likely to differ from each other as do berries in nature, but if the supervisor and student are ready to discuss their mutual resources, their discussion might turn into an interesting conversation that reveals the reciprocal expectations and gives a direction to the whole research and graduation process. The conversation could be 


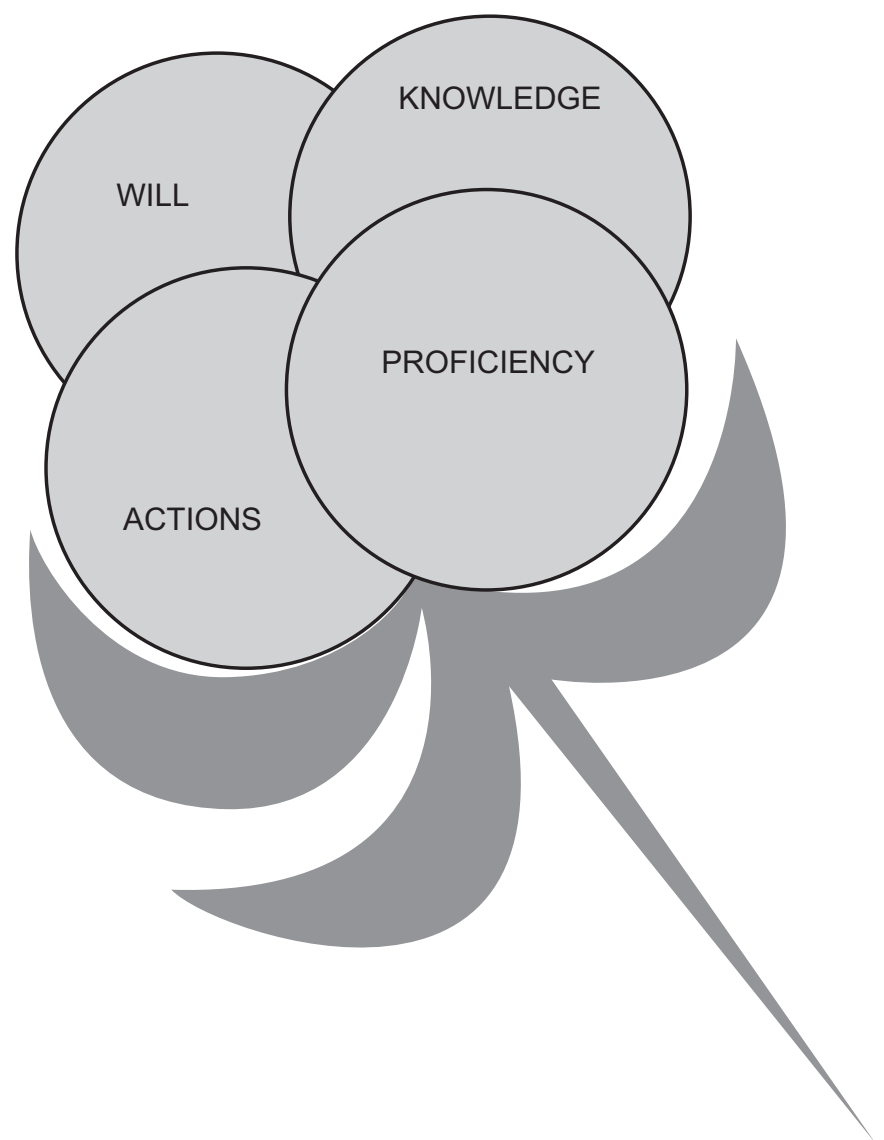

Figure 3.2 The elements of supervision relationship (adopted from Määttä \& Uusiautti, 2016, p. 182)

either informal or formal, but it will form the basis to a supervision agreement between a supervisor and student, which defines the rights and obligations for both of them or the basic conditions of a supervision relationship.

Next, the four elements will be introduced in detail.

\section{Will}

A process of completing a thesis proceeds like a funnel of an hourglass. Getting started is often difficult, there are many options to choose from, and students tend to feel uncertain at first. The emphases of supervision alter during the process. After having made the basic choices and definitions about the structure and contents; research work finally gets started; and the doctoral student will be able to put his or her heart into research theory, methodology, and practice with a 
new kind of certainty. At its best, work is enthusiastic and engaged, encouraged by the supervisor.

During the research process, the supervisor will notice how the mutual relationship between a supervisor and student changes and varies. At the beginning, the relationship may include high levels of admiration and respect. However, along with the process, it is not always possible to avoid disagreements. These disagreements and distress can be avoided or solved the best by being aware of the transformations in the supervision relationship during the dissertation process. The supervisor's commitment and professionalism become evident in not abandoning or neglecting the supervision easily - even when feeling that the value of supervision has been nullified. The more committed one is to supervision, the more satisfaction the completion of a thesis will give to the supervisor.

Along with putting his or her heart into the thesis work, dealing with a student from phase to phase during the process, and learning to know the student, a supervisor develops into an attentive translator of the student's feelings. A committed supervisor has to deliberate constantly how to help a student discreetly with both constructive and respective tone. How can the supervisor be critical while also being a safe mirror to a student who is struggling with his or her research?

As the substantial content of a thesis advances, the ability to supervise and to be supervised constitutes a continuous challenge; this concerns especially the supervision of $\mathrm{PhD}$ theses. Both a supervisor and student individually and together have to constantly question the perspectives that arise. The thesis changes in the pendulum motion of constantly recurring choices, reflections, and options. The first thought of a research theme is probably already inadequate at an end of the work. The context of a completed thesis is just a glimpse of the idea from which the work started.

In the end, a student has the responsibility for the solutions and choices. What a supervisor says is not usually unquestionable but merely suggesting. Still, the supervisor's role is a very responsible one.

\section{Knowledge}

The supervisor needs not only the substance knowledge in the area of research but also knowledge of how to structure the research and organize a thesis as a whole. How can this knowledge be transmitted to the student?

\section{The ability to ask and suggest}

It is important that a supervisor has the ability to ask because good questions make a student realize the quintessence of the work. Furthermore, questions will be better concretized if a supervisor is able to suggest alternatives, giving a student the responsibility to make decisions. Both a supervisor's and student's questions are important in the supervision process. The questions lead to answers, even if the answers were not the best or the most well-defined ones immediately. 


\section{Successful university teachers and teaching}

Already when asking a question, one gets some kind of answer or refines the questions. There are relatively abundantly source books about designing good questions and question types to help the supervisor (Klein, 1999; Koshik, 2002; Lea \& Street, 2000; Martin, 2004; Vehviläinen, 2001).

The language used in supervision and the questions concerning a thesis change during the supervision process. Thus, a supervisor may reflect and consider the nature of questions and how the questions will become more complicated during the process. What questions are the most crucial at the beginning, and what kind of questions enhances the quality and advancement of the work?

\section{The concreteness of supervision}

Many times concretizing supervision and securing the process require not only verbal feedback but also written directions. Even so, a student's ability to accept or hear the feedback and a supervisor's skills to give feedback do not always meet. Mutual misunderstandings are surprisingly common.

Despite being laborious, written feedback has its special benefits. A student can read the written advice, suggestions, and feedback in peace and is able to come back to those again and again, to reflect and dwell.

However, discussing face to face and comparing notes together are invaluable. At its best, a supervising meeting ends with a following question: 'What are you going to do next'? This kind of checking also guarantees mutual understanding about the direction on which the work will proceed. It presents a way to gather up the supervision conversation and gives both to a student and a supervisor an opportunity to correct misreading.

\section{Criticism without discouraging}

Although a student knows that the evaluation is related to the scientific working, one might still be surprised by the criticism being so touching, even if it were given by the supervisor. After working at the limits, revision suggestions or demands can hurt, and one tends to defend oneself or underestimate these correction suggestions. The more concrete an evaluation is, the easier the criticism is to perceive as feedback that helps to improve the research. At its best, the corrective feedback makes one think: 'Why didn't I notice this myself'? Surprisingly often, a student had also thought of the problems that a supervisor has pointed out.

Both a supervisor and a student have to be ready to think of various new solutions in the different phases of the process. Creativity and openness to perspectives or procedures are not ready immediately and change continuously during the process.

Supervising theses and studying mean constant learning and renewal as well as opening new doors. Often, new solutions are not found until one masters the traditional and recognized basic solutions rather than just being satisfied with them. 


\section{Proficiency}

\section{Acknowledging good work}

Writing a thesis is a challenging task. During the process, a student and supervisor learn to know each other as personalities with distinct characteristics and working methods. A student is willing to admit several limitations and improvement demands if he or she receives, along with criticism, also positive feedback and appreciation of the well-designed parts of thesis. It is important to realize this because the positive parts of a thesis may easily be ignored as if they were considered obvious. Yet there is hardly ever too much positive reinforcement and acknowledgement of mastery.

In addition to the positive tone and atmosphere of the interaction, the structure of a supervision conversation should be clear. Students appreciate a professional supervisor who follows the topics through in a structured way and interacts in a warm and emphatic manner.

It is also important that a student thanks her or his supervisor. If a student feels grateful for the supervisor's help, including the time spent on the thesis and consultation and useful remarks provided by the supervisor, it would be good for the student to show this gratitude. The major reward is mutual thanking not only verbally but also in a way that both the student and supervisor feel like they are appreciated. This does not guarantee the completion of a thesis but allows both parties to cherish the special relationship between the supervisor and the student.

\section{The supervision of writing}

It is important to emphasize writing when supervising a thesis. One learns to be a good writer by writing - that is the only way. And writing is the only way of reporting about one's research.

Often, an adequate advice for a student is the reassurance on how the text is always introductory at the beginning. Hardly anyone is capable of producing a complete text at one sitting; the finished text results from several rewritings. If one has a fear of a white paper, one might want to try to ease it by talking about one's thoughts to oneself, recording it, and writing it down.

The phases and solutions related to the progress of the research have to be explained when writing. It is important that a supervisor takes a reader's role and estimates whether the text is understandable to outsiders.

The point of the scientific writing is to prevent the text being open to various interpretations, but one should not overestimate a reader's ability to read between the lines either. After several modifications and choices, a writer might consider some things obvious and fails to write these matters. In addition, it is important to introduce the research phases logically for a reader. Thus, the interconnectedness of writing and thinking should not be underestimated. Brian Paltridge and Sue Starfield (2008, p. 47) remark this connection felicitously when pointing out how thinking clarifies writing ('How could I know what I am thinking before 
I see what I write'?) and how writing clarifies thinking ('How could I improve my writing before clarifying my thinking??).

Practicing of writing skills never ends: one can always develop and train oneself with others' feedback. There are plentiful guides to write a master's or PhD thesis (e.g., Bolker, 1998; Booth, Colomb, \& Williams, 2003; Bui, 2014; Clark \& Ivanic, 1997; Murray \& Moore, 2006; Paltridge \& Starfield, 2008; Vehviläinen, 2001; White, 2011).

\section{Actions}

A researcher might set too high a pressure for him or her. The demands and expectations set on a thesis may seem overwhelming. A supervisor might come up against mystified and unrealistic views that exaggerate the magnitude of the work. A supervisor has a special responsibility in the supervision of theses. The supervisor has to consider the progress of a student's work in light of the criteria set by the academic society. Sometimes there seems to be a need to emphasize that a thesis is not made for a supervisor, and a supervisor cannot bend the rules concerning the problems that might occur during research. The quality of a thesis is not determined by the supervisor's personal criteria, but the thesis has to meet the external criteria set by the academic society outside the university.

A student has to be able to trust on a supervisor's opinions when assessing the quality of a thesis. Even when a thesis seems to be ready in a student's opinion, a supervisor should point out both the strengths and critical parts of the work. However, it is good to remind a student of the work being never finished: there will be always something to improve. Knowing that after graduation there will be new chances to research and write, might help making the decision about finishing the work.

\section{Protective and supportive factors}

As Figure 3.2 showed, cloudberries have side leaves that protect and support the fruit to develop and flourish. The leaves are not drawn in the picture by accident but have a special role in the illustration of the supervision of theses. Certain factors shape the elements of supervision, which can be seen as these protective leaves (see Figure 3.3).

First, the curricula of master's or PhD studies form the basic guidelines of what is expected from students and to guarantee that they include all necessary studies and courses in their degrees so that they can develop as researchers. Fundamentally, the curriculum provides means to enhance will, proficiency, knowledge, and actions by offering a clear presentation of the study requirements in a degree. The curriculum is also a tool for the supervisor.

In addition, it is good to remember that the study process does not only consist of the supervisor and the student but that it happens in a wider communication with the academic community. Research seminars held by the supervisor function as safe and encouraging places to discuss and introduce one's research to 


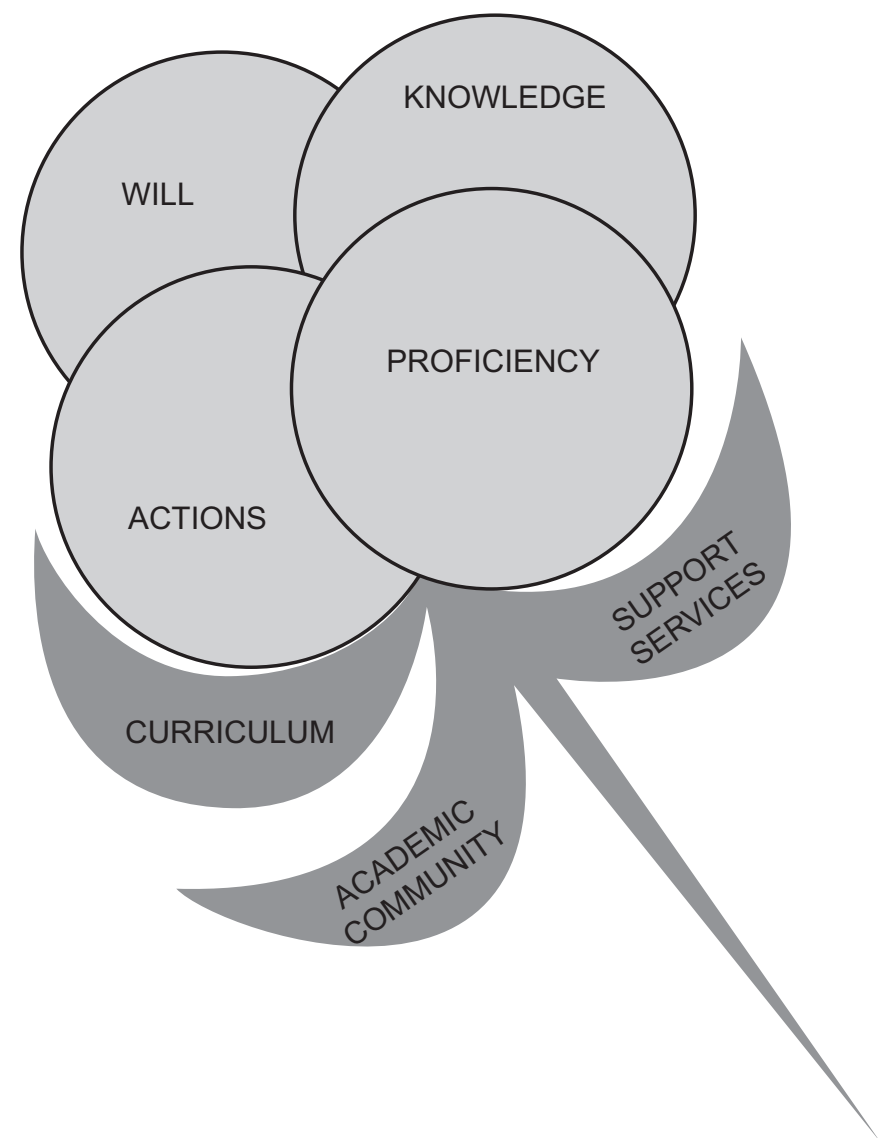

Figure 3.3 The supportive and protective factors of supervision (adopted from Määttä \& Uusiautti, 2016, p. 188)

other students. This also provides a good foundation to attend conferences and seminars worldwide and to participate in scientific discourse with other researchers. At its best, the academic community enhances science by providing insightful criticism, innovative ideas and comments, and collegial support.

Finally, the university offers many kinds of support to students. The university services cover, for example, library services, information technology, and methodological guidance. These form the necessary practical support that is crucial for successful study processes.

\section{Caring supervision}

Supervision of theses takes the supervisor to his or her limits. A supervisor's work contribution is different with every student. Although there is not any universal 
and complete formula or model to supervise, many above-mentioned pedagogical principles are important. Evidently, supervision also means the supervisor's self-reflection, testing of his or her limits, and being able to change even supervising methods that he or she has previously found good.

A caring supervisor has to constantly evaluate what he or she is capable of as a supervisor, how to inspire the student to toil and persevere, and to marvel their own abilities (Määttä, 2015). A committed supervisor can find the work the most satisfying and self-fulfilling when realizing the core of supervision relationship. Supervision of theses fulfills the core features of meaningful and appropriately challenging work, allowing plenty of opportunities to develop personally and professionally (e.g., Flint, Kurumada, Fisher, \& Zisook, 2011; Uusiautti \& Määttä, 2011).

To conclude, caring supervision can help address the challenges and opportunities the work entails today and in the future. Good supervision pays attention to the supervisor's strengths and weaknesses and those of the student as well. How similar are their cloudberries, or how well do they complement each other? Are all the covering leaves positively present and well used? Certainly, supervision practices will get new forms all the time, but the core is still the interaction between the supervisor and student, without forgetting the outer factors that contribute to the supervision relationship as described in this chapter. The illustration introduced in this chapter aspires to help analyzing the supervision practices and relationships and provide supervisors with concepts to reflect on the emphases in their own way of supervising. The supervisor should ask her- or himself, 'What elements are my strong areas as a supervisor, and which ones need a little development'? The point is also to show that there are many ways of being a good supervisor and that various supervision relationships require different levels of will, action, knowledge, and proficiency. Self-reflection and flexibility are features that help supervisors revise their supervision practices and develop as supervisors toward holistic, caring supervision that aims at quality outcomes without risking student's or supervisor's well-being.

\subsection{Teacher collaboration and well-being as the success factor}

\section{Well-being in university teachers' work}

Caring university teachers care about themselves, too. How can well-being and a sense of meaningfulness be enhanced in university teachers and professors? As suggested earlier in this chapter, one of the key elements of students' success is the well-being of teachers. If they achieve a level of positive engagement in their work (see e.g., Stairs \& Galpin, 2013), this attitude is likely to spread in students and elsewhere in the organization, too.

\section{Finding flow}

If we return the concept of caring teacherhood and love as one key element of it, we can also discuss well-being from this point of view. High-grade capability 
as a teacher requires daring, perseverance, and boldness to create one's own special field of interest. The courage to act according to one's own talents and be different from others, the ability to put off temporal impulses, and the ability to practice self-discipline are prerequisites of love and action that focus on higher mental values (Kerr, 1985; Uusikylä, 2008).

Skillful teachers know that remarkable scientific and artistic values are impossible to achieve without intensive concentration (Määttä, 2012). Phrasing one's own thoughts, refining one's special aptitudes, and building a strong identity necessitate the ability to withdraw from others' company and the possibility to examine and be engrossed. The masters in practical fields seem to differ from others in their ability to follow strict training programs with enthusiasm and persistently for years (Csikszentmihalyi, Rathunde, \& Whalen, 1996). This determination originates in emotional characteristics, says Daniel Goleman (1999, p. 109) and thus highlights the power of love in directing activeness and vigorwhich are also connected with the experience of flow.

At its magnificence, love appears as a so-called flow experience in many people's expertise and skillful doing. Mihaly Csikszentmihalyi (1990, 2000) has launched the concept that refers to an optimal or autotelic experience in which people are riveted so comprehensively by a challenging performance that their awareness of time and place blurs. Flow is possible when the challenges in a task are balanced with an actor's abilities. Flow is an enjoyable state of concentration and task orientation, leading to optimal performance, whether the case is wall creeping, chess playing, dancing, surgery, studying languages, painting, or composing music.

Flow can be achieved when one is able to act to the maximum of one's skills and at a suitable challenging level (Csikszentmihalyi, 2000), which is quite similar to Augustine's notion of moments of the soul's attentiveness (see Fitzgerald, 1999). The exact experience of flow and the active sense of well-being resulting from the former encourage people to develop and improve their skills. People are willing to strive for flow whether it is about love for math, art, programming, orthopaedics - or teaching (Csikszentmihalyi, 2000).

\section{Accepting challenges}

Teaching can be defined as active stimulus to positive experiences of success and remarkable achievement and as a self-centred oasis of positive emotions. However, a university teacher's work is interpersonal and relational, with a teacher's own personality fundamental to building relationships with students. A teacher's work involves plenty of emotional strain. In addition, a teacher inevitably has to experience frustration in his or her work. There are many situations when a teacher will feel like she or he has failed regardless of the solution he or she creates.

In the mix of multiple demands, a skillful teacher can prioritize the demands of his or her work. A teacher's engagement and drive are enhanced by the simple capacity to be happy about even the smallest achievements and by belief in a student's ability and desire to work hard within a variety of learning experiences. 
However, teachers have to realize that their own coping, motivation, and engagement require attention; they are not automatic.

\section{Having belief}

Teachers have to believe in their work and endeavor to build a nurturing environment and a more humane world. At their best, teachers help students to experience their own potentiality and see what life can offer and thus perceive their own work meaningful, inspiring, and motivating. Otherwise, teaching and learning may remain 'as a form of effective management of learning and become a means only because it is presumed to offer a link between the intentionality of curriculum designers and the actual learning outcomes which are developed in learners' (Webster, 2009, p. 44).

Actually, Lopez, Teramoto Pedrotti, and Snyder (2015) have presented a positive psychological school model in which hope is one of the key terms. This kind of hope and belief is argued to be connected with teachers' genuine wish to influence, care, and inspire students, and thus empower them. Whereas negative teachers damage students' learning processes and success, positive teachers spread enthusiasm and joy of education (see also Äärelä, Määttä, \& Uusiautti, 2016).

\section{Nurturing motivation}

Motivation can be considered the most salient factor in every theory attempting to predict and explain behavior and performance (Mitchell, 1997). Similarly, motivation can be explained by several various factors: especially the contextual matters have been on focus (Latham \& Pinder, 2005).

Actually, it is easy to name many different and obvious reasons why people work in the first place: to earn a living, it activates and stimulates, it provides social contacts, and it is rewarding (Uusiautti, 2015). Teachers especially have to be enthusiastic about their areas of expertise 'because they are models of enthusiasm for their students' (Lopez, Teramoto Pedrotti, \& Snyder, 2015, p. 420). Intrinsic motivation (Ryan \& Deci, 2000) refers to an individual's need for learning new skills and developing towards greater sovereignty, autonomy, and capacity. It comprises the individual's personality structure and motivation. The extrinsic control, rewards, or punishments are not significant to an intrinsically motivated employee: working is self-purposeful.

When an employee has high levels of motivation at work, he or she has the wish to perform well and work hard. Furthermore, motivated employees want to develop in their work; in other words, they want to increase their competence (Uusiautti \& Määttä, 2015b). Professional competence refers to an individual's subjective perception of his or her possibilities and abilities to act according to the goals and facility to affect his or her environment (Paloste, Uusiautti, \& Määttä, 2011). Furthermore, professional competence means how well tasks are performed and organized and how they are developed in order to achieve the goal (Evers, Rush, \& Berdrow, 1998). Professional competence consists of 
the ability to integrate information and learned skills into practice according to expectations. Professional competence also manifests an individual's attitude and behavior in certain work situations (Peluchette \& Jeanquart, 2000; Uusiautti, 2015 ). Competence is always competence to do something. It is seen as an inevitable prerequisite for successful or at least satisfactory professional performance (Munch \& Jakobsen, 2005).

\section{Positive social relationships and collaboration in university teachers' work}

Social relationships make an important part of positive activity at work (Uusiautti, 2016a, 2016b). Yet in universities, competition over results, research funding, and publications sometimes hinders open interaction and genuine collaboration in units (Uusiautti, Syväjärvi, Stenvall, Perttula, \& Määttä, 2012). It is important to notice the advantages of social support at work not only from an individual employee's perspective but also in the wider picture, including the success of the university. Shawn Achor (2010) has noted that social support is the greatest asset when it comes to achievement of success, and this conclusion is frequently supported by various organizational studies (e.g., Löfström \& Eisenschmidt, 2009).

Social support includes all employees, including the leaders, at universities. If the atmosphere at work is motivating, work roles are clear, work tasks are challenging, and leadership practices are supportive, a work environment where people are willing to help the university to achieve its goals can occur (Winter \& Sarros, 2002). A good and supportive atmosphere makes work meaningful and inspiring. For example, Finnish top workers (Uusiautti, 2008; see also Uusiautti \& Määttä, 2015b) emphasized the significance of working together and appreciated good atmosphere at work as important factors in their career development and positive work-related experiences - regardless of their occupation. On the other hand, it is clear that there is no work that always includes pleasant and joyful teamwork. Every workplace faces conflicts because people are different and perceive situations and issues at work in diverging ways, and this concerns universities, too.

Certain elements can be distinguished as the means to enhance positive relationships and collaboration in workplaces (Uusiautti, 2016a): collaboration and good atmosphere at work; clear rules in work units; encouragement, rewards, and feedback; and successes, daring, and development.

Positive atmosphere (e.g., helping, spurring, supporting) can significantly enhance employees' personal success at work and the likelihood of achieving goals. Similarly, those in leadership positions have reported that a negative atmosphere in the work unit can efficiently inhibit success and increase negative interaction and feelings, such as jealousy. Therefore, willingness to help each other in the unit becomes weaker, too, and the synergy of teamwork is lost. Concrete actions that enhance positive interaction and support can become the key when looking for the source of positive atmosphere. 
If we think about positive collaboration in universities, certain behavioral rules or guidelines that lead to positive interaction and atmosphere should be so obvious that everyone knows and follows them. But that is not the case in real life, and competition and jealousy often make teachers, researchers, and professors place friendliness and openness in the backseat.

And yet positive acts should happen always, not just when conflicts occur or changes are coming in the workplace. It is relevant to develop various positive acts that everyone could try in practice easily and without pressure. These acts should aim at increase in well-being, positive atmosphere, cooperation, and qualitative and measurable success at work.

Positive interaction, collaboration, and helping at their best provide work drive, positive experiences at work, and energy, even during times that employees feel they cannot, will not, and do not want to do anything. These moments of lack of enthusiasm and feelings of overwhelming pressures and hurry are probably part of any person's work. Work satisfaction and well-being are a sum of many factors, all the way from the fulfillment of physiological and mental basic needs and need for security to the needs of belonging, appreciation, and self-fulfillment (Rauramo, 2009). Positive relationships at work are part of many the aforementioned levels of well-being at work. According to Rauramo (2009), good social relationships are especially connected with everyone's need for belonging and becoming a member of the work community. But in a wider sense, open interaction, good manners, and respect towards others and selfrespect contribute to the need for appreciation and self-fulfillment (see also Onnismaa, 2010).

The following guidelines for positive acts to enhance collaboration at workplaces emerged from Uusiautti's (2015; see also 2016a, 2016b) research when she studied success in workplaces and leaders' and employees' perceptions and experiences of it.

\section{(1) Help}

Always help your team member when possible. Helping others does not take anything away from you but does provide you with a good mood when you notice that you were able to help, and you will get help when you need it. Collaboration has synergy because no one can know or do everything. Your co-worker's success contributes to the success of your team and your employer - and therefore, his or her success is your success, as well.

\section{(2) Compliment}

Always give positive feedback to one or more team members (whether he or she was your colleague, supervisor, or follower) when possible but at least once a day. Compliment yourself, too: acknowledge your successes and remember that it is okay to be proud of your successes and draw joy from them. This is how you learn 
about your strengths and boost your sense of competence and intrinsic motivation at work.

\section{(3) Thank}

Thank when you receive help or positive and constructive feedback. By showing your gratitude, you also show that you respect the other person, and this will enhance positive atmosphere and openness in your work team.

\section{(4) Dare}

Dare to critically analyze your own attitude at work. Dare to see challenges and changes as opportunities to develop. Dare to recognize your strengths and weaknesses. Courage is needed in the changing work, and its importance should not be ignored; courage is also a sign of hopefulness. In addition, positive acts can enhance positive engagement at work (Stairs \& Galpin, 2013) because they help perceive work and oneself as a worker more positively. This also means that one is able to find and recognize one's signature strengths (see also Seligman, 2011) and use them more actively at work. Daring to look in the mirror does not mean, therefore, just looking for negative features, weaknesses, and lousy attitudes but also daring to search for the good in oneself. This is how one can create opportunities just with one's own attitude and proactive action that can lead to success at work (Uusiautti, 2015; Uusiautti \& Määttä, 2015a, 2015b).

\section{Flourishing teachers produce successful students}

In positive organizations, five core elements prevail. According to Cheung (2015), positive organizations have positive practices when it comes to management, people management, and developmental practices. Second, good relationships and positive team synergy typify relationship enhancement in such organizations. The third element refers to employees' strengths and flourishing individual attributes. The last two elements of positive organizations are dynamic leadership and emotional leadership. The former means leadership practices that aim to maximize positive energy in the workplace, and the latter covers efforts to keep up employees' physical and psychological well-being and positive emotions. Altogether, they form the word PRIDE, which describes well a workplace in which everyone feels satisfied and happy. However, what is the most important here is that the higher the positive organization index is, the better performance the organization has (Cheung, 2015).

At the university level, such positive organizational practices will lead increased levels of well-being in teachers, professors, researchers, and other personnel - and the students! Darling-Hammond and Youngs (2002) have discovered that teacher quality predicts well students' achievements. Happy teachers have happy students, and this kind of happiness can boost students' success in university studies the best. 


\section{Successful university teachers and teaching}

Why should professors, lecturers, and other university teachers make an effort in teaching, supervision, and tutoring? To conclude this part of the book, we will list some reasons why teaching, tutoring, and supervision are so important.

\section{(1) Responsibility over students}

University teachers cannot avoid or delegate their responsibility and obligation to provide information, support, and guidance to students about their progress, goals, and contents of studies. These promises are given in student manuals and guidebooks in each university, and these expectations have to be responded so that each and every student feels welcome in the university. Students have to be assured that they have made the right choice about their study program and their university. This is about humane responsibility, but it also is an academic responsibility.

Karjalainen (1996) considers indifference as the opposite of academic responsibility. Indifference means irresponsibility over the quality of teaching or disinterest about students' learning.

\section{(2) Commitment to the university and its task and funding}

University personnel have to engage in activities that are defined by the funding the university receives. This means that teachers and other staff have to do the work they are paid for. Education is the greatest source of the basic funding in Finnish universities; therefore, the number of graduations determines the funding to a great extent - in addition to research work, of course. To reach numeric goals of graduations, teachers have to work actively to support students' study success and to make sure the existence of the university.

\section{(3) Rewarding work}

The most far-reaching and rewarding part of teaching, tutoring, and supervision is to get students interested in and seize the topical questions in their scientific fields so they can work for the continuity and progress of science. When teachers support and strengthen their learning and trust in their development and skills, motivation, and progress, students can achieve top performance that they might not have been able to achieve without the teachers' dedication to give positive feedback and encouragement. Teachers who invest in their teaching and supervision get the greatest joy from students' successes and achievements. With their support, students may start trusting in themselves as members of the academic community and as learners and recognize talents and abilities in them. This kind of positive self-image and belief makes them work hard for good study results and graduation. These goals require hard work but also teachers and students who have high levels of well-being.

(4) Teachers as bellwethers

University teachers can become valuable and important models and examples for students. Their positive teaching and supervising styles can show a direction to their lives by encouraging them to find goals for studies and even life in general. 
(5) The power of encouragement

Even the smallest words and gestures can help students to reach great results. Moreover, honest, small stories of teachers' own experiences at the university can assure students that they are members of the academic community. The philosophy of service is important (Karjalainen, 1996): if teachers find sincere willingness to help students, they just might learn new lessons about life and relationships. The ability to encourage others can become a mirror that also strengthens teachers themselves and shows them how to enjoy the sense of being able to guide, supervise, and teach.

(6) Valuable part of academic work

Good teaching and guidance are central and valuable parts of academic work. Similar to research skills, teaching and supervision as well as tutoring skills can be learned, developed, and shared colloquially in the university.

Caring for student is the prerequisite of universities' existence.

\section{References}

Äärelä, T., Määttä, K., \& Uusiautti, S. (2016). Caring teachers' ten dos. 'For the teacher, they might be just small things, but for the student, they mean the world'. International Forum of Teaching and Studies, 12(1), 10-20.

Achor, S. (2010). The happiness advantage: The seven principles of positive psychology that fuel successes and performance at work. New York, NY: Crown Business.

Alaoutinen, S., Bruce, T., Kuisma, M., Laihanen, E., Nurkka, A., Riekko, K., Tervonen, A., Virkki-Hatakka, T., Kotivirta, S., \& Muukkonen, J. (2009). LUT:n opettajan laatuopas [Quality manual for teachers in Lappeenranta University of Technology]. Lappeenranta: Lappeenranta University of Technology. Retrieved from www.lut.fi/fi/lut/introduction/quality/qualitybook/Documents/Opettajan_Laatuopas_B5_final.pdf

Anderson, E. C. (2005). Strengths-based educating: A concrete way to bring out the best in students - and yourself: The confessions of an educator who got it right finally! Educational Horizons, 83(3), 180-189.

Aragon, S. R. (2003). Creating social presence in online environments. In S. R. Aragon (Ed.), New directions for adult and continuing education (pp. 57-68). San Francisco, CA: Wiley Periodicals.

Atjonen, P. (2007). Educational technology and technology education for a better private and public life - Principles and practices from the Finnish viewpoint. In R. Jakku-Sihvonen \& H. Niemi (Eds.), Education as a societal contributor (pp. 91-110). Frankfurt am Main: Peter Lang.

Barnett, R. (2009). Knowing and becoming in the higher education curriculum. Studies in Higher Education, 34(4), 429-440. doi:10.1080/03075070902771978

Barnett, R., \& Coate, K. (2005). Engaging the curriculum in higher education. Maidenhead: Open University Press.

Best, B., \& Thomas, W. (2008). The creative teachinge learning resource book. New York, NY: Continuum International Publishing Group. 
Biggs, J., \& Tang, C. (2011). Teaching for quality learning at university: What the student does (4th ed.) Maidenhead: Society for Research into Higher Education \& Open University Press.

Bloom, B. S., Engelhart, M. D., Furst, E. J., Hill, W. H., \& Krathwohl, D. R. (1956). Taxonomy of educational objectives: The classification of educational goals. Handbook I: Cognitive domain. New York, NY: David McKay Company.

Bolker, J. (1998). Writing your dissertation on fifteen minutes a day: A guide for starting, revising and finishing your doctoral thesis. New York, NY: Henry Holt.

Booth, W. C., Colomb, G. G., \& Williams, J. M. (2003). A craft to research. Chicago, IL: University of Chicago Press.

Bosch, T. (2009). Using online social networking for teaching and learning: Facebook use at the University of Cape Town. South African Journal for Communication Theory and Research, 35(2), 185-200. doi:10.1080/02500160903250648

Boud, D., \& Lee, A. (Eds.) (2009). Changing practices of doctoral education. London: Routledge.

Bouhnik, D., \& Marcus, T. (2006). Interaction in distance-learning courses. Journal of the American Society for Information Science and Technology, 57(3), 299-305. doi:10.1002/asi.20277

Bui, Y. N. (2014). How to write a master's thesis? Los Angeles, CA: Sage.

Burns, T., \& Sinfield, S. (2004). Teaching, learning, and study skills: A guide for tutors. London: Sage.

Caldwell, C., \& Dixon, R. D. (2010). Love, forgiveness, and trust: Critical values of the modern leader. Journal of Business Ethics, 93, 91-101. doi:10.1007/ s10551-009-0184-z

Carman, T. J. (2005). Strength-based teaching: The affective teacher, no child left behind. Oxford: ScarecrowEducation.

Carver, C. S., \& Scheier, M. F. (2002). Optimism. In C. R. Snyder \& S. J. Lopez (Eds.), Handbook of positive psychology (pp. 231-243). Oxford: Oxford University Press.

Cheung, R. K. H. (2015). Positive workplaces in Hong Kong: Building positive organizations, engaging the heart of employees. In S. J. Lopez, J. T. Pedrotti, \& C. R. Snyder (Eds.), Positive psychology: The scientific and practical explorations of human strengths (pp. 450-453). Thousand Oaks, CA: Sage.

Clark, E., \& Ivanic, R. (1997). The politics of writing. London: Routledge.

Cruce, T., Wolniak, G. C., Seifert, T. A., \& Pascarella, E. T. (2006). Impacts of good practices on cognitive development, learning orientations, and graduate degree plans during the first year of college. Journal of College Student Development, 47(4), $365-383$.

Cryer, R. (2003). The research student's guide to success. Maidenhead: Open University Press.

Csikszentmihalyi, M. (1990). Flow: The psychology of optimal experience. New York, NY: Harper and Row.

Csikszentmihalyi, M. (2000). Beyond boredom and anxiety: Experiencing flow in work and play. San Francisco, CA: Jossey-Bass Publishers.

Csikszentmihalyi, M., Rathunde, K., \& Whalen, S. (1996). Talented teenagers: The roots of success and failure. Cambridge: Cambridge University Press.

Cullen, D., Pearson, M., Saha, L. J., \& Spear, R. H. (1994). Establishing effective Phd supervision. Canberra: Australian Government Publishing Service. 
Darling-Hammond, L. (2003). Keeping good teachers: Why it matters, what leaders can do. Educational Leadership, 60(8), 6-13.

Darling-Hammond, L., \& Youngs, P. (2002). Defining highly-qualified teachers: What does scientifically based research tell us? Educational Researcher, 31(9), 13-25.

Davis, B. G. (1993). Tools for teaching. San Francisco, CA: Jossey-Bass Publishers.

Delamont, S., Atkinson, P., \& Parry, O. (2000). Supervising the PhD: A guide to success. Baltimore, MD: Open University Press.

Dunleavy, P. (2003). Authoring a PhD: How to plan, draft, write and finish a doctoral thesis or dissertation. Hampshire: Palgrave.

Elliott, E. M, Isaacs, M. L., \& Chugani, C. D. (2010). Promoting self-efficacy in early career teachers: A principal's guide for differentiated mentoring and supervision. Florida Journal of Educational Administration \& Policy, 4(1), 131-146.

Evans, T., \& Kamler, B. (2005). The need for counter-scrutiny: Taking a broad view of doctoral education research. Higher Education Research and Development, 24(2), 115-118. doi:10.1080/07294360500062805

Evers, F. T., Rush, J. C., \& Berdrow, I. (1998). The bases of competence: Skills for lifelong learning and employability. San Francisco, CA: Jossey-Bass.

Fairholm, M. R., \& Fairholm, (2000). Leadership amid the constraints of trust. Leadership \& Organization Development Journal, 21(1/2), 102-109.

Feiman-Nemser, S. (2003). What new teachers need to learn. Educational Leadership, $60(8), 25-29$.

Field, B., \& Field, T. (1994). Teachers as mentors: A practical guide. Washington, DC: The Falmer Press.

Fischer, A. H., \& van Kleef, G. A. (2010). Where have all the people gone? A plea for including social interaction in emotion research. Emotion Review, 2(3), 208-211. doi:10.1177/1754073910361980

Fitzgerald, A. D. (1999). Augustine through the ages: An encyclopedia. Grand Rapids, MI: William B. Eerdmans Publishing Company.

Flint, A. S., Kurumada, K. S., Fisher, T., \& Zisook, K. (2011). Creating the perfect storm in professional development: The experiences of two American teachers and a university research team. Professional Development in Education, 37(1), 95-109. doi:10.1080/19415250903425502.

Freire, P. (1997). Pedagogy of the heart. New York, NY: Continuum.

Fromm, E. (1956). The art of loving. New York, NY: Harper Collins.

Gardner, S. (2007). 'I heard it through the grapevine': Doctoral student socialization in chemistry and history. Higher Education, 54, 723-740.

Golde, C. M. (2007). Signature pedagogies in doctoral education: Are they adaptable for the preparation of education researches. Educational Researcher, 36(6), 344-351. doi:10.3102/0013189X07308301.

Goleman, D. (1999). Tunneäly: Lahjakkuuden koko kuva [Emotional intelligence: The overall picture of talent] (J. Kankaanpää, Trans.). Helsinki, Finland: Otava.

Goleman, D. (2006). The socially intelligent. Educational Leadership, 64(1), 76-81.

Greenwald, R., Hedges, L. V., \& Laine, R. D. (1996). The effect of school resources on student achievement. Review of Educational Research, 66(3), 361-396.

Haapaniemi, T., Voutilainen, U., \& Ikäheimonen, K. (2001). Millä eväillä ohjauskokeiluihin? [With what provisions to mentoring experiments?] In U. Voutilainen \& 
T. Haapaniemi (Eds.), Ohjaus - opiskelun voimavara [Mentoring - a resource for studying] (pp. 97-112). Kuopio: University of Kuopio.

Hansen, K. (2009). Strategies for developing effective teaching skills in the affective domain Journal for Physical and Sport Education, 23(1), 14-19.

He, Y. (2009). Strength-based mentoring in pre-service teacher education: A literature review. Mentoring \& Tutoring: Partnership in Learning, 17(3), 263-275. doi:10.1080/13611260903050205

Hoyle, J. R. (2002). Leadership and the force of love: Six keys to motivating with love. Thousand Oaks, CA: Sage.

Hyppönen, O., \& Lindén, S. (2009). Opettajan küsikirja-opintojaksojen rakenteet, opetusmenetelmät ja arviointi [The teacher's manual - the constructs of study periods, teaching methods and evaluation]. Espoo: Teknillinen Korkeakoulu.

Jakku-Sihvonen, R. (2005). Kasvatustieteiden opetus ja asiantuntijan arkipätevyys [Education of the educational sciences and expert's everyday competence]. In R. Jakku-Sihvonen (Ed.), Uudenlaisia maistereita: Kasvatusalan koulutuksen kehittämislinjoja [New kinds of masters: Developmental guidelines of education of the educational sciences] (pp. 125-150). Jyväskylä, Finland: PS-Kustannus.

Jakku-Sihvonen, R., Tissari, V., Ots, A., \& Uusiautti, S. (2012). Teacher education curricula after the Bologna Process - a comparative analysis of written curricula in Finland and Estonia. Scandinavian Journal of Educational Research, 56(3), 261275. doi:10.1080/00313831.2011.581687

Karjalainen, A. (1996). Pieni tutoropas yliopisto-opettajille [A little tutoring manual for university teachers]. Oulu: University of Oulu.

Kearsly, G. (2000). Online education: Learning and teaching in cyberspace. Belmont, CA: Wadsworth.

Kerr, B. A. (1985). Smart girls, gifted women. Columbus, OH: Ohio Psychology Publishing Co.

Kezar, A. J., \& Kinzie, J. L. (2006). Examining the ways institutions create student engagement: The role of mission. Journal of College Student Development, 47(2), 149-172. doi:10.1353/csd.2006.0018

Klein, P. (1999). Reopening inquiry into cognitive processes in writing to learn. Educational Psychology Review, $11(3), 203-270$.

Knight, C. C. (2005). An educational process for developing student postgraduate mastery research: Theory and its application. International Journal of Teaching and Learning in Higher Education, 17, 69-74.

Korthagen, F. A. J. (2004). In search of the essence of a good teacher: Towards a more holistic approach in teacher education. Teaching and Teacher Education, 20(1), 77-97.

Koshik, I. (2002). A conversation analytic study of yes/no questions which convey reversed polarity assertions. Journal of Pragmatics, 34(12), 1851-1877.

Kuh, G. (2003, March/April). What we're students: Benchmarks for effective educational practices. Change, 24-32.

Kumar, S. (2003). An innovative method to enhance interaction during lecture sessions. Advances in Physiology Education, 27(1), 20-25. doi:10.1152/advan.00043.2001

Lähteenoja, S. (2010). Uusien opiskelijoiden integroituminen yliopistoon - Sosiaalipsykologinen näkökulma [The ingration of new students in university - a socialpsychological viewpoint]. Helsinki: University of Helsinki. Retrieved from http:// urn.fi/URN:ISBN:978-952-10-6086-1. 
Laitinen, K., Pekonen, E., \& Pirttimäki, S. (2009). Hopskäytäntöjen nykytilanne hopsohjaajien näkemyksiä tutkintoundistuksen tavoitteiden toteutumisesta [The current situation of personal study planning practices - personal study planning supervisors' perceptions of the achievement of goals of degree reform]. Kuopio: University of Kuopio.

Lancaster, O. E. (1974). Effective teaching and learning. New York, NY: Gordon and Breach.

Latham, G. P., \& Pinder, C. C. (2005). Work motivation theory and research at the dawn of the twenty-first century. Annual Review of Psychology, 56, 485-516. doi:10.1146/annurev.psych.55.090902.142105

Lea, M., \& Street, B. (2000). Student writing and staff feedback in higher education: An academic literacy's approach. In M. Lea \& B. Stieres (Eds.), Student writing in higher education: New contexts (pp. 32-46). Buckingham: Society for Research in Higher Education.

Lehtinen, E., \& Jokinen, T. (1999). TUTOR - itsenäistypän oppijan ohjaajana [The tutor - as the guide for an independent learner] (3rd ed.). Jyväskylä: Atena Kustannus.

Liesveld, R., Miller, J. A., \& Robinson, J. (2005). Teach with your strengths: How great teachers inspire their students. New York: Gallup Press.

Lindblom-Ylänne, S. (2004). Raising students' awareness of their approaches to study. Innovations in Education and Teaching International, 41(4), 405-422. doi:10.1080/1470329042000277002

Lindblom-Ylänne, S., \& Nevgi, A. (Eds.). (2009). Yliopisto-opettajan küsikirja [A university teacher's manual]. Helsinki: WSOYpro.

Lindstrom, D. (2012). Editor's remarks: New literacies, teacher education, and thirdspace pedagogy. Journal of Digital Learning in Teacher Education, 28, 91. doi:10. 1080/21532974.2012.10784685

Linkins, M., Niemiec, R. M., Gillham, J., \& Mayerson, D. (2014). Through the lens of strength: A framework for educating the heart. The Journal of Positive Psychology: Special Issue in Memory of Chris Peterson, 10(1), 64-68. doi:10.1080/17439760. 2014.888581

Linley, A., Willars, J., \& Biswas-Diener, R. (2010). The strengths book: Be confident, be successful, and enjoy better relationships by realising the best of you. Coventry: CAPP Press.

Löfström, E., \& Eisenschmidt, E. (2009). Novice teachers' perspectives on mentoring: The case of the Estonian induction year. Teaching and Teacher Education, 25, 681-689.

Lopez, S. J., Teramoto Pedrotti, J., \& Snyder, C. R. (Eds.). (2015). Positive psychology: The scientific and practical explorations of human strengths. Thousand Oaks, CA: Sage.

Määttä, K. (2012). The pedagogy of supervising doctoral theses. In K. Määttä (Ed.), Obsessed with doctoral theses (pp. 143-160). Rotterdam: Sense Publishers.

Määttä, K. (2014). Opettajatuutori yliopisto-opintojen tukena [Teacher tutors supporting university studies]. Rovaniemi: Lapland University Press.

Määttä, K. (2015). A good supervisor - ten facts of caring supervision. International Education Studies, 8(9), 185-193. doi:10.5539/ies.v8n9p185.

Määttä, K., \& Uusiautti, S. (201la). How to enhance the smoothness of university students' study paths? International Journal of Research Studies in Education, 1(1), 47-60. doi:10.5861/ijrse.2012.vlil.16 
Määttä, K., \& Uusiautti, S. (2011b). Pedagogical love and good teacherhood. In Education, 17(2). Retrieved from http://ineducation.ca/article/ pedagogical-love-and-good-teacherhood

Määttä, K., \& Uusiautti, S. (2012). Pedagogical authority and pedagogical love connected or incompatible? International Journal of Whole Schooling, 8(1), 21-39.

Määttä, K., \& Uusiautti, S. (2016). The resources of good supervision. European Scientific Journal, April/2016/Special Edition, 180-191.

Määttä, K., Uusiautti, S., \& Määttä, M. (2014). Doctoral dissertation as action at one's own limits - What are the individual and context-bound strengths of top performance? International Journal of Arts \& Sciences, 7(6), 587-605.

Maddux, J. E. (2002). Self-efficacy: The power of believing you can. In C. R. Snyder \& S. J. Lopez (Eds.), Handbook of positive psychology (pp. 277-287). Oxford: Oxford University Press.

Mäkinen, J., Olkinuora, E., \& Lonka, K. (2004). Students at risk: Students' general study orientations and abandoning/prolonging the course of studies. Higher Education, 48(2), 173-188. doi:10.1023/B:HIGH.0000034312.79289.ab

Mäkinen, P. (2007). Opetusta, ohjausta vai tutorointia [Teaching, guidance, or tutoring]. In S. Nurmela, S., \& Suominen, R. (Eds.), Verkko-opettajaksi viikossa [Becoming an online-teacher in a week]. Turku: University of Turku.

Maor, D. (2003). The teacher's role in developing interaction and reflection in an online learning community. Education Media International, 40(1/2), 127-137. doi:10.1080/0952398032000092170

Marcos, J. M., Sanchez, E., \& Tillema, H. H. (2011). Promoting teacher reflection: What is said to be done. Journal of Education for Teaching, 37(1), 21-36.

Margolis, E. (2001). The hidden curriculum in higher education. New York, NY: Routledge.

Martin, C. (2004). From other to self: Learning as interactional change. Uppsala Studies in Education No. 107. Uppsala: Acta Universitatis Upsaliensis.

Mayya, S. S., \& Roff, S. (2004). Students' perceptions of educational environment. Education for Health, 17(3), 280-291. doi:10.1080/13576280400002445

Mitchell, T. R. (1997). Matching motivational strategies with organizational contexts. Research in Organizational Behavior, 19, 57-149.

Moitus, S., Huttu, K., Isohanni, I., Lerkkanen, J., Mielityinen, I., Talvi, U., UusiRauva, E., \& Vuorinen, R. (2001). Opintojen ohjauksen arviointi korkeakouluissa [Evaluation of study counceling in higher education]. Helsinki: Korkeakoulujen arviointineuvosto.

Mullins, G., \& Kiley, M. (2002). 'It's a phD, not a Nobel prize': How experienced examiners assess research theses. Studies in Higher Education, 28(49), 369-386. doi:10.1080/0307507022000011507.

Munch, B., \& Jakobsen, A. (2005). The concept of competence in engineering practice. Engineering and Product Design Education Conference, September 15-16, Napier University, Edinburgh.

Murray, R., \& Moore, S. (2006). The handbook of academic writing: A fresh approach. New York, NY: Open University Press.

Niemi, H., \& Multisilta, J. (Eds.). (2014). Rajaton luokkahuone [A limitless classroom]. Jyväskylä: PS-Kustannus.

Nummenmaa, A. R.. (2008). Henkilökohtainen ohjauskeskustelu [Personal supervision discussion]. In A. R. Nummenmaa, K. Pyhältö, \& T. Soini (Eds.), Hyvä 
tohtori! Tohtorikoulutuksen rakenteita ja prosesseja [Good doctor! Structures and processes of doctoral education] (pp. 73-83). Tampere: Tampere University Press

O'Connell, D. (2006). Brief literature review on strength-based teaching and counselling. Research and draft prepared for the Metropolitan Action Committee on Violence Against Women and Children (METRAC), Ontario. Retrieved from www.strengthsineducation.ca/uploads /2/2/0/0/22003628/strength.based.learning.lit.review.pdf

Onnismaa, J. (2010). Opettajien työhyvinvointi: Katsaus opettajien työhyvinvointitutkimuksiin 2004-2009 [Teachers' well-being at work: A review of teachers' wellbeing surveys in 2004-2009]. Helsinki: Finland's National Board of Education. Retrieved from www.oph.fi/download/124603_Opettajien_tyohyvinvointi.pdf

Pajares, F. (2001). Toward a positive psychology of academic motivation. The Journal of Educational Research, 95(1), 27-35.

Paloste, A., Uusiautti, S., \& Määttä, K. (2011). Through education and work experience toward professional competence - a phenomenographic study on some Finnish nurses' and midwives' perceptions. Journal of Studies in Education, 1(1), 1-21. doi:10.5296/jse.vlil.84l

Paltridge, B., \& Starfield, S. (2008). Thesis and dissertation writing in a second language: A handbook for supervisors. London: Routledge.

Parker, M. A., Ndoye, A., \& Imig, S. R. (2009). Keeping our teachers! Investigating mentoring practices to support and retain novice educators. Mentoring \& Tutoring: Partnership in Learning, 17(4), 329-341.

Parry, S. (2007). Disciplines and doctorates. Dordrecht: Springer.

Peluchette, J. V., \& Jeanquart, S. (2000). Professionals' use of different sources at various career stages: Implications for career success. Journal of Social Psychology, 140(5), 549-564.

Philips, M., \& Pugh, D. (2005). How to get a PhD: A handbook for students and their supervisors. Maidenhead: Open University Press.

Pimparyon, P., Roff, S., Mcaleer, S., Poonchai, B., \& Pemba, S. (2000). Educational environment, student approaches to learning and academic achievement in a Thai nursing school. Medical Teacher, 22, 359-364.

Popper, M., \& Amit, A. (2009). Attachment and leader's development via experiences. The Leadership Quarterly, 20(5), 749-763.

Prewitt, V. (2003). Leadership development for learning organizations. Leadership \& Organization Development Journal, 24(2), 58-61. doi:10.1108/01437730210463242

Quinlan, D., Swain, N., \& Vella-Brodrick, D. A. (2012). Character strengths interventions: Building on what we know for improved outcomes. Journal of Happiness Studies, 13(6), 1145-1163. doi:10.1007/s10902-011-9311-5

Rath, T. (2007). StrengthsFinder 2.0. New York, NY: Gallup Press.

Rauramo, P. (2009). Työhyvinvoinnin portaat - työkirja [The steps of well-being at work - a work book]. Helsinki: Työturvallisuuskeskus.

Rego, A., Ribeiro, N., Pina, M., \& Jesuino, J. C. (2011). How happiness mediates the organizational virtuousness and affective commitment relationship. Journal of Business Research, 64(5), 524-532.

Ryan, R. M., \& Deci, E. L. (2000). When rewards compete with nature: The undermining of intrinsic motivation and self-regulation. In C. Sansone \& J. M. Harackiewicz (Eds.), Intrinsic and extrinsic motivation: The search for optimal motivation and performance (pp. 14-54). Thousand Oaks, CA: Academic Press. 


\section{Successful university teachers and teaching}

Salmela, M., Uusiautti, S., \& Määttä, K. (2015). Finnish high-achieving students' perceptions of the best practices in teaching. International Journal of Education, 7(2), 126-145. doi:10.5296/ije.v7i2.7244

Säntti, J. (1999). Opiskelukyvyn jäljillä [Tracing the ability to study]. Helsinki: Otus. Retrieved from www.otus.fi/Otus_15_1999.pdf (Luettu: 30.5.2011).

Schreiner, L. A., \& Anderson, E. C. (2005). Strengths-based advising: A new lens for higher education. NACADA Journal, 25(2), 20-29. doi:10.12930/0271-9517-25.2.20

Schunk, D. H., \& Pajares, F. (2005). Competence perceptions and academic functioning. In A. J. Elliot \& C. S. Dweck (Eds.), Handbook of competence and motivation (pp. 85-104). New York, NY: The Guilford Press.

Seligman, M. E. P. (2002). Authentic happiness: Using the new positive psychology to realise your potential for lasting fulfillment. New York, NY: Free Press.

Seligman, M. E. P. (2011). Flourish: A new visionary understanding of happiness and well-being. New York, NY: FreePress.

Silius, K., Miilumäki, T., Huhtamäki, J., Tebest, T., Meriläinen, J., \& Pohjolainen, S. (2010). Students' motivations for social media enhanced studying and learning. Knowledge Management \& E-Learning: An International Journal, 2(1), 51-67.

Stacey, E. (2002). Social presence online: Networking learners at a distance. In D. M. Watson \& T. Downes (Eds.), Networking the learner (pp. 39-48). New York, NY: Springer Science+Business Media.

Stairs, M., \& Galpin, M. (2013). Positive engagement: From employee engagement to workplace happiness. In P. A. Linley, S. Harrington, \& N. Garcea (Eds.), The Oxford handbook of positive psychology and work (pp. 155-172). Oxford: Oxford University Press.

Swan, K. (2002). Building learning communities in online courses: The importance of interaction. Education, Communication \& Information, 2(1), 23-29. doi:10.1080/146363102200000501

Tallent-Runnels, M. K., Thomas, J. A., Lan, W. Y., Cooper, S., Ahern, T. C., Shaw, S. M., \& Liu, X. (2006). Teaching courses online: A review of the research. Review of Educational Research, 76(1), 93-135. doi:10.3102/00346543076001093

Taylor, S., \& Beasley, N. (2005). Handbook for doctoral supervisors. London: Routledge.

Theilheimer, R. (1991). Involving students in their own learning. Clearing House, 65(2), 123-126.

Tian, S. W., Yu, A. Y., Vogel, D., \& Kwok, R. C. W. (2011). The impact of online social networking on learning: A social integration perspective. International Journal of Networking and Virtual Organisations, 8(3/4), 264-280. doi:10.1504/ IJNVO.2011.039999

Uusiautti, S. (2008). 'Tänään teen elämäni parbaan työn'. Työmenestys Vuoden Työntekijöiden kertomana ['Today, I'll work better than ever'. Employees of the year describe their experiences of success at work.]. PhD Diss., University of Lapland, Rovaniemi, Finland.

Uusiautti, S. (2013). An action-oriented perspective on caring leadership: A qualitative study of higher education administrators' positive leadership experiences. International Journal of Leadership in Education: Theory and Practice, 16(4), 482-496. doi:10.1080/13603124.2013.770077

Uusiautti, S. (2015). Menestyvä ja hyvinvoiva yritys positiivisen psykologian valossa. Yritysjohdon ja työntekijöiden näkemyksiä menestyksestä [Successful and thriving 
enterprise in the light of positive psychology. Leaders' and employees' perceptions of success]. Helsinki: BoD.

Uusiautti, S. (2016a). How do positive acts influence success at work? A case study of enterprise leaders' and employees' perceptions of success. Organizational Cultures: An International Journal, 16(3), 13-21.

Uusiautti, S. (2016b). Success at work requires hope and the ability to engage in an optimistic attitude. European Journal of Workplace Innovation, 2(2).

Uusiautti, S., \& Määttä, K. (2013a). Enhancing university students' study success through caring leadership. European Scientific Journal, SE 2/2013, 398-407.

Uusiautti, S., \& Määttä, K. (2013b). How to train good teachers in Finnish universities? Student teachers' study process and teacher educators' role in it. European Journal of Educational Research, 1(4), 339-352.

Uusiautti, S., \& Määttä, K. (2014). I am no longer alone - how do university students perceive the possibilities of social media? International Journal of Adolescence and Youth, 19(3), 293-305. doi:10.1080/02673843.2014.919600

Uusiautti, S., \& Määttä, K. (2015a). Positive psychological viewpoints to successful leadership. In A. M. Columbus (Ed.), Advances in psychology research Vol. 101 (pp. 93-104). New York, NY: Nova Science Publishers.

Uusiautti, S., \& Määttä, K. (2015b). The psychology of becoming a successful worker: Research on the changing nature of achievement at work. New York, NY: Routledge.

Uusiautti, S., Syväjärvi, A., Stenvall, J., Perttula, J., \& Määttä, K. (2012). 'It's more like a growth process than a bunch of answers' University leaders describe themselves as leaders. Procedia - Social and Behavioral Sciences, 69, 828-837. doi:10.1016/j. sbspro.2012.12.005

Uusikylä, K. (2008). Naislahjakkuus [Female talent]. Jyväskylä: PS-Kustannus.

van Manen, M. (1991). The tact of teaching: The meaning of pedagogical thoughtfulness. London: Althouse Press.

van Manen, M., \& Li, S. (2002). The pathic principle of pedagogical language. Teaching and Teacher Education, 18, 215-224.

Vehviläinen, S. (2001). Ohjaus vuorovaikutuksena [Supervision as interaction]. Helsinki: Gaudeamus.

Wall, D., \& McAleer, S. (2000). Teaching the consult teachers: Identifying the core content. Medical Education, 34(2), 131-138.

Webster, R. S. (2009). Why educators should bring an end to pedagogy. Australian Journal of Teacher Education, 34(1), 42-53.

White, B. (2011). Mapping your thesis: The comprehensive manual of theory and techniques for masters and doctoral research. New York, NY: Barnes \& Noble.

White, K. W. (1999). The online teaching guide: A handbook of attitudes, strategies, and techniques for the virtual classroom. Needham Heights, MS: Allyn \& Bacon.

Winter, R., \& Sarros, J. (2002). The academic work environment in Australian universities: A motivating place to work? Higher Education Research and Development, $21(3), 241-258$.

Wood, A. M., Linley, P. A., Maltby, J., Kashdan, T. B., \& Hurling, R. (2011). Using personal and psychological strengths leads to increases in well-being over time: A longitudinal study and the development of the strengths use questionnaire. Personality and Individual Differences, 50(1), 15-19. doi:10.1016/j. paid.2010.08.004 
114 Successful university teachers and teaching

Yeager, J. M., Fisher, S. W., \& Shearon, D. N. (2011). Smart strengths: A parentteacher-coach guide to building character, resilience, and relationships in youth. New York, NY: Kravis Publishing.

Zombylas, N. (2007). Emotional ecology: The intersection of emotional knowledge and pedagogical content knowledge in teaching. Teaching and Teacher Education, 23(4), 355-367. doi:10.1016/j.tate.2006.12.002 


\section{Part 4}

\section{The importance and essence of study success}

In this part, we conclude the book by highlighting the key points that connect success and well-being in university studies. The first chapter explains the meaning of engagement and optimism: how they both are needed to persevere in studies and to reach the valuable achievement of graduation and how their emergence in students can be supported by the university community. The second chapter continues by discussing the meaning of love for learning and how this positive state or attitude to studies can become not only an important success factor but also enhance well-being. Eventually, the last chapter introduces the concept of study success as a two-dimensional phenomenon. On the one hand, success is about the outcomes - passing courses, high grades, and finally graduation - but on the other hand, and as the earlier parts of the book have showed, it is also about the study process.

\subsection{Success requires engagement and optimism}

\section{Back to the definition of success}

What is success? Who can define it? Nicki Baum's comparison between success and the North Pole does seem familiar to many of us who think about the nature of success: success can be thought as an outcome of self-centred behavior, a state of life filled with envy, cold-heartedness, and opportunism. Our viewpoint is based on positive psychology and interest in human strengths and flourishing. We define success tightly connected with self-fulfillment and well-being. In this chapter, we continue our analysis on success by discussing it the light of the concepts of engagement and hope.

Uusiautti (2013) defined success at work as the combination of three elements based on her research among awarded Finnish top workers, who were considered the examples of people having success at work (see Uusiautti, 2008; see also Uusiautti \& Määttä, 2015b). According to the definition, success at work depends on certain individual features. These include, among others, competence (e.g., Paulsson, Ivergård, \& Hunt, 2005; Schunk \& Pajares, 2005), motivation (Deci \& Ryan, 2008; Mitchell, 1997), and the ability to select positive strategies (Baltes \& Freund, 2006; Maddux, 2002). These are important features in 


\section{The importance and essence of study success}

students, too, but as workers, students are also surrounded by their special work context, the university. These context-bound features, such as opportunities and restrictions, expectations, and obligations, determine how the person's personal features match with the current conditions (see also Karasek \& Theorell, 1990). Individual features and context-bound factors form the fundamental conditions for success. Second, success requires positively focused proactivity: success does not happen without action (see also Achor, 2010). This kind of action consists of seizing opportunities, using one's strengths, and pursuing personal development (Linley, Willars, \& Biswas-Diener, 2010). The positive feeling about one's studies and positive emotions that studies produce are important. Finally, success is manifested as a sense of meaningful doing, productivity, and perceived well-being (see also Uusiautti \& Määttä, 2015a). Studies among Finnish top workers (see e.g., Uusiautti, 2008; Uusiautti \& Määttä, 2015b) confirmed that the positive experience of work is one of the most essential dimensions of success (see also Liden, Wayne, \& Sparrowe, 2000) - and this is something we will now discuss in the light of success in university studies.

\section{The role of hope and engagement in studies}

Success has something to do with the essential elements of well-being as, for example, defined by Prof. Martin Seligman (2011). Seligman defines well-being as a construct of certain elements that each contribute to the overall well-being. In his five-dimensional model of well-being, Seligman names positive emotions, engagement, relationships, meaning, and achievement as the core elements. Here, engagement means doing something with total concentration, at the limits of one's skills. From this perspective, engagement is connected with the concept of flow (see Csikszentmihalyi, 2008). On the other hand, engagement theories that define the reasons for doing something persistently are closely connected with theories about intrinsic motivation (see e.g., Latham \& Pinder, 2005). According to Schneider (2001), engagement can be seen, in addition to persistence, as flexibility and creative thinking, as well as higher subjective well-being. Regardless of achieving the sense of optimal doing when working alone or as a member of a team, opportunity uses one's strengths, and skills can play the leading role in engagement among students.

Similarly, the concept of achievement as an element of well-being is also interesting from the perspective of success in university studies: 'people pursue success, accomplishment, winning, achievement, and mastery for their own sakes' (Seligman, 2011, p. 18). The suggestion is that people tend to pursue success naturally, which is especially manifested when acting free of coercion. The connection with well-being is with what people do - or merely choose to do.

However, we argue that engaged action and achievements necessitate a certain kind of attitude as well, which resembles positivity, trust in one's abilities, and hopeful views about the world and one's place in it (see also Uusiautti, 2016a). Indeed, for example, optimism is one of the core concepts of positive psychology (Peterson, 2000) and affects how people pursue goals. If they believe their goals 
are achievable, they are optimistic (Carver \& Scheier, 2002). This is why the concept of optimism is often confused with hope. Gillham and Reivich (2004) explain that the difference between these two concepts is that whereas hope is often defined as a wish for something with some expectation that it will happen, optimism is typically defined as a tendency or disposition to expect the best. Thus, hope typically refers to expectations in a specific situation, but optimism refers to general expectations. Peterson and Luthans (2003) consider optimism a vital part of hope but emphasize that they still are distinctively separate concepts.

Optimism therefore determines how we experience events. Achor (2010) noted that 'By scanning our mental map for positive opportunities, and by rejecting the belief that every down in life leads us only further downward, we give ourselves the greatest power possible' (p. 109). This means that people have a habitual way of explaining events (Peterson, 2000; Peterson, Seligman, \& Vaillant, 1988). Furthermore, whereas optimism is shown to be connected to higher life satisfaction, health, perseverance, and resilience, pessimism has connection to depression (Reivich \& Gillham, 2003; Reivich, Gillham, Chaplin, \& Seligman, 2013).

Hope is often defined as a wish for something with some expectation that it will happen; it is an important human strength (Seligman, Steen, Park, \& Peterson, 2005). It is worth noticing that realistic, positive expectations closely relate to an expectation that one's behavior will be effective. When considering the phenomenon of success, hope is particularly important, especially in the light of achieving future goals and plans and how certain events during studies especially the negative ones - are experienced. Positive expectations can partly result from a hopeful attitude.

It has also been argued that the best results in life can be achieved with realistic optimism (see Schneider, 2001). Realistic optimism involves enhancing and focusing on the favorable aspects of our experiences. Consequently, Schneider (2001) includes the awareness of reality in optimism by stating that 'realistic optimism involves hoping, aspiring, and searching for positive experiences while acknowledging what we do not know and accepting what we cannot know' (p. 253). It is worth noticing that realistic, positive expectations closely relate to self-awareness and self-knowledge. When considering the phenomenon of success, realistic optimism may be particularly important because it can considerably predict the likelihood of achieving future goals and plans.

Snyder (2002) also defines the skills of self-motivation and reaching goals with the concept of hope. Snyder defines hope as a positive motivational state that is based on the interaction among goals, planned actions, and agency (see also Snyder, Irving, \& Anderson, 1991). Eventually, the most extraordinary characteristic among the most successful students might be their positive attitude and the hope they express. Successful students do not give up in the face of conflicts. Instead, they see such situations as opportunities to reassess their study skills and develop. Interestingly, this tendency manifests also engagement: they are persistent, and they have willpower. Furthermore, successful students see adversities as challenges that they expect they can solve - instead of hopeless dead ends. 


\section{The importance and essence of study success}

This kind of proactive attitude, willingness to strive for success, is at the very core of top students' characteristics and means that they have waypower, the other important element of hope in addition to willpower (Snyder, 2002). If one expects the best, one has the will. But if one is ready to work for it, one has the way, too.

\section{Success as positive, engaged strategies}

The analysis shows that although top performance or steady, quality performance can lead to success, it can also be seen as a more comprehensive process (Uusiautti \& Määttä, 2015b). Namely, people who want to develop and seize opportunities in life can be seen as following a positive strategy. Carver and Scheier (2005) have pointed out that it is also important that people realize when goals can be met and when it is time to give up. Ultimately, it is about the ability to estimate the situation and act accordingly. Likewise, future expectations greatly affect how people react to changes and challenges. An optimistic attitude plays a salient role (Carver \& Scheier, 2002); however, the strategy of success can also be described in other ways.

For example, Locke (2002) claims that success requires persistent trials. One has to think about what is a desirable goal and why, what kinds of intermediate goals should be set, how to reach the goal, how to prioritize demands that are contradictory in relation to the goal, and how to overcome future obstacles and setbacks. Baltes and Freund (2006; see also Freund \& Baltes, 1998) add that people's lives are filled with opportunities and limitations that can be mastered adaptively through selection, optimization, and compensation (Freund \& Baltes, 1998). At the core of selecting suitable goals, optimizing one's action, and compensating if necessary lies one's self-knowledge; the recognition of one's strengths and abilities. Indeed, for example, Covey (2006) considers success as a strategy in which knowledge, skills, and will are combined. Knowledge means that one knows what to do and why, but it is skills that can make it happen. Will here means motivation or the need to achieve something. As these three dimensions meet, a strategy leading to success can emerge.

Naturally, the constant pursuit of success can lead to an endless treadmill compared, for instance, with the pursuit of happiness (see Brickman, Coates, \& Janoff-Bulman, 1978; Diener, Lucas, \& Napa Scollon, 2006). As also Seligman's (2011) idea of achievement as a part of well-being pointed out, people constantly strive for something. Although happiness can be seen as a state that fades, success is understood as a way to fulfill one's skills, develop, and learn. Thus, it contributes to a human being's well-being. It can become what a positive spiral draws from but also nourishes hope and engagement.

\section{How to combine engagement and hope to reach success in university studies}

According to Snyder's (2002) hope theory, hope does not exist without a clear and compelling mental picture of a desirable goal and planning of various ways to 
reach the goal. From the perspective of success, hope seems to be a way to face positive and negative situations and events. Hope also includes a certain type of positive self-image as oneself as a student, which helps the student perceive adversities and difficulties as challenges and opportunities to develop.

Hopeful attitude is not, however, enough alone. Engagement in studies is also an important element of success. It is manifested in many levels of action. First, success requires persistence and readiness to work hard (Maslach \& Leiter, 1999). But to find toil pleasing, another type of engagement is also needed, the one resulting from being able to become one with the target (as described by Seligman, 2011). This means that it is equally important to find one's studies and the field one is studying suitable to oneself, an arena of using one's strengths and abilities widely (see also Uusiautti, 2015a).

To sum up, success is quite a multidimensional combination of engagement and hope at the level of action. First, it requires that one seizes challenges and dares to indulge in studies. Eventually, it is possible to see the potential in oneself. Second, success needs work. There are not any shortcuts to success. No one can avoid mistakes, difficulties, or boring tasks during studies, either. With an optimistic attitude, it is possible to find pleasure from accomplishing the most tedious parts of studies. Third, one has to have an optimistic attitude about oneself as well. Maddux (2002) has wisely said that 'This truth is that believing you can accomplish what you want to accomplish is one of the most important ingredients - perhaps the most important gradient - in the recipe for success' (p. 277). Maddux refers to self-efficacy, a sense of knowing one's skills and capability (see also Shepperd, Ouellette, \& Fernandez, 1996). And these are the important features we emphasized in Part 2 when referring to students' study experiences as well as in Part 3 when viewing ways university teachers can support students' flourishing.

Indeed, to adopt a successful study attitude, the role of supervisors and colleagues is great. But also, one's background factors, such as support provided by the childhood home (see e.g., Hyvärinen \& Uusiautti, 2014; Oberle, Schonert-Reichl, Guhn, Zumbo, \& Hertzman, 2014; Uusiautti \& Määttä, 2013), are worth studying. Indeed, education aims at enhancing students' well-being and success in life - in other words, helping children to find their place in society. It is crucial to discuss how education could support optimistic attitudes toward one's performing. Good practices and models should be introduced at every education level so that everyone can find their own strength areas and use them fully.

We have outlined here the role of hope as a part of success in university studies. Optimistic attitudes are at the core of hope, yet optimism can be viewed critically. It seems that realistic optimism is necessary for success. Actually, Sweeny, Carroll, and Shepperd (2006) have also noted that both optimism and shift from optimism are important to optimal development because they include a readiness to deal with setbacks and a readiness to take advantage of opportunities. Through self-knowledge and awareness of one's strengths, it is possible to use optimistic attitudes the best, which also influence one's engagement. Fundamentally, the relationship among success, engagement, and hope is quite reciprocal in nature (see also Xanthopoulou, Bakker, Demerouti, \& Schaufeli, 2009). 
The hope perspective provides a new understanding about success. Furthermore, the concept of hope is interesting here because it can explain students' abilities to survive in the riptide of the demanding university studies and balance their expectations and their own hopes and dreams about their future.

\subsection{Love for learning as the way toward well-being and success}

To provide a wider perspective to success, we want to discuss the role of love for learning in studies. Love of learning has been argued to be one of the main ingredients of engagement and true success in studies, too (Shugart, 2002). In Part 2, we analyzed various student-related factors that might contribute to success. It is true that if a lack of success is due to deficiencies in skills, it is easily 'curable' because the means of teaching academic skills are well-known. Igniting love for learning in students is a much more demanding task. Shugart (2002, p. 345) has felicitously pointed out that ' $[\mathrm{t}]$ he possibility that the issues are more a lack of passion for learning, though, raises much more profound challenges for a learning-centered college'.

\section{Love and learning}

Love means deep caring for others, and it makes life worth living; in other words, love is an emotion of strong affection and personal attachment. Furthermore, love can be seen as a virtue or strength representing human kindness, compassion, and affection (e.g., Seligman et al., 2005). Love has many definitions and many faces as well: in addition to romantic love (Beck-Gernsheim \& Beck, 1995; Fenchel, 2005; Hatfield, 1988; Hegi \& Bergner, 2010; Määttä, 2005, 2006; Person, 2007; Sternberg, 1998), there are friendship (Alberoni, 1987; Blieszner \& Adams, 1992; Fehr, 1996; Hartup, 1995; Miller \& Perlman, 2009), love for fellow humans (Eriksson, 1989; Janako, 1993; Paldanius, 2002), parental love, love of one's country (Määttä, 2007), and pedagogical love (Haavio, 1954; Skinnari, 2004).

What about love for learning? Is it 'love', and how could it be defined? Because we have emphasized the demanding nature of studies, would it be reasonable to contemplate for a moment the idea of love for learning: what kinds of elements it could consist of and what the connection with success could be? Positive emotions support problem-solving skills and the ability to act in an innovative way and thus human well-being. The importance and potential of this may seem surprising because the feelings of happiness are so simple and common in nature (Isen, 2006).

Salmela (2016) studied Finnish high-achieving students' strengths and found out that love for learning along with curiosity and appreciation of versatile excellence formed the dimension of the thirst of knowledge and passion for learning in these top students (see also Salmela \& Uusiautti, 2015). It was noted that their quality of motivation in studies contributed to their individual performance 
and success as well as subjective well-being (Salmela \& Uusiautti, 2015; cf. also Deci \& Ryan, 2008). Furthermore, these students showed interest in, excitement of, and enjoyment from accomplishing a variety of learning tasks. Interestingly, love for learning in these top students was also connected with flow state, which shows that their intrinsic motivation made learning meaningful and worthwhile (see also Seligman, Ernst, Gillham, Reivich, \& Linkins, 2009).

\section{Also about satisfaction and well-being}

Love can be seen as a particular strength of character that is robustly associated with satisfaction in various organizations, including universities (Peterson \& Park, 2006). Happiness and satisfaction must be understood as the outcome of an interaction process between individual characteristics and aspirations on the one side and social relations and macro-social structures on the other side (Haller \& Hadler, 2006). Happy people perform better than those who report low wellbeing. Kaye (2010) points out that happiness can be directly translated into engagement, productivity, and satisfaction. Likewise, according to Lyubomirsky, King, and Diener (2005), positive affect is associated with multiple positive outcomes. Kinjerski and Skrypnek (2006) have listed factors that are associated with individuals' experiences of spirit at work. We have listed and translated some of these factors to describe the university context especially from the perspective of love for learning:

1) teachers, lecturers, and professors who inspire students through their example;

2) positive university culture, including a positive physical space for employees and students to work in;

3) positive connections among all members and a sense of community in the university;

4) opportunities for members to pursue professional and personal growth and to fulfill their own personal mission; and

5) appreciation and regard for the members of the university community.

Kinjerski's and Skrypnek's description is interesting because it presents only one reference on physical conditions (the positive physical space), but the others refer to inspiration, mission and purpose, good intention, and connections (including appreciation). All these elements strengthen the positive feeling toward studies.

It has been suggested that education should include training that increases positive emotion through training and activities on savoring and mindfulness, gratitude, optimism, and resilience, such as stress reductions skills training, lifeplanning and goal-setting skills training, and problem-solving skills training as well as training aiming at identifying students' signature strengths and having them use these strengths in their daily lives (Maddux, 2002).

Enhancing love for learning and improving proficiency can provide students with the feeling of mastery and self-development. This kind of a so-called perfect 


\section{The importance and essence of study success}

storm can lead to a much deeper and more personal engagement (see e.g., Flint, Kurumada, Fisher, \& Zisook, 2011). However, the predictive strength of affective reactions depends on social-contextual factors, such as the nature of the interpersonal relationship (e.g., cooperative or competitive), prevailing (cultural) norms (e.g., 'display rules'), and the way the emotions are expressed (Fischer \& van Kleef, 2010).

\section{Love and success}

It is worth remembering that university administration and personnel are the ones who initially develop a university culture that demonstrates concern for individual needs (Fairholm \& Fairholm, 2000) but consider and support students' personal life as well (Ransford, Crouter, \& McHale, 2008) and consider students as valuable customers (Määttä, 2015; Shugart, 2002). Yet the university where employees and students are happy should also make a profit in an economic sense. However, these two factors do not exclude each other. Happy employees exhibit higher levels of job-related performance behaviors than do unhappy employees (Wright, 2004) - and happy students love their studies and learning and perform efficiently. To illustrate the connection with this kind of success and love for learning, some of the latest studies have shown that a learning orientation in students is connected with productivity and a likelihood of better success in future careers as well (Hazari, Potvin, Tai, \& Almarode, 2010). Love for learning, when understood widely, provides one way of approaching success. It also highlights that academic excellence is not just about good grades but is comprehensively tied with human excellence, referring to positive features, such as commitment, integrity, openness, and self-development, and to positive social relationships (see Lumsden, 1999).

Therefore, love for learning is not just something that an individual student can experience but what she or he can spread in the university community and what can be enhanced through the university education as well. Hendrick (2015, p. 334) has stated that 'the capacity for love is a central component of all human societies'. Caldwell and Dixon (2010) have defined love, forgiveness, and trust as organizational constructs that are freedom producing and enhance efficacy. If a learner-type person who has a great desire to learn and who wants to improve continuously is combined with a hint of positivity (as presented by Clifton in Lopez et al., 2015), we will have student who loves learning and gets others excited about it, too!

\subsection{Study success as a process and outcome}

Studying is students' work, they say. How to be satisfied with or even successful in this kind of work is the main question of this final chapter of the book. Our purpose is to discuss how successful study progress and satisfaction with studies may be compared with the phenomenon of success and whether similar features of success determine the phenomenon in various areas of life. 
The rapidly changing modern society necessitates that new ways of securing students' satisfaction with their studies have to be discovered (Välijärvi et al., 2007). This is important if we want to prepare them to cope with the whirlpool of modern work (Bailey, 2014; Cascio, 2013), too, and to succeed in their future careers (Uusiautti \& Määttä, 2015b). New studies, such as the one conducted by Mari Salmela about Finnish straight-A graduates (Salmela, 2016), point out that traditional education usually emphasizes strengths related to critical thinking, pursuit of excellence, diligence, and high academic achievements, but it seems that other kinds of strengths might be more wanted in the world of work students enter after studies (Peterson, Stephens, Park, Lee, \& Seligman, 2013).

However, studying is also a long-term process. This means that success does not necessarily mean just the straight As at the end, but it is also reasonable to pay attention to all that happens before achieving the successful measurable study goals. Many studies have focused on describing teaching arrangements that enhance smooth study processes in higher education (Biggs, 2001; Määttä \& Uusiautti, 2012; Määttä, Uusiautti, \& Määttä, 2016; Samarawickrema \& Stacey, 2007).

Often, study satisfaction refers to elements that increase students' contentment with their study progress and smoothness of their study paths. They usually cover features of functional study environment (e.g., library services, information and communication technology support, classrooms), professional teaching personnel, and quality study structures (e.g., well-designed curricula, grading and evaluation systems) (Garrison \& Kanuka, 2004; Lenning \& Ebbers, 1999; Salmela et al., 2015). Students' satisfaction with their studies is boosted if they can plan studies autonomously and have abundant options of how, what, and when to study (Lizzio, Wilson, \& Simons, 2002). Actually, these features represent merely the study environment and conditions, which are important but just one dimension of an actual successful study process (Määttä et al., 2016).

Here, our purpose is to compare study success with the theory of success at work (Uusiautti, 2015b, 2016b). Success as a concept ignites some contradictory feelings: on the one hand, it is something desirable and worth pursuing, and on the other hand, it has negative connotations related to power, opportunism, and cold-heartedness. Our perspective is positive. According to it, success can consist of expertise, competence, and successes that come from intrinsic motivation and interest in one's doing; thus, success can be seen as a positive inner feeling of oneself (Uusiautti, 2008, 2015a; Uusiautti \& Määttä, 2015a). This positive state is multidimensional. When someone becomes riveted and senses the greatest self-fulfillment, he or she can achieve the state of flow (Csikszentmihalyi, 2008) and engagement and joy (Hakanen, Perhoniemi, \&Toppinen-Tanner, 2008; Mesurado, Richaud, \& Mateo, 2015; Stairs \& Galpin, 2013). Actually, freedom to choose - in other words, autonomy - enhances the capability to act, which can create the flow state so that accomplishing becomes possible, which again contributes to the sense of meaning in doing. This can be called 'the positive circle of intrinsic motivation' (Järvilehto, 2013; Martela \& Jarenko, 2014; Määttä, 2015), which can raise the student's motivation from 


\section{The importance and essence of study success}

disinterest and so-called shortcut-seeking behavior toward achievement motivation and genuine interest in learning and gaining profound knowledge in the field (Männikkö \& Pohjatalo, 2015; Määttä, 2015; Salmela \& Uusiautti, 2015 ).

The way we have outlined the phenomenon of success from a person's personal perspective can also be connected to other concepts that are closely related to positive manifestation of human development and agency (Brown Kirschman, Johnson, Bender, \& Roberts, 2009; Magnusson \& Mahoney, 2003; Maddux, 2002; Uusiautti \& Määttä, 2015b). One of them is the concept of positive psychological capital (Youssef \& Luthans, 2013) that is gained during studies, which can support succeeding when entering the world of work as well (Uusiautti \& Määttä, 2013). This 'PsyCap' consists of efficacy, hope, optimism, and resiliency and is used for explaining positive organizational behavior and development. As such, it still does not refer to success, but it complements our understanding about the positive phenomenon of success.

According to our previous studies (Uusiautti \& Määttä, 2015b; Uusiautti, 2016a), success at work appeared as a complex network of high performance, intrinsic motivation, drive and engagement, and development and competence. These factors are interesting from the viewpoint of success in studies as well. In sum, the positive experience of work is one of the most essential dimensions of success (Liden, Wayne, \& Sparrowe, 2000). However, when analyzing the phenomenon of success not just as an individual person's actions and characteristics, it becomes evident how the outer conditions and interpersonal relationships influence the process of success, too (Uusiautti, 2015a, 2015b, 2015c, 2016a). All these are interconnected - conditions, social relationships, and personal factors. The conclusion us that when the process is good, positive action and phenomena occur, too, leading to success as (measurable) outcomes. Would it be possible to analyze study success similarly?

In Figure 4.1, we have illustrated how study success can be viewed not only as good grades and graduations but also as fluent and pleasant study processes in which well-being and positivity exist and prevail.

On the one hand, students referred to flexible teaching arrangements and welldesigned courses and positive, encouraging interaction between the teaching personnel and peer students. They also appreciated prompt guidance practices and the sense of being appreciated. These items are represented in Figure 4.1 as social relationships at the university. Peer relationships, friendships, and pleasant encounters with teachers and professors (Bowman \& Akcaoglu, 2014; Määttä, 2015; Symonds, 2014) are important factors for success, especially when talking about study success as a process.

The students also mentioned variety of study methods (e.g., online lectures and exams) and other outer factors. Although they were not considered the main success factors, they have a crucial role in the successful study process as well. In all, functional study environment lays the basic foundation of success, which we also noticed in Chapter 4.2. 


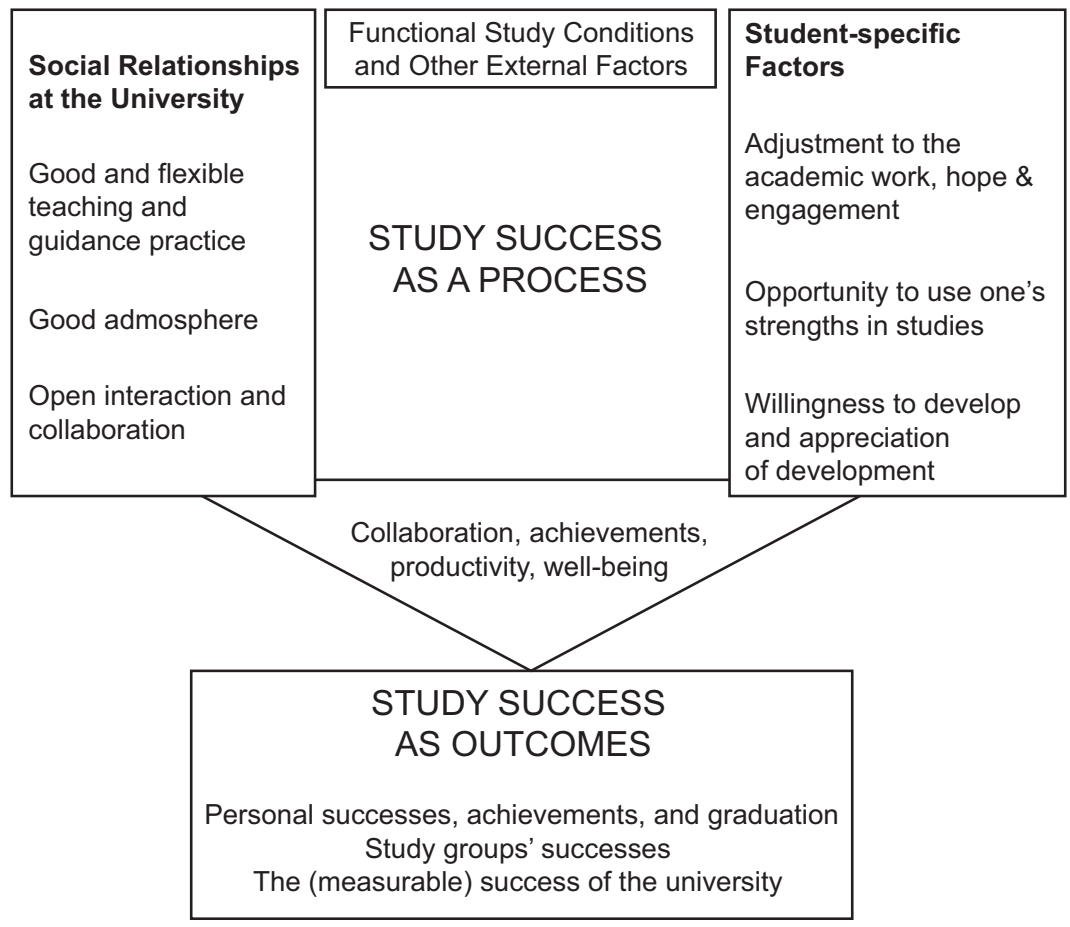

Figure 4.1 Study success as a process and outcomes (retelling Uusiautti, 2015b, p. 133)

In the right-hand-side of Figure 4.1, we have placed items that describe the students' own role in the successful study process. As the students' descriptions showed, they found situations in which they could recognize their development, find and use their strengths, and succeed well the most rewarding and the most important for their success. To a great extent, it is a matter of attitude they take in studies: whether they can cope with the new, changing study environment; new expectations and obligations; and self-directed, free academic study schedules. If they are able to adjust to these conditions in an open-minded and noble manner, their engagement to studies is likely to be high (Williams, Childers, \& Kemp, 2013). A positive attitude also shows hope - and that is needed during demanding university studies that will include hardships and tricky situations as well, as noted in Chapter 4.1. Studying is not sunshine every day but is also hard work. However, study work is easier if the students has the opportunity use her or his strengths in studies (Salmela \& Uusiautti, 2015). In this research, the students described how they had gained the sense of being in the right place, studying the right field. In these cases, we may interpret that they have found the field that suits their strengths the best. This can lead to not only maximal performance 
(Mitchell, 1997; see also Howell, 2009) but also to the greatest self-fulfillment and well-being in life (Ouweneel, Le Blanc, \& Schaufeli, 2011).

Finally, success includes the element of development. Some students in the data pointed out how they perceived their development as a part of their study success. When development becomes the goal, students show profound intrinsic motivation to become experts in their field; this feature also described Finnish top workers extremely well (see Uusiautti \& Määttä, 2015b). Likewise, Vansteenkiste et al. (2006) argue that intrinsic goal framing related to intrinsic motivation 'produces deeper engagement in learning activities, better conceptual learning, and higher persistence at learning activities' (p. 19).

The aforementioned factors summarized the study success as a process. However, when it comes to success, the element of achievements, including measurable ones, have a distinct role. Study success as outcomes refers to smooth study progress, high grades in courses, and timely graduation. These are the goals at which the majority of students aim. And actually, achieving as such has been regarded as one of the five important elements of well-being in human beings (Seligman, 2011; Uusiautti, Määttä, \& Leskisenoja, 2016). At the same time, study success as outcomes can manifest itself as the study group's productive work and fruitful collaboration. From the university's point of view, study success as outcomes is seen as efficient teaching; a high number of study points performed each semester; and, eventually, fast-graduating students. The latter is plainly one of the most important measurable goals of universities (Bunce, Baird, \& Jones, 2016).

Figure 4.1 illustrates how the positive process goes hand in hand with favorable outcomes. True study success is about both of them: well-being in students, teaching personnel, and the academic community tells about the success of study processes (Uusiautti \& Määttä, 2016). This kind of 'happiness advantage' (Achor, 2010) has been proven to lead to better productivity, efficiency, and results (Bunce et al., 2016).

Students should be equipped with understanding of their own capability to reach new goals and address various challenges and opportunities (Proctor, Maltby, \& Linley, 2011). Study success therefore means self-reflection as well - in other words, familiarization with one's abilities, strengths, and weaknesses (Linley et al., 2010) and using them actively and daring to lead life in their direction (Seligman, 2011).

However, to better meet the demands of modern life, education should support strengths that improve well-being, satisfaction, and positive behaviors and citizenship (see also Salmela \& Uusiautti, 2015) - in other words, learning how to be well and succeed in life.

Such strengths are, for example, gratitude, thoughtfulness, compassion, and teamwork (Park \& Peterson, 2009; Popov, 1997). There is an increasing understanding that these kinds of strengths contribute to social relationships and to the sense of meaning and well-being (Park \& Peterson, 2009) and are increasingly needed and appreciated in today's world of work, too. This is how study success at its best may contribute to these students' future as workers. 
Therefore, an interesting question that follows is can success in studies lead to success at work? When considering positive development from the point of view of success in studies, it becomes crucial to recognize factors that enhance success in a way that boosts positive self-image, awareness of one's strengths, and an optimistic attitude (Beard, Humberstone, \& Clayton, 2014; Rowe, Fitness, \& Wood, 2015). Experiences and events taking place in childhood, adolescence, and early adulthood can be crucial, or at least, direct and maintain people in a right direction in adulthood and later life (Gottfried, Fleming, \& Gottfried, 2001; Magnusson \& Mahoney, 2003). However, positive development is a holistic process of an individual person in which the cultural, physical, and historical context also matters. The main point is how well people can seize the opportunities or cope with the challenges their context provides. Therefore, the findings can be compared with several earlier studies on the importance of positive feedback, constructive evaluation, and good relationships at the university. At their best, they improve students' initiation and activity in their studies as well as their ability to detect their core strengths and evaluate their own learning and study skills (Boud \& Molloy, 2013; Carless, Salter, Yang, \& Lam, 2011).

Students not only appreciate but actually need endless feedback (West \& Turner, 2016) to develop as students, learners, and members of an academic community (Winstone, Nash, Rowntree, \& Parker, 2016). In addition to the support of the university community as a whole, all this is greatly based on positive attitudes towards studies and tasks, study community, and peers. Adopting a positive and optimistic attitude increases resilience during demanding university studies. The successes in studies that follow are likely to support the positive attitude and create a sense of self-efficacy that is not easily shaken by possible adversities (Maddux, 2002). It also exemplifies the positive psychological capital of knowing 'who I am' (Luthans, Luthans, \& Luthans, 2004). Success in studies, when understood from the perspective represented in this book, may at least enhance or improve students' chances of finding success in studies, too, because they possess the invaluable knowledge of themselves as learners and workers and have gained the inner zeal to develop as experts in their chosen fields that they are now studying and in which they will be working in the future.

When a human being is able to get the most of his or her resources, he or she is likely to get positive feedback and recognition from others, succeed, and have an increase in his or her self-appreciation. This kind of positive cycle lays the foundation to healthy development because it represents the true opportunity of self-fulfillment and boosts top performance. At its best, education offers a positive environment that enhances the development of children's strengths that are important to survival in the modern world: self-confidence and self-esteem, balanced emotional life, judgment and responsibility, the ability to control one's own behavior and make healthy choices, and empathy, as well as the ability to respect and appreciate other people represent such features (see Määttä, 2007). Although childhood is the optimal time to promote the recognition of children's strengths and building on those strengths (Brown Kirschman et al., 2009), this can and should be continued during high school and university studies and later in life as well (Seligman, 2011). 
Seligman (2011) has surfaced that pupils' flourishing 'will be aided by positive education, in which teachers embed the principles of well-being into what they teach, and the depression and anxiety of their students drop and their students' happiness rises' (p. 240). We also consider that by having the emphasis on the positive, by focusing on maintaining and nurturing pupils' resources, and through these actions pursuing to top performance, the competition- and efficiency-oriented world would become much healthier because the expectations could be met with positive strategies (Diener, Lucas, \& Napa Scollon, 2006; Locke, 2002). It is all about a good balance between positive and negative effects as Myers and Diener (1995) suggest. If university studies provide students with positive experiences about learning and themselves as students and learners to the extent that the positive state is dominant, students are more likely to feel satisfied with their studies and presumably life in general. Although negative affects - caused by adversities, failures, conflicts with peers, or just boring study tasks - occur in everyone's lives, it is important to have a positive basis with which to face the negative sides of studies. This keeps up emotional well-being (see also Keyes \& Annas, 2009).

New suggestions for the development of university teaching and university culture, too, have been created and are under development constantly, and they aim at providing meaningful studies for a variety of students (Anderson et al., 2011; Austin, 2002; Lumpkin, 2014; Hoessler, Godden, \& Hoessler, 2015; Romsdahl \& Hill, 2012; Uusiautti \& Määttä, 2013). Actually, the diversity of students is perceived as a richness in the current debates (Griffin, Muniz, \& Smith, 2016). The conclusion is that caring practices in universities provide positive experiences, initial excitement, and the enjoyment that is called flow, leading to top performance at its best.

Our fast-changing society requires a new kind of professionalism of teachers and professors that answers this expectation (Seidl \& Friend, 2002; von Wright, 2009). These kinds of educators try to find the road to better learning, development, performance, contentment, higher motivation, and the sense of self-efficacy in students. However, it is necessary to also understand that neither students' nor teachers' coping and motivation are automatic: the demands of studies and all expectations for performance have to be prioritized. Whereas students need the skills to recognize their own strengths and set limits to their study pace and achievements and maintain the balance between various areas of life, teachers in universities must filter the pressures they are given by the university, students, other teacher and researcher colleagues, and themselves (Määttä, 2015; see also Onnismaa, 2010). And yet, no one is perfect. Määttä $(2015$, p. 127) reminds that 'good teachers do not have to be perfect; no more than they selves can expect that students were or they should become perfect'. Everyone has to take care of their own well-being so that they are able to maintain motivation and activity in their studies or work at the university. In this book, we have had a glance at study success both from the students' perspective and from the teachers', professors', and other personnel's perspectives, too. As much as study success can be seen as 
a communal process, it always involves the student as a person, whose resources determine the fluency of his or her study path.

But what is the most important thing in university studies and study success from students' viewpoint, then? Without students' own activity and commitment, students' studies are not likely to proceed and become completed. Without their own effort and concentration, students' study points will not accumulate. In Duckworth's (2016) well-reasoned opinion, skills combined with effort result to achievement. So, students' own action, their inner motivation, and persistence to do well - and develop - are important. Feedback and counseling by teachers are certainly not the only success factors, but students' own willingness to learn from their experiences and self-reflect are equally crucial. Indeed, Winstone et al. (2016) point out that many students actually perceive feedback from teachers merely as luxury than necessity for their studies. However, a university that fosters students' development as academic learners and pays attention to students' needs; shows interest in learning from their experiences; and, first and foremost, shows willingness to improve teaching practices according to students' suggestions and feedback may be regarded as luxurious study places. Maybe universities should start competing which one of them provides this kind of luxury the most. The final argument is therefore that there cannot be true success in studies without a smooth, caring study process in which well-being is appreciated as much as the numeric goals of the students; teachers; and, in the end, the university as well.

\section{References}

Achor, S. (2010). The happiness advantage: The seven principles of positive psychology that fuel successes and performance at work. New York, NY: Crown Business.

Alberoni, F (1987). Falling in love. New York, NY: Random House Inc.

Anderson, W. A., Banerjee, U., Drennan, C. L., Elgin, S. C. R., Epstein, I. R., Handelsman, J., \& Strobel, S. A. (2011). Science education: Changing the culture of science education at research universities. Science, 331(6014), 152-153. doi:10.1126/science.1198280

Austin, A. E. (2002). Preparing the next generation of faculty: Graduate school as socialization to the academic career. The Journal of Higher Education, 73(1), 94-122. doi:10.1353/jhe.2002.0001

Bailey, T. (2014). Changes in the nature of work: Implications and skills for assessment. In H. F. O’Neill Jr. (Ed.), Workforce readiness: Competencies and assessment (pp. 27-46). New York, NY: Psychology Press.

Baltes, P. B., \& Freund, A. M. (2006). Ihmisen vahvuudet ja viisaus [The human strengths and wisdom]. In L. G. Aspinwall \& U. M. Staudinger (Eds.), Ibmisen vahvuuksien psykologia [A psychology of human strengths] (pp. 34-46). Helsinki: Edita.

Beard, C., Humberstone, B., \& Clayton, B. (2014). Positive emotions: Passionate scholarship and student transformation. Teaching in Higher Education, 19(6), 630643. doi:10.1080/13562517.2014.901950

Beck-Gernsheim, E., \& Beck, U. (1995). The normal chaos of love. Cambridge: Polity Press. 
Biggs, J. (2001). The reflective institution: Assuring and enhancing the quality of teaching and learning. Higher Education, 41(3), 221-238. doi:10.1023/A:1004181 331049

Blieszner, R., \& Adams, R. (1992). Adult relationships. London: Sage.

Boud, D., \& Molloy, E. (2013). Rethinking models of feedback for learning: The challenge of design. Assessment \& Evaluation in Higher Education, 38(6), 698712. doi:10.1080/02602938.2012.691462

Bowman, N. D., \& Akcaoglu, M. (2014). 'I see smart people!': Using Facebook to supplement cognitive and affective learning in the university mass lecture. The Internet and Higher Education, 23, 1-8.

Brickman, P., Coates, D., \& Janoff-Bulman, R. (1978). Lottery winners and accident victims: Is happiness relative? Journal of Personality \& Social Psychology, 36(8), 917-927. doi:10.1037/0022-3514.36.8.917

Brown Kirschman, K. J., Johnson, R. J., Bender, J. A., \& Roberts, M. C. (2009). Positive psychology for children and adolescents: Development, prevention, and promotion. In S. J. Lopez \& C. R. Snyder (Eds.), Oxford handbook of positive psychology (pp. 133-148). Oxford: Oxford University Press.

Bunce, L., Baird, A., \& Jones, S. E. (2016). The student-as-consumer approach in higher education and its effects on academic performance. Studies in Higher Education [Online]. doi:10.1080/03075079.2015.1127908

Caldwell, C., \& Dixon, R. D. (2010). Love, forgiveness, and trust: Critical values of the modern leader. Journal of Business Ethics, 93(1), 91-101. doi:10.1007/ s10551-009-0184-Z

Carless, D., Salter, D., Yang, M., \& Lam, J. (2011). Developing sustainable feedback practices. Studies in Higher Education, 36(4), 395-407. doi:10.1080/03075071003642449

Carver, C. S., \& Scheier, M. F. (2002). Optimism. In C. R. Snyder \& S. J. Lopez (Eds.), Handbook of positive psychology (pp. 231-243). Oxford: Oxford University Press.

Carver, C. S., \& Scheier, M. F. (2005). Engagement, disengagement, coping, and catastrophe. In A. J. Elliot \& C. S. Dweck (Eds.), Handbook of competence and motivation (pp. 527-547). New York and London: The Guilford Press.

Cascio, W. F. (2013). The changing world of work. In P. A. Linley, S. Harrington, \& N. Garcea (Eds.), The Oxford handbook of positive psychology and work (pp. 13-24). Oxford: Oxford University Press.

Covey, S. R. (2006). Tie menestykseen: 7 toimintatapaa henkilökobtaiseen kasvuun ja muntokseen [Road to success: 7 methods of personal growth and change] (5th ed.). Jyväskylä: Gummerus.

Csikszentmihalyi, M. (2008). Finding flow: The psychology of engagement with everyday life. New York, NY: Basic Books.

Deci, E. L., \& Ryan, R. M. (2008). Facilitating optimal motivation and psychological well-being across life's domains. Canadian Psychology, 49(1), 14-23. doi:10.1037/0708-5591.49.1.14

Diener, E., Lucas, R. E., \& Napa Scollon, C. (2006). Beyond the hedonic treadmill. Revising the adaptation theory of well-being. American Psychologist, 61(4), 305-314. doi:10.1037/0003-066X.61.4.305

Duckworth, A. (2016). GRIT: The power of passion and perseverance. New York, NY: Scribner.

Eriksson, K. (1989). Caritas-idea [The idea of Caritas]. Hämeenlinna: Karisto. 
Fairholm, M. R., \& Fairholm, G. (2000). Leadership amid the constraints of trust. Leadership \& Organization Development Journal, 21(1/2), 102-109.

Fehr, B. (1996). Friendship processes. London: Sage.

Fenchel, G. H. (2005). What is love? Issues in Psychoanalytic Psychology, 27(1), 49-67.

Fischer, A. H., \& van Kleef, G. A. (2010). Where have all the people gone? A plea for including social interaction in emotion research. Emotion Review, 2(3), 208-211. doi:10.1177/1754073910361980

Flint, A. S., Kurumada, K. S., Fisher, T., \& Zisook, K. (2011). Creating the perfect storm in professional development: The experiences of two American teachers and a university research team. Professional Development in Education, 37(1), 95-109

Freund, A. M., \& Baltes, P. B. (1998). Selection, optimization, and compensation as strategies of life management: Correlations with subjective indicators of successful aging. Psychology and Aging, 13(4), 531-543. doi:10.1037/0882-7974.13.4.531

Garrison, D. R., \& Kanuka, H. (2004). Blended learning: Uncovering its transformative potential in higher education. Internet and Higher Education, 7(2), 95-105. doi:10.1016/j.iheduc.2004.02.001

Gillham, J., \& Reivich, K. (2004). Cultivating optimism in childhood and adolescence. The ANNALS of the American Academy of Political and Social Science, 591, 146-163. doi:10.1177/0002716203260095

Gottfried, A. E., Fleming, J. S., \& Gottfried, A. W. (2001). Continuity of academic intrinsic motivation from childhood through late adolescence: A longitudinal study. Journal of Educational Psychology, 93(1), 3-13. doi:10.1037/0022-0663.93.1.3

Griffin, K. A., Muniz, M., \& Smith, E. J. (2016). Graduate diversity officers and efforts to retain students of color. Journal of Student Affairs Research and Practice, 53(1), 26-38. doi:10.1080/19496591.2016.1083437

Haavio, M. (1954). Opettajapersoonallisuus [Teacher personality]. Jyväskylä: Gummerus.

Hakanen, J., Perhoniemi, R., \& Toppinen-Tanner, S. (2008). Positive gain spirals at work: From job resources to work engagement, personal initiative and workunit innovativeness. Journal of Vocational Behavior, 73, 78-91. doi:10.1016/j. jvb.2008.01.003

Haller, M., \& Hadler, M. (2006). How social relations and structures can produce happiness and Organizational Behavior and Human Performance, 16, 250-279.

Hartup, W. (1995). The three faces of friendship. Journal of Social and Personal Relationships, 12(4), 569-574.

Hatfield, E. (1988). Passionate and companionate love. In R. Sternberg \& M. Barnes (Eds.), The psychology of love (pp. 191-217). New Haven, CT: Yale University Press.

Hazari, Z., Potvin, G., Tai, R. H., \& Almarode, J. (2010). For the love of learning science: Connecting learning orientation and career productivity in physics and chemistry. Physical Review Special Topics - Physics Education Research, 6(1), 010107-1-9. doi:10.1103/PhysRevSTPER.6.010107

Hegi, L. E., \& Bergner, R. M. (2010). What is love? An empirically-based essentialist account. Journal of Social and Personal Relationships, 27(5), 620-636.

Hendrick, S. (2015). Love. In S. J. Lopez, J. Teramoto Pedrotti, \& C. R. Snyder (Eds.), Positive psychology: The scientific and practical explorations of human strengths (pp. 334-337). Thousand Oaks, CA: Sage.

Hoessler, C., Godden, L., \& Hoessler, B. (2015). Widening our evaluative lenses of formal, facilitated, and spontaneous academic development. International Journal for Academic Development, 20(3), 224-237. doi:10.1080/1360144X.2015.1048515 


\section{The importance and essence of study success}

Howell, A. J. (2009). Flourishing: Achievement-related correlates of students' wellbeing. The Journal of Positive Psychology, 4(1), 1-13. doi:10.1080/17439760802 043459

Hyvärinen, S., \& Uusiautti, S. (2014). Safe and encouraging home providing the countdown to leadership? Finnish female leaders' childhood memories. Early Child Development and Care, 184(11), 1723-1740. doi:10.1080/03004430.2013.876626

Isen, A. M. (2006). Myönteinen tunne ihmisen vahvuuden lähteenä [Positive feeling as a source of human strength]. In L. G. Aspinwall \& U. M. Staudinger (Eds.), Ibmisen vahvuuksien psykologia [The psychology of human strengths] (pp. 186-201). Helsinki: Edita.

Janako, B. J. (1993). Caring is loving. Journal of Advanced Nursing, 18, 192-194.

Järvilehto, L. (2013). Upeaa työtä! [Great work!]. Helsinki: Tammi.

Karasek, R., \& Theorell, T. (1990). Healthy work: Stress, productivity, and reconstruction of working life. New York, NY: Basic Books.

Kaye, B. (2010). Career Development: It's now a business imperative. Leadership Excellence, 27(1), 1.

Keyes, C. L. M., \& Annas, J. (2009). Feeling good and functioning well: Distinctive concepts in ancient philosophy and contemporary science. Journal of Positive Psychology, 4(3), 197-201. doi:10.1080/17439760902844228

Kinjerski, V., \& Skrypnek, B. J. (2006). Creating organizational conditions that foster employee spirit at work. Leadership \& Organization Development Journal, 27(4), 280-295. doi:10.1108/01437730610666037

Latham, G. P., \& Pinder, C. C. (2005). Work motivation theory and research at the dawn of the twenty-first century. Annual Review of Psychology, 56, 485-516. doi:10.1146/annurev.psych.55.090902.142105

Lenning, O. T., \& Ebbers, L. H. (1999). The powerful potential of learning communities: Improving Education for the Future. ASHE-ERIC Higher Education Report, 26(6). Washington, DC: The George Washington University. Retrieved from http://files.eric.ed.gov/fulltext/ED428606.pdf

Liden, R. C., Wayne, S. J., \& Sparrowe, R. T. (2000). An examination of the mediating role of psychological empowerment on the relations between the job, interpersonal relationships, and work outcomes. Journal of Applied Psychology, 85(3), $407-416$.

Linley, A., Willars, J., \& Biswas-Diener, R. (2010). The strengths book: Be confident, be successful, and enjoy better relationships by realizing the best of you. Coventry: CAPP Press.

Lizzio, A., Wilson, K., \& Simons, R. (2002). University students' perceptions of the learning environment and academic outcomes: Implications for theory and practice. Studies in Higher Education, 27(1), 27-52. doi:10.1080/03075070120099359

Locke, E. A. (2002). Setting goals for life and happiness. In C. R. Snyder \& S. J. Lopez (Eds.), Handbook of positive psychology (pp. 299-312). Oxford: Oxford University Press.

Lopez, S. J., Teramoto Pedrotti, J., \& Snyder, C. R. (Eds.). (2015). Positive psychology: The scientific and practical explorations of human strengths. Los Angeles, CA: Sage.

Lumpkin, A. (2014). The role of organizational culture on and career stages of faculty. The Educational Forum, 78(2), 196-205. doi:10.1080/00131725.2013.878 420

Lumsden, L. (1999). Student motivation: Cultivating a love of learning. Eugene, OR: ERIC Clearing House on Educational Management. 
Luthans, F., Luthans, K. W., \& Luthans, B. C. (2004). Positive psychological capital: Beyond human and social capital. Business Horizons, 47(1), 45-50. doi:10.1016/j. bushor.2003.11.007

Lyubomirsky, S., King, L., \& Diener, E. (2005). The benefits of frequent positive affect: Does happiness lead to success? Psychological Bulletin, 131(6), 803-855. doi:10.1037/0033-2909.131.6.803

Määttä, K. (2005). Kestävä parisubde [Long-lasting intimate relationship]. Juva, Finland: WSOY.

Määttä, K. (2006). Rakastumisen lumous [The fascination of falling in love]. Juva, Finland: WSOY.

Määttä, K. (2015). Mistä pubutaan kun puhutaan opettamisesta Lapin yliopistossa? Kabviokeskustelun virtaa [What do we talk about when we talk about teaching at the University of Lapland? Flow of cafeteria discussion]. Rovaniemi: University of Lapland.

Määttä, K. (Ed.). (2007). Helposti särkyvää -nuoren kasvun turvaaminen [Fragile securing youngsters' growth]. Helsinki: Kirjapaja

Määttä, K., \& Uusiautti, S. (2012). How to enhance the smoothness of university students' study paths. International Journal of Research Studies in Education, 1(1), 47-60. doi:105861/ijrse.2012.vlil.16

Määttä, K., Uusiautti, S., \& Määttä, M. (2016). A story of an ideal study process. In S. Uusiautti \& K. Määttä (Eds.), The basics of caring research (pp. 91-102). Rotterdam: Sense Publishers.

Maddux, J. E. (2002). Self-efficacy: The power of believing you can. In C. R. Snyder \& S. J. Lopez (Eds.), Handbook of positive psychology (pp. 277-287). Oxford: Oxford University Press.

Magnusson, D., \& Mahoney, J. L. (2003). A holistic person approach for research on positive development. In L. G. Aspinwall \& U. M. Staudinger (Eds.), A psychology of human strengths (pp. 227-244). Washington, DC: APA.

Männikkö, L., \& Pohjatalo, A. (2015). Opiskelumotivaatio [Study motivation]. OK-opintokeskus. Retrieved from http://kouluttaja.ok-opintokeskus.fi/opiskelu motivaatio.

Martela, F., \& Jarenko, K. (2014). Sisäinen motivation: Tulevaisuuden työssä tuottavuns ja innostus kohtaavat [Intrinsic motivation: In the future work, productivity and enthusiasm encounter]. Helsinki: Lahden tutkimus- ja koulutuskeskus.

Maslach, C., \& Leiter, M. P. (1999). Burnout and engagement in the workplace: A contextual analysis. In T. C. Urdan (Ed.), The role of context: Advances in motivation and achievement Vol. 11 (pp. 275-302). Bingley: JAI Press.

Mesurado, B., Richaud, M. C., \& Mateo, N. J. (2015). Engagement, flow, self-efficacy, and eustress of university students: A cross-national comparison between the Philippines and Argentina. The Journal of Psychology, 150(3), 1-24. doi:10.1080/0 0223980.2015 .1024595

Miller, R., \& Perlman, D. (2009). Intimate relationships. Boston, MA: McGraw-Hill.

Mitchell, T. R. (1997). Matching motivational strategies with organizational contexts. Research in Organizational Behavior, 19, 57-149.

Myers, D. G., \& Diener, E. (1995). Who is happy? Psychological Science, 6(1), 10-19.

Oberle, E., Schonert-Reichl, K. A., Guhn, M., Zumbo, B. D., \& Hertzman, C. (2014). The role of supportive adults in promoting positive development in middle childhood: A population-based data. Canadian Journal of School Psychology, 29(4), 296-316. doi:10.1177/0829573514540116 


\section{The importance and essence of study success}

Onnismaa, J. (2010). Opettajien työhyvinvointi: Katsaus opettajien työhyvinvointitutkimuksiin 2004-2009 [Teachers' well-being at work: A review of teachers' wellbeing surveys in 2004-2009]. Helsinki: Finland's National Board of Education. Retrieved from www.oph.fi/download/124603_Opettajien_tyohyvinvointi.pdf

Ouweneel, E., Le Blanc, P. M., \& Schaufeli, W. B. (2011). Flourishing students: A longitudinal study on positive emotions, personal resources, and study engagement. The Journal of Positive Psychology, 6(2), 142-153. doi:10.1080/17439760. 2011.558847

Paldanius, A. (2002). Lähimmäisenrakkaus hoitotyön koulutuksessa [Caring in nursing education]. Acta Universitatis Lapponiensis No. 45. Rovaniemi, Finland: University of Lapland.

Park, N., \& Peterson, C. (2009). Strengths of character in schools. In R. Gilman, E. S. Huebner, \& M. J. Furlong (Eds.), Handbook of positive psychology in schools (pp. 65-76). New York, NY: Routledge.

Paulsson, K., Ivergård, T., \& Hunt, B. (2005). Learning at work: Competence development or competence-stress. Applied Ergonomics, 36(2), 135-144. doi:10.1016/j. apergo.2004.09.008

Person, E. S. (2007). Dreams of love and fateful encounters: The power of romantic passion. New York, NY: W.W. Norton \& Co.

Peterson, C. (2000). The future of optimism. American Psychologist, 55(1), 44-55. doi:10.1037/0003-066X.55.1.44

Peterson, C., \& Park, N. (2006). Character strengths in organizations. Journal of Organizational Behavior, 27(8), 1149-1154. doi:10.1002/job.398

Peterson, C., Seligman, M. E. P., \& Vaillant, G. E. (1988). Pessimistic explanatory style is a risk factor for physical illness: A thirty-five year longitudinal study. Journal of Personality and Social Psychology, 55(1), 23-27. doi:10.1037/0022-3514.55.1.23

Peterson, C., Stephens, J. P., Park, N., Lee, F., \& Seligman, M. E. P. (2013). Strengths of character and work. In P. A. Linley, S. Harrington, \& N. Garcea (Eds.), The Oxford handbook of positive psychology and work (pp. 221-234). Oxford: Oxford University Press.

Peterson, S. J., \& Luthans, F. (2003). The positive impact and development of hopeful leaders. Leadership er Organization Development Journal, 24(1), 26-31. doi:10.1108/01437730310457302

Popov, K. L. (1997). The family virtues guide: Simple ways to bring out the best in our children and ourselves. New York, NY: Penguin Group.

Proctor, C., Maltby, J., \& Linley, P. A. (2011). Strengths use as a predictor of wellbeing and health-related quality of life. Journal of Happiness Studies, 12(1), 153169. doi:10.1007/s10902-009-9181-2

Ransford, C. R., Crouter, A. C., \& McHaleb, S. M. (2008). Implications of work pressure and supervisor support for fathers', mothers' and adolescents' relationships and well-being in dualearner families. Community, Work \& Family, 11(1), 37-60. doi:10.1080/13668800701785312

Reivich, K., \& Gillham, J. (2003). Learned optimism: The measurement of explanatory style. In S. J. Lopez \& C. R. Snyder (Eds.), Positive psychological assessment: $A$ handbook of models and measures (pp. 57-74). Washington, DC: American Psychological Association.

Reivich, K., Gillham, J. E., Chaplin, T. M., \& Seligman, M. E. P. (2013). From helplessness to optimism: The role of resilience in treating and preventing depression in youth. In S. Goldstein \& R. B. Brooks (Eds.), Handbook of resilience in children (pp. 201-214). New York, NY: Springer. 
Romsdahl, R. J., \& Hill, M. J. (2012). Applying the learning community model to graduate education: Linking research and teaching between core courses. Teaching in Higher Education, 17(6), 722-734. doi:10.1080/13562517.2012.678325

Rowe, A. D., Fitness, J., \& Wood, L. N. (2015). University student and lecturer perceptions of positive emotions in learning. International Journal of Qualitative Studies in Education, 28(1), 1-20. doi:10.1080/09518398.2013.847506

Salmela, M. (2016). Tie ylioppilastutkinnon huippuarvosanoibin laudaturylioppilaiden kertomana [Paths to the highest scores in the Finnish Matriculation Examination as described by straight-a graduates]. PhD Diss., University of Lapland, Rovaniemi, Finland.

Salmela, M., \& Uusiautti, S. (2015). A positive psychological viewpoint for success at school - Ten characteristic strengths of the Finnish high-achieving students. High Ability Studies, 26(1), 117-137. doi:10.1080/13598139.2015.1019607

Salmela, M., Uusiautti, S., \& Määttä, K. (2015). Finnish high-achieving students' perceptions of the best practices in teaching. International Journal of Education, $7(2), 126-145$.

Samarawickrema, G., \& Stacey, E. (2007). Adopting web-based learning and teaching: A case study in higher education. Distance Education, 28(3), 313-333. doi:10.1080/01587910701611344

Schneider, S. L. (2001). In search of realistic optimism: Meaning, knowledge, and warm fuzziness. American Psychologist, 56(3), 250-263. doi:10.1037/0003-066X.56.3.250

Schunk, D. H., \& Pajares, F. (2005). Competence perceptions and academic functioning. In A. J. Elliot \& C. S. Dweck (Eds.), Handbook of competence and motivation (pp. 85-104). New York and London: The Guilford Press.

Seidl, B., \& Friend, G. (2002). Leaving authority at the door: Equal-status communitybased experiences and the preparation of teachers for diverse classrooms. Teaching and Teacher Education, 18(4), 421-433. doi:10.1016/S0742-051X(02)00007-0

Seligman, M. E. P. (2011). Flourish: A visionary new understanding of happiness and well-being. New York, NY: FreePress.

Seligman, M. E. P., Ernst, R. M., Gillham, J., Reivich, K., \& Linkins, M. (2009). Positive education: Positive psychology and classroom interventions. Oxford Review of Education, 35(3), 293-311. doi:10.1080/03054980902934563

Seligman, M. E. P., Steen, T. A., Park, N., \& Peterson, C. (2005). Positive psychology progress. Empirical validation of interventions. American Psychologist, 60(5), 410-421. doi:10.1037/0003-066X.60.5.410

Shepperd, J. A., Ouellette, J. A., \& Fernandez, J. K. (1996). Abandoning unrealistic optimism: Performance estimates and the temporal proximity of self-relevant feedback. Journal of Personality and Social Psychology, 70(4), 844-855. doi:10.1037/0022-3514.70.4.844

Shugart, S. C. (2002). Love of learning. Community College Journal of Research and Practice, 26(4), 345-348. doi:10.1080/106689202753546484

Skinnari, S. (2004). Pedagoginen rakkaus: Kasvattaja elämän tarkoituksen ja ihmisen arvoituksen äärellä [Pedagogical love: Educator by the meaning of life and riddle of human being]. Jyväskylä: PS-Kustannus.

Snyder, C. R. (2002). Hope theory: Rainbows in the mind. Psychological Inquiry: An International Journal for the Advancement of Psychological Theory, 13(4), 249-275. doi:10.1207/S15327965PLI1304_01

Snyder, R., Irving, L., \& Anderson, J. R. (1991). Hope and health: Measuring the will and the ways. In C. R. Snyder \& D. R. Forsyth (Eds.), Handbook of social and clinical psychology: The health perspective (pp. 285-305). Elmsford, NY: Pergamon. 
Stairs, M., \& Galpin, M. (2013). Positive engagement: From employee engagement to workplace happiness. In P. A. Linley, S. Harrington, \& N. Garcea (Eds.), The Oxford handbook of positive psychology and work (pp. 155-172). Oxford: Oxford University Press.

Sternberg. R. J. (1998). Love is a story: A new theory of relationships. Oxford: Oxford University Press.

Sweeny, K., Carroll, P. J., \& Shepperd, J. A. (2006). Is optimism always best? Future outlooks and preparedness. Current Directions in Psychological Science, 15(6), 302306. doi:10.1111/j.1467-8721.2006.00457.x

Symonds, M. R. (2014). Lecturing and other face-to-face teaching - too much or too little? An assessment based on student feedback and fail rates. Higher Education Research \& Development, 33(6), 1221-1231. doi:10.1080/07294360.2014. 911256

Uusiautti, S. (2008). 'Tänään teen elämäni parhaan työn'. Työmenestys Vuoden Työntekijöiden kertomana ['Today, I'll work better than ever'. Employees of the year describe their experiences of success at work]. PhD Diss., University of Lapland, Rovaniemi, Finland.

Uusiautti, S. (2013). On the positive connection between success and happiness. International Journal of Research Studies in Psychology, 3(1), 1-11. doi:10.5861/ ijrsp.2013.509

Uusiautti, S. (2015a). Success at work requires the ability to life-long learning. The 4th International Conference on Education, June 29-July 1, St. Petersburg, Russia.

Uusiautti, S. (2015b). Menestyvä ja hyvinvoiva yritys positiivisen psykologian valossa. Yritysjohdon ja työntekijöiden näkemyksiä menestyksestä [Successful and thriving enterprise in the light of positive psychology. Leaders' and employees' perceptions of success]. Helsinki: BoD.

Uusiautti, S. (2015c). Success at work requires successful leaders? The elements of successful leadership according to leaders and employees in a Finnish mid-size enterprise. International Journal of Research Studies in Psychology, 4(3), 49-65. doi:10.5861/ijrsp.2015.1164

Uusiautti, S. (2016a). Hope at work. In L. Bormans (Ed.), The world book of hope (pp. 222-225). Tielt: Lannoo.

Uusiautti, S. (2016b). Success at work requires hope and the ability to engage in an optimistic attitude. European Journal of Workplace Innovation, 2(2), 41-64.

Uusiautti, S., \& Määttä, K. (2013). Enhancing student' study success through caring leadership. European Scientific Journal, 2(2), 398-407.

Uusiautti, S., \& Määttä, K. (2015a). Positive psychological viewpoints to successful leadership. In A. M. Columbus (Ed.), Advances in psychology research Vol. 101 (pp. 93-104). New York, NY: Nova Science Publishers.

Uusiautti, S., \& Määttä, K. (2015b). The psychology of becoming a successful worker: Research on the changing nature of achievement at work. New York, NY: Routledge.

Uusiautti, S., \& Määttä, K. (2016). Caring research and its future challenges. In S. Uusiautti \& K. Määttä (Eds.), The basics of caring research (pp. 137-144). Rotterdam: Sense Publishers.

Uusiautti, S., Määttä, K., \& Leskisenoja, E. (2016). Why is success at work important? A case study in a midsized Finnish enterprise. Journal for International Business and Entrepreneurship Development, 9(3), 291-310. 
Välijärvi, J., Kupari, P., Linnakylä, P., Reinikainen, P., Sulkunen, S., Törnroos, J., \& Arffman, I. (2007). The Finnish success in PISA - And some reasons behind it 2. PISA 2003. Jyväskylä: Institute for Educational Research.

Vansteenkiste, M., Lens, W., \& Deci, E. L. (2006). Intrinsic versus extrinsic goal contents in self-determination theory: Another look at the quality of academic motivation. Educational Psychologist, 41(1), 19-31. doi:10.1207/s15326985ep4101_4

von Wright, M. (2009). The shunned essentials of pedagogy: Authority, love and mystery. Nordic Philosophy of Education Network NERA Annual Meeting, Trondheim, March 5-7. Retrieved from http://oru.diva-portal.org/smash/record. jsf?pid=diva2:212954

West, J., \& Turner, W. (2016). Enhancing the assessment experience: Improving student perceptions, engagement and understanding using online video feedback. Innovations in Education and Teaching International, 53(4), 400-410. doi:10.10 80/14703297.2014.1003954Williams, K. H., Childers, C., \& Kemp, E. (2013). Stimulating and enhancing student learning through positive emotions. Journal of Teaching in Travel o Tourism, 13(3), 209-227. doi:10.1080/15313220.2013.8 13320

Winstone, N. E., Nash, R. A., Rowntree, J., \& Parker, M. (2016, August 20). 'It'd be useful, but I wouldn't use it': Barriers to university students' feedback seeking and recipience. Assessment \& Evaluation in Higher Education [Online]. doi:10.1080/ 02602938.2015.1075956

Wright, T. A. (2004). The role of 'happiness' in organizational research: Past, present and future directions. In P. L. Perrewe \& D. C. Ganster (Eds.), Exploring interpersonal dynamics research in occupational stress and well-being Vol. 4 (pp. 221-264). Bingley: Emerald Insight.

Xanthopoulou, D., Bakker, A. B., Demerouti, E., \& Schaufeli, W. B. (2009). Reciprocal relationships between job resources, personal resources, and work engagement. Journal of Vocational Behavior, 74(3), 235-244. doi:10.1016/j.jub.2008.11.003

Youssef, C. M., \& Luthans, F. (2013). An integrated model of psychological capital in the workplace. In P. A. Linley, S. Harrington, \& N. Garcea (Eds.), The Oxford handbook of positive psychology and work (pp. 277-288). Oxford: Oxford University Press. 

Taylor \& Francis http://taylorandfrancis.com 


\section{Index}

Page numbers in italics indicate figures and tables.

absorption $42-3$

academic community: caring 8,71 ; and feedback 29; in ideal study process 20 , 96; and love 122; socialization in 79; and student success 19-20, 104, 126; and student support 97, 115, 127; and teachers $3,80,105,127$; and well-being 2

academic studies 22, 79; see also university education

achievement: elements of 126, 129; independent 79; and intrinsic motivation 26; paths to 47; personal 74 ; social support for 101 ; strengths for 123; and supervisors 38; and teachers 99, 103-4; and well-being $44,82,116,118$

Achor, Shawn 101, 117

Ackerman, P. L. 31

alienation 35

autonomy $28,34,100,123$

Baltes, P. B. 118

behavior: affective 84 ; control of 127 ; elements of 30; and expectation 117; and motivation $31,100,124$; positive 49, 126; and relationships 39; selfcentered 115; and social media 50; in work situations 101, 122

Berscheid, E. 39

Bloom's taxonomy 77

bonding $52-3$

Bouhnik, D. 87

Bourdieu, P. 50

Caldwell, C. 73,122

caring ethic 73

caring supervision $90-8$ caring teacherhood: and belief in work 100; and challenges 99-100; and commitment 104; and curriculum planning 76-7; and customerstudents 74-5; and flow 98-9; and motivation 100; nature of 73 ; and principles of education 75 ; and responsibility 104; and rewarding work 104; and student engagement 71 ; from a student perspective $74-5$; and student success $72-3,76,103-5$; and teaching methods $77-8$; and tutoring 78-9

Carroll, J. 50

Carroll, P. J. 119

Carver, C. S. 40,118

chatting 88

Cheung, R. K. H. 103

collaboration: enhancing 102-3; student 56-7; teacher 98-9, 101-2

collaborative learning 83

commitment 40, 91, 104

communality 54

community: in education 89,121 ; lack of 23; social 39; work 102; see also academic community

competence: defining 31 ; professional $100-1$; and success 115

constructive evaluation 29

courage 46

Covey, S. R. 118

Cruce, T. 71

Csikszentmihalyi, Mihaly 8, 42-3, 99

cultural capital 50

curriculum planning: and learning goals 75-7; and quality teaching 76-7; stages of 75 ; and study processes 21 customer-students $74-5$ 
Dabbagh, N. 55

Darling-Hammond, L. 103

data collection: and doctoral students 7-8; and master's students 8-9; methodology for 6-11; reliability of 7-9; and self-reflection 9

degree conferral 48

Diener, E. 121, 128

dissertation process: becoming hooked on 33-4; demands and expectations of 35-6; and flow 41-4; and meaningfulness $43-4$; phases of $32-8$; rewards of 38 ; support services for 38 ; as a top performance $29-32,38-41$, 43-4; and well-being 34

distance learning 87; see also online teaching

Dixon, R. D. 73, 122

doctoral students: change and strengthening of 37-8; dissertation process of 29-44; and feeling of alienation 35; and human relationships 39-40; and perception of time 43; and performance $30-1$, 39-40; positive emotions of 39 ; proactive attitude of 40 ; and selfdiscipline 40; and self-fulfillment 41; and sense of control 43; and social life 34-5; and supervisors 35-7, 44, 90-8; and support 38, 40; well-being of 34

doctoral thesis: demands and expectations for 35-6; impact of 29-37; phases of 32-8; requirements of 37 ; and social life $34-5$; standards for 29; supervision of $90-5$; as a top performance $30-1,38-41$

Duckworth, A. 129

economic capital 50

Ellison, N. B. 50

emotional intelligence 73

emotion-based attachments 72

engagement 119; see also student engagement

enthusiasm 46-7

exams 24-5

experiences of success see success experiences

Facebook 50

feedback: importance of 28, 127, 129; positive $20,28-9,41$; supervisor 37
Finland: degree conferral 48; free university education in $1,45,74$; school system in 1 ; teacher tutors in 79

flexibility $27-8$

flow: achievement of 99; and caring teacherhood 98-9; defining 41-2, 99; and the dissertation process 41-4; and love 99; and love of learning 121; and meaningfulness 44; and self-fulfillment 123

forgiveness 73

Freund, A. M. 118

functional guidance 79

garlands 48-9

Gillham, J. 117

goals: defining 31 ; meeting 118 ; and optimism 116-17

Goleman, Daniel 76, 99

group discussions 85,88

guidance: functional 79 ; lack of 23 ; quality 75

happiness $73,103,121-2$

happiness advantage 126

Hendrick, S. 122

hidden curriculum 76

high performance cycle 40

hope 117-20, 125

human relationships $38-40$

information sharing 53

interaction: in online teaching 86-9; student 51-2, 55-7, 80-1, 87, 90; student-teacher 81, 87-90; through social media $51-2,55$

internet communication 49-50

intrinsic motivation $20,26,100,103$, $116,121,123-4,126$

Jokinen, T. 79

Kanfer, R. 31

Karjalainen, A. 104

Kavanaugh, A. 50

Kaye, B. 121

Kearsly, Greg 89

Kezar, A. J. 56, 72

King, L. 121

Kinjerski, V. 121

Kinzie, J. L. 56, 72

Kitsantas, A. 55 
knowledge 93-4

Kuh, G. 74

Lähteenoja, S. 55, 81

Lampe, C. 50

Latham, G. P. 40

learning environments: factors for positive 72; online 83-90; personal 55 ; and social media $54-5$

learning goals $75-7$

lecturing 78

Lehtinen, E. 78

Leskisenoja, E. 57

literacies 55

Locke, E. A. 40, 118

loneliness 23

Lopez, S. J. 100

love: defining 120; in education

$71-3$; as a flow experience 99 ; as an organizational construct 73 ; as a strength of character 121 ; and success 122

love of learning 120-2

Luthans, F. 117

Lynch, K. 31

Lyubomirsky, S. 121

Määttä, K. 128

Maddux, J. E. 119

Marcus, T. 87

marketing and communication 53

Mason, R. 55

master's garland 49

maximal performance 31

meaningfulness 43-4, 56, 116

mentoring 29, 55-6

Mitchell, T. R. 31

motivation $20,30-1,56,100,115$, $123-4,126$

Myers, D. G. 128

Nummenmaa, A. R. 79

online peer support $49,52-3$

online teaching: benefits of 83 ;

disadvantages of 83 ; group discussions

in 85,88 ; ideal 89 ; interaction in

86-90; positive factors of $83-6$; student experiences of $83-7$; teacher attitude in 89; technical problems with 86

online tutoring 79

open atmosphere 25-6 optimism 116-19

organizational constructs 73

overeducation 29

overlapping courses 24

Paltridge, Brian 95

Pascarella, E. T. 71

patience 46

peer evaluations 5

peer relationships 56-7

peer support groups $49,52-3$

performance: concept of $30-1$; doctoral thesis as 30-1, 38-9; elements of 30 ; individual-specific requirements for 39-40; maximal 31; motivational base of 30 ; and self-efficacy 31 ; typical 31

PERMA theory 48

personal learning environments $\mathbf{5 5}$

Peterson, C. 117

Pietarinen, J. 40

positive affect 121-2

positive atmosphere 101-2

positive attitudes 125

positive emotions 39

positive feedback 20, 28-9, 41, 127

positive learning environments 72

positive organizations 103

positive psychological capital 124

positive strategies $115,118,128$

positive thinking 56

practicums 27

principles of education 75

proactive attitude 40

professional competence 100-1

proficiency 95-6

Pyhältö, K. 40

reading skills 47

realistic optimism 117

Reese, D. 50

reflective tutoring 80

Reivich, K. 117

rewarding work 104

Rosson, M. 50

Salmela, M. 120, 123

scheduling 47

Scheier, M. F. 40, 118

Schneider, S. L. 116-17

Seifert, T. A. 71

self-confidence 45

self-discipline 40

self-efficacy 31, 73 
self-fulfillment 41, 123, 126

self-motivation 117

self-reflection: in research 9 ; by students

29, 126; by supervisors 98

self-respect 45

Seligman, Martin 48, 82, 116, 118, 128

service philosophy 105

Shepperd, J. A. 119

Shugart, S. C. 120

Shulman, L. S. 28

Skrypnek, B. J. 121

Snyder, C. R. 100, 117

social capital: defining 50 ; and social media $50,54,56$

social issues 53

social life $34-5,49$

social media: benefits of 50-6; bonding and peer support through 52-3; and communality 54 ; information sharing through 53 ; and interactions $51-2,55$; as a learning environment $54-5$; marketing and communication through 53 ; and social capital 50,54 , 56 ; and social issues 53 ; and students 49-54; and well-being 50, 53-4

social network services (SNS) 9-10, 49-56; see also social media

social relationships: with families and friends 48 ; with peers $56-7$; and social capital 50 ; and student success 124-5; with teachers 55-7; through social media 50,54 ; in university community 101-2; with university personnel 57

social support 101-3

Soini, T. 40

solidarity $73-4$

sports 48

Starfield, Sue 95

Steinfield, C. 50

strength-based teaching 82-3

student engagement: and caring teacherhood 71-2; framework for $74-5$; and success 56,119

student interactions $51-2,55-7,80-1$, 87-90

student networks 55

students: and adjustment to academic studies 22; appreciation of opportunity by $45-6$; and collaboration 56-7; and community influence 20; courage of 46 ; as customers 74-5; enthusiasm of 46-7; expectations of 47; factors hindering progress of 19-23; and feedback 20, 127,129 ; hard work by 45 ; lack of community 23 ; loneliness of 23 ; and motivation 20, 123-4; patience of 46; reading skills 47 ; relationships of 25 ; scheduling by 47 ; self-confidence of 45 ; self-reflection of 29; self-respect of 45 ; and social media $49-53$; social relationships of 48 ; study skills of $19,21-2$; and teacher interactions 81; uncertainty by 47 ; unrealistic expectations of 19; well-being of 34 , $39,44,48,53,57$; writing skills 47 ; see also doctoral students

student success 103-4

student tutors 79

study activities 27

study attitudes 56

studying 26-7

study methods 124

study periods 24

study planning 79

study plans and scheduling 22-3

study process 19-20

study skills: deficiencies in 21-2; importance of 19

study success: and adjustment to academic studies 22 ; as a communal process 129; community influence on 20; conditions for 116; evaluation of 4 ; factors for $1-2,6,19-21$, 124-5; hindrances to 19-24; and hope 117-20, 125; and lack of community 23 ; and lack of guidance 23; and love of learning 120-2; meaningfulness in 56; and motivation 20; and overlapping courses 24; and peer support 5 ; and prior success 19,44 ; as a process and outcome 122-6; and self-reflection 126; and social relationships 124-5; and student commitment 129; student descriptions of 24-8; and student engagement 74-5; student resources for 44-9; and success at work 123-4, 127; and unclear directions 22; and well-being 5, 44, 116; see also success experiences

success: and competence 115; defining 115-16, 123; and development 126; expectations for 40-1; and hope 117-20; influences on 124; 
and love of learning 120-2; and meaningfulness 116; and motivation 115 ; and positive proactivity 116 ; and positive strategies 115,118 ; and student engagement 119; and wellbeing 116

success at work 115-16, 123-4, 127

success experiences: activities and practicums as 27; and flexibility $27-8$; good relationships as 25 ; and open university atmosphere 25-6; passing first exam as $24-5$; and positive feedback 28; studies and studying as 26-7; teachers and teaching as 26 supervision: caring 90-8; concreteness of 94 ; and constructive criticism 94; of doctoral theses 90-8; elements of 91-3, 95-8; and knowledge 93-4; and proficiency 95-6; protective and supportive factors of $96-7$; and self-reflection 98; and will 92-3; of writing 95-6

supervisors: and commitment 91 ; demands and expectations of 36 ; and doctoral students $35-7,44,90-8$; and feedback 37 ; roles of 90 ; and top performance 44

Sweeny, K. 119

\section{Takahashi, Y. 49}

teachers and professors: attitude of 89 ; as bellwethers 104-5; and challenges 99-100; and collaboration 98-9, 101-3; content knowledge of 29, 72 ; flourishing 103; and guidance 28 ; influence of 26,28 ; lecturing by 78; as mentors 55-6; pedagogical knowledge of 29; professionalism of 128 ; research by 28 ; and social support 101-3; and student interactions 81

teacher-training 1

teacher tutors 78-81

teaching: development of 5 ; inspiring 26; online 83-90; strength-based 82-3; university 2, 21; see also university education

teaching methods $77-8$

teaching skills 21 teamwork 56-7

Teramoto Pedrotti, J. 100

Theilheimer, R. 72

theory-led content analysis 8

time perception 43

togetherness 73-4

trust 73

tutoring: defining 78-9; emphases of 80 ; importance of 29,81 ; personal 80; reflective 80 ; student 79 ; student disappointment with 23,79 ; by teachers 78-9

typical performance 31

uncertainty 47

unclear directions 22

university community see academic community

university education 2, 21; caring in 71; curriculum planning in 21 ; equal access to 1,45 ; and garlands 48 ; open atmosphere of 25-6; resources for 4; sense of togetherness in 73-4; social network services (SNS) in 49-52

university entrance tests 19 university personnel 57

Uusiautti, S. 115

Vaarala, M. 49

Vansteenkiste, M. 126

virtual classrooms 89

Webropol questionnaire 6-7, 10

well-being: and achievement 116, 118; and education 119; and social capital 50; and social media 50, 53-4; and sports 48 ; in student life 48,57 ; and study processes 5,44 ; and success 5 , 44,116 ; and top performance 39 ; in university teachers' work 98

will 92-3

Wolniak, G. C. 71

work skills 57

writing skills 47,96

writing supervision 95-6

Wu, Crystal 48

Youngs, P. 103 